\title{
Tau Protein Interaction Partners and Their Roles in Alzheimer's Disease and Other Tauopathies
}

\author{
Jakub Sinsky, Karoline Pichlerova and Jozef Hanes * \\ Institute of Neuroimmunology, Slovak Academy of Sciences, Dubravska Cesta 9, 84510 Bratislava, Slovakia; \\ jakub.sinsky@savba.sk (J.S.); karoline.pichlerova@savba.sk (K.P.) \\ * Correspondence: jozef.hanes@savba.sk
}

Citation: Sinsky, J.; Pichlerova, K.; Hanes, J. Tau Protein Interaction

Partners and Their Roles in

Alzheimer's Disease and Other

Tauopathies. Int. J. Mol. Sci. 2021, 22, 9207. https://doi.org/10.3390/ ijms22179207

Academic Editor: Giuseppina Amadoro

Received: 2 August 2021

Accepted: 25 August 2021

Published: 26 August 2021

Publisher's Note: MDPI stays neutral with regard to jurisdictional claims in published maps and institutional affiliations.

\begin{abstract}
Tau protein plays a critical role in the assembly, stabilization, and modulation of microtubules, which are important for the normal function of neurons and the brain. In diseased conditions, several pathological modifications of tau protein manifest. These changes lead to tau protein aggregation and the formation of paired helical filaments (PHF) and neurofibrillary tangles (NFT), which are common hallmarks of Alzheimer's disease and other tauopathies. The accumulation of PHFs and NFTs results in impairment of physiological functions, apoptosis, and neuronal loss, which is reflected as cognitive impairment, and in the late stages of the disease, leads to death. The causes of this pathological transformation of tau protein haven't been fully understood yet. In both physiological and pathological conditions, tau interacts with several proteins which maintain their proper function or can participate in their pathological modifications. Interaction partners of tau protein and associated molecular pathways can either initiate and drive the tau pathology or can act neuroprotective, by reducing pathological tau proteins or inflammation. In this review, we focus on the tau as a multifunctional protein and its known interacting partners active in regulations of different processes and the roles of these proteins in Alzheimer's disease and tauopathies.
\end{abstract}

Keywords: tau protein; interaction partners; Alzheimer's disease; tauopathies

\section{Introduction}

Proteins are essential macromolecules that play important roles in almost any cellular process. They usually do not function alone but rather as complexes with other molecules, mainly with proteins. Protein-protein interactions (PPIs) are elementary for many processes and it is proposed that their dysfunction or deregulation is located upstream, leading to various pathological conditions [1]. In Alzheimer's disease and other tauopathies, tau protein undergoes pathological modifications that lead to the formation of paired helical filaments (PHF) and neurofibrillary tangles (NT) which belong to the main hallmarks of these diseases. The conversion of physiological tau into its pathological forms and their participation in disease etiology have not been fully understood yet and are still under investigation. In physiological conditions, tau interacts with many protein partners which maintain their proper structure and function. Under pathological conditions, proteins interacting with tau can also participate in its non-physiological modifications leading to the development of neurodegenerative diseases. Interaction partners of tau protein and involved molecular pathways can either initiate and drive the tau pathology or can have neuroprotective roles, by reducing pathological tau changes or inflammation.

Tau protein belongs to the family of microtubule-associated proteins (MAPs) [2,3] and can influence axonal transport and growth [4], neuronal polarization [5], and thus the normal function of neurons and the brain (Figure 1) [6,7]. 

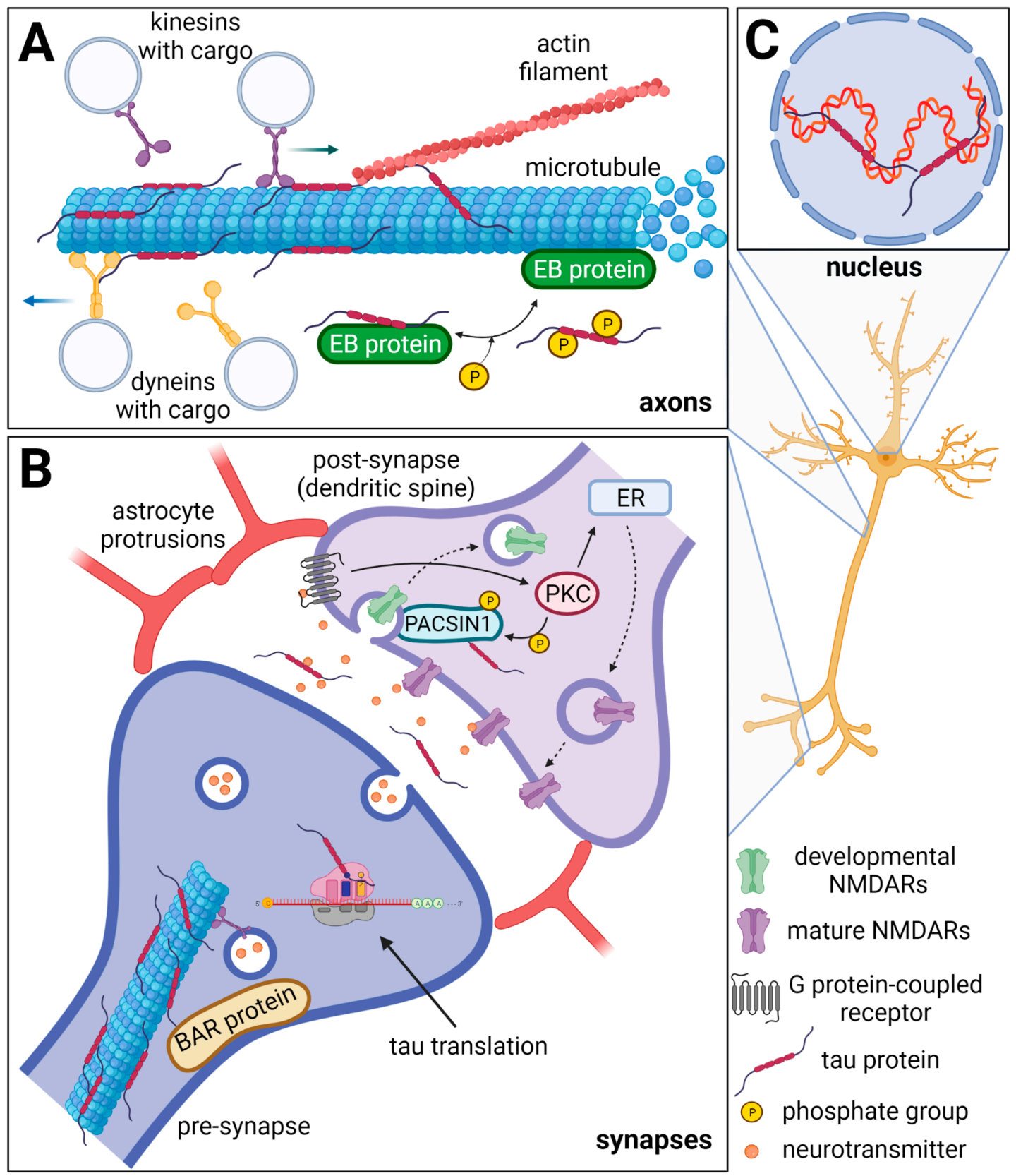

\section{mature NMDARs}

โ⿵⺆⿻二丨冂 $\mathrm{G}$ protein-coupled

receptor tau protein

\section{(P) phosphate group neurotransmitter}

Figure 1. Schematic representation of physiological tau protein functions in neurons. The axonal tau (A) stabilizes microtubules (MTs), and it can also bind actin filaments thus facilitating cytoskeleton networking. Furthermore, tau regulates MT dynamics by interacting with end-binding (EB) proteins. The EB proteins promote and regulate MT nucleation and elongation. Tau inhibits the EB protein binding to MTs and this inhibition is reversed by tau phosphorylation. Tau also competitively inhibits the interaction of dynein and kinesin to MTs and thus influences the intraneuronal transport and cargo release. In the synapses (B), tau protein can be directly translated, and during neuronal activity, it is released into the synaptic cleft. Through linking the MTs and actin filaments, tau can influence synaptic plasticity. Moreover, tau is a known interacting partner of the BAR domain-containing proteins such as BAIAP2, PACSIN1, and BIN1, that ensure the curvature and shaping of the neuronal membrane. Tau may play a role in the removal of developmental NMDARs and their replacement for mature NMDARs in dendrites (dashed arrows) as it is a known substrate of the protein kinase C (PKC), which is activated by the G protein-coupled receptors (GPCR). The PACSIN1 recruits clathrin and dynamin endocytic machinery to the developmental NMDARs and thus mediates their removal. The developmental/mature NMDARs exchange is important for the formation of new synaptic connections. ER-endoplasmic reticulum. In the nucleus (C), tau interacts with DNA and RNA, maintains their integrity, and protects them from oxidative damage. Furthermore, tau may be involved in rRNA-coding DNA transcription and rRNA processing. Created with BioRender.com. 
In humans, tau protein is expressed mainly in neurons [8], and in lower amounts in oligodendrocytes and astrocytes [9-12]. Besides the central nervous system (CNS), tau is expressed by peripheral neurons [13], and more recently, tau immunoreactivity was also found in the human submandibular gland and sigmoid colon tissues [14]. Human tau protein is encoded by MAPT gene localized on chromosome 17q21 and consists of 16 exons. In the adult human brain, six tau isoforms are expressed ranging from 352 to 441 amino acids (see Figure 2). Three decades ago, it was proposed that individual tau isoforms may have different functions since they are differently expressed in the fetal and developed brain [15-17]. Now, it is known that alternative splicing even varies across neuronal cell types and during neuronal maturation $[18,19]$.

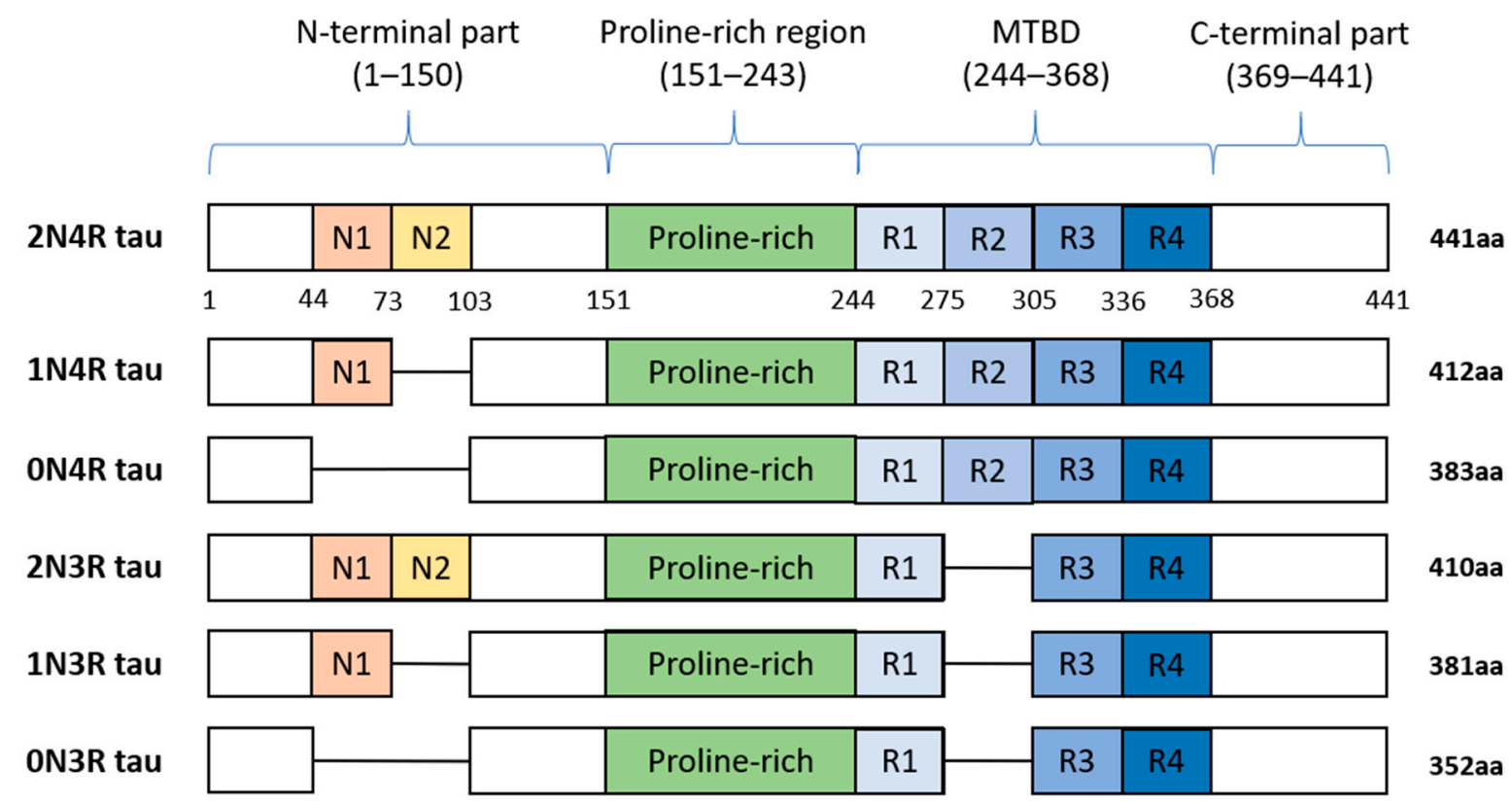

Figure 2. Schematic representation of six human tau protein isoforms and their domains. The N-terminal part is more acidic due to N1 and N2 inserts. The microtubule-binding domain (MTBD) is composed of repeats R1-R4. The number of repeats and $\mathrm{N}$-terminal inserts varies according to the type of tau protein isoform.

Tau protein is distinctly divided into the $\mathrm{N}$-terminal part, proline-rich region (PRR), microtubule-binding domain (MTBD), and C-terminus. The N-terminal domain length is dependent on alternative splicing of exons 2 and 3 which encode acidic amino acids. In MTBD, the splicing-dependent manner of exon 10 results in either $3(3 R)$ or $4(4 R)$ microtubule-binding repeats which are essential for binding of tau to individual tubulin heterodimers, and through this interaction tau stabilizes microtubules (MT) [20].

Despite the MT-stabilizing function of tau, its removal or modification had no significant impact on microtubule stability, cellular function, or cognition in mouse models [21-25]. It was shown that the MT-stabilizing function of tau protein is replaceable by microtubule-associated proteins MAP1a [22,26] or MAP1b [5]. However, experiments performed by several other groups on tau-knockout mice revealed that tau can influence the regulation of neuronal activity [27], synaptic plasticity [28], neurogenesis [29], iron export from neurons [30], and long-term depression of synapses [31,32]. Along with other animal disease models where the tau levels were reduced, it was found that depletion of tau protein had a protective effect on neurons against amyloid-beta $(\mathrm{A} \beta)$ induced excitotoxicity or by other excitotoxins in mice over-expressing amyloid precursor protein (APP) and presenilin 1 [33-37]. In chemically induced seizure models, hyperexcitability of neurons was reduced in mice with attenuated tau expression [38]. This suggests that endogenous tau is integral for regulating, or rather, upregulating neuronal hyperexcitability in diseased animals. In addition, in mice with impaired function of voltage-dependent sodium and 
potassium channels, the depletion of tau protein had a protective effect on neurons [39]. These studies suggest that tau protein may play a role in the regulation of neuronal network activity in both pathological and physiological conditions. Moreover, this is also supported by the evidence that tau protein has several additional roles in neurons and the brain [6].

In pathological conditions, the accumulation of insoluble tau aggregates occurs inside neurons, in extracellular space $[40,41]$, and other brain cells such as astrocytes and oligodendrocytes [42,43]. The formation of this stable material is the consequence of abnormally modified and truncated tau proteins which self-aggregate and gradually mature to paired helical filaments (PHF) and neurofibrillary tangles (NFT) which are common hallmarks of several neurodegenerative diseases [44]. The formation of PHFs and NFTs is associated with the engulfment of the cytosol of neurons, failure in intracellular trafficking, and gradual disruption of basic physiological processes that end in apoptosis and neuronal death [45-47]. The formation of these aggregates is accompanied by inflammation which on one hand could help in their clearance, but on the other, can exacerbate the pathological processes [48-50]. Tau pathology is the main cause of dementia in Alzheimer's disease and other neurodegenerative diseases, including frontotemporal dementia [51], argyrophilic grain disease [52], corticobasal degeneration [53,54], progressive supranuclear palsy [55], and several other diseases [44]. These disorders, where the accumulation of abnormal tau protein in the brain occurs, are referred to as tauopathies.

\section{Roles of Tau Protein in Physiology and Pathology}

\subsection{Tau and Axonal Transport}

Tau protein is enriched in axons where it binds microtubules through its MTBD and participates in their stabilization and regulation. Tau protein's "free" flanking N-terminal and C-terminal regions interact with various classes of proteins involved in the regulation of cytoskeleton $[56,57]$ and motor proteins kinesins and dyneins [58,59]. Thus, tau participates in the regulation of intraneuronal transport and modulation of microtubule dynamics, which ensures flexible reorganization of cytoskeleton and synaptic transmission. Tau can modulate functions of motor proteins by competitive inhibition of interactions of dynein and kinesin with microtubules, facilitating dynein binding to microtubules, or regulation of transport-vesicle releasing from motor proteins $[60,61]$.

\subsection{Tau Protein in Synapses}

Besides axons, tau protein occurs also in pre- and post-synapses and in smaller amounts also in dendrites [31-33]. Tau protein can be directly translated in synapses and this translation is regulated by synaptic activity [62]. Furthermore, synaptic activity mediates tau protein release into extracellular space including synaptic clefts [63-66]. When discussing tau in the neuronal synapse, it is important to mention that synapses are complex biological structures also comprising astrocytes. These physiological structures composed of neuronal synapses and astrocyte protrusions are referred to as tripartite synapses $[67,68]$. Through these protrusions, astrocytes maintain the proper function of synapses through astrocyte-lactate shuttle, glutamate and GABA uptake from the synaptic cleft, growth factors release, and other processes [69]. In tauopathies, tau protein aggregates damage these tripartite synapses and disturb the normal function of neuronal networks [70]. Furthermore, the microglia, which constantly scan the surroundings with their processes, interact regularly with synapses [71,72]. Along with the fact that tau proteins are released during synaptic activity under both, physiological and pathological conditions, the microglia themselves also can mediate the inter-cellular spreading of the tau protein [73]. Released extracellular tau could be capable of interactions with proteins present in the synaptic clefts, thus influencing synaptic functions.

The structure of synapses is determined by the actin filaments, microtubules, and proteins modulating the membrane shape. It was shown that tau can mediate changes in the dendritic cytoskeleton and regulate synaptic plasticity and signaling [74,75]. Tau protein is known to interact with proteins regulating cytoskeleton and membrane curvature 
which are essential for synapse formation and sustainability [56,76-79]. Tau binds actin via its PRR, and at the same time also binds microtubules through its MTBD and serves as a crosslinker between microtubules and actin filaments and thus helps to organize the cytoskeleton network [20,80,81]. Furthermore, tau regulates the function of synaptic and extrasynaptic NMDA receptors (NMDARs) which mediate $\mathrm{Na}^{+}$and $\mathrm{Ca}^{2+}$ influx into neurons and regulate membrane polarization [82].

\subsection{Tau Protein in the Nucleus of Neurons}

Tau is localized in the nucleus of neurons, more precisely, in nucleolar organized regions of the nucleolus [83-86]. Since nucleolus is the center of ribosomal RNA (rRNA) synthesis and processing, several studies which described localization of tau in parts of nucleolus suggest that tau can be involved in rRNA-coding DNA transcription and rRNA processing [86,87]. Tau can directly bind DNA [88] and RNA [89] and protects them from oxidative damage $[90,91]$ which helps to maintain DNA and RNA integrity [92]. Furthermore, tau-DNA interaction is modulated by tau phosphorylation, which strongly reduces the ability of tau to bind DNA [93]. Hyperphosphorylation, which is one of the major hallmarks of the pathological forms of tau, may also influence its nucleocytoplasmic transport. According to the recent study, hyperphosphorylated tau directly interacts with a subunit of nuclear pore complex-nucleoporin NUP98 causes its mislocalization and disrupts the nucleocytoplasmic transport [94].

\subsection{Big Tau}

Big tau was initially known from studies on rats and mice where tau proteins were detected in their tissues, as well as, in cell lines derived from these species. This highmolecular-weight form of a rat and murine tau has an apparent molecular weight of $\sim 110 \mathrm{kDa}$ and possesses 733 or 752 amino acids (aa), respectively [95,96], as a result of the involvement of exon $4 \mathrm{a}$ and alternatively spliced exon 6 of MAPT gene in its transcript $[97,98]$. It was shown that Big tau is expressed only in the peripheral nervous system (PNS), neurons of the optic nerve, but also in specific CNS neurons with long axons projecting to the periphery $[96,99]$. In human sequence databases, Big tau is also designated as the PNS tau. Human Big tau (Figure 3) has not been confirmed experimentally in human tissues or human-derived cell lines so far, and its specific function remains unanswered. In light of the known functions of brain tau protein, several benefits of Big tau due to its increased length were proposed. The most important is the increased spacing between microtubules observed in processes of Sf9 cells overexpressing Big tau, which may reduce the energy required for axonal transport [100]. Furthermore, the elongated N-terminus of Big tau was proposed to reduce the rate of phosphorylation of motor proteins, and not mitigating their activity, thus supporting uninterrupted axonal transport $[97,101]$.

\begin{tabular}{|c|c|c|c|c|c|c|}
\hline $\begin{array}{l}\text { Human } \\
\text { Big tau }\end{array}$ & $\begin{array}{c}\mathrm{N} \text {-terminal part } \\
(1-460)\end{array}$ & & $\begin{array}{l}\text { Proline-rich regi } \\
\text { (461-559) }\end{array}$ & & $\begin{array}{c}\text { MTBD } \\
(560-685) \\
\end{array}$ & $\begin{array}{c}\text { C-terminal part } \\
(686-758)\end{array}$ \\
\hline \begin{tabular}{|l|l|} 
N1 & N2
\end{tabular} & Exon 4a & Exon 6 & Proline-rich & R1 & \begin{tabular}{l|l} 
R2 & R3
\end{tabular} & R4 \\
\hline
\end{tabular}

Figure 3. Schematic representation of human Big tau. Its counterparts in rat and mouse possess 752 or 733 aa and share $74.9 \%$ or $74.2 \%$ identity, respectively. Exons $4 \mathrm{a}$ and 6 are responsible for differentiation from the brain tau protein.

\subsection{Extracellular Tau Protein}

Mounting evidence shows that pathological forms of tau protein spread from diseased to healthy cells and transform physiological tau to its misfolded pathological forms which in turn self-aggregate and form PHF and NFT [102,103]. It was shown that neuronal activity, accompanied by synaptic transmission, mediates tau protein release into extracellular space, mainly in an exosome-bound form, but also in a soluble form, and that this process 
occurs under both physiological and pathological conditions [63-66]. One of the suggested pathways of pathological tau spreading is connected to the resident macrophages of CNSmicroglia [73]. Microglia have both phagocytic and secretion properties and can play a key role in the spreading of tau pathology [104]. Microglial exosomes serve as a medium for intercellular transport of cytokines, miRNAs, and other regulating factors [105]. The fact that microglia can be involved in the spreading of pathological tau forms is supported by several experiments. The group of Asai showed that depletion of the microglia in mouse brain significantly slowed propagation of tau between cells and that tau spreading was mediated by microglial exosomes [106]. Another research group demonstrated that reactive, inflammatory microglia can contribute to the spreading of tau pathology [73].

\section{Tau Interaction Partners (TIPs), Their Biological Functions and Related Molecular Pathways}

The understanding of tau function and behavior is mainly based on genetic experiments such as in-site mutagenesis, overexpression, or depletion of tau protein in animal or cellular models [107-109]. Moreover, studying physical protein-protein interactions [PPIs] significantly broadened the knowledge about tau protein function and its relationship to various physiological processes [7]. Since PPIs are elementary for many processes and it is supposed that their dysfunction or deregulation is located upstream of various pathological conditions, it is important to understand the tau protein interactome and dynamics [1].

Studies that focused on tau protein forms present in PHF and NFT showed that tau present in pathological lesions can be phosphorylated, truncated, glycosylated, nitrated, and ubiquitinated [110-117]. Therefore, it is likely that proteins involved in molecular pathways connected to the above-mentioned posttranslational modifications can have an impact on the pathological processes in tauopathies. The proteins and other compounds identified in NFT are listed in Table 1. Their presence in NFT could be the consequence of their physiological or pathological interactions with tau [118-120]. However, their presence in NFT can also result from a damaged fine-balanced chaperone system, altered nature of individual proteins due to pathological conditions (oxidation, modifications, etc.), or nucleocytoplasmic coagulation of proteins [121].

Table 1. Overview of proteins and substances found mounted in paired helical filaments and neurofibrillary tangles.

\begin{tabular}{|c|c|c|}
\hline Category & Proteins/Substances & Reference \\
\hline \multirow{5}{*}{ Tubulin interacting proteins } & microtubule-associated protein 2 & {$[122]$} \\
\hline & microtubule-associated protein 1B & {$[123,124]$} \\
\hline & neurofilament proteins, vimentin & {$[125]$} \\
\hline & heparansulfate proteoglycans & {$[126,127]$} \\
\hline & amyloid precursor protein & {$[128,129]$} \\
\hline \multirow{4}{*}{$\begin{array}{l}\text { Kinases and other cytosol } \\
\text { enzymes }\end{array}$} & casein kinase II & {$[130]$} \\
\hline & extracellular signal-related kinase-2 & {$[131]$} \\
\hline & glycogen synthase kinase- 3 & {$[132]$} \\
\hline & phospholipase C- $\delta$ & {$[133]$} \\
\hline \multirow{3}{*}{ Stress molecules } & advanced glycation end products & {$[134-136]$} \\
\hline & malondialdehyde & {$[137]$} \\
\hline & heme oxygenase-1 & {$[136]$} \\
\hline \multirow{3}{*}{$\begin{array}{l}\text { Amyloid and amyloid-binding } \\
\text { proteins }\end{array}$} & complement proteins (Clq, C3, C4d and C5b-9) & {$[138,139]$} \\
\hline & vitronectin & [140] \\
\hline & apolipoprotein-E & {$[141,142]$} \\
\hline
\end{tabular}


Table 1. Cont.

\begin{tabular}{lll}
\hline Category & Proteins/Substances & Reference \\
\hline \multirow{4}{*}{ Others } & C-series of gangliosides & {$[124]$} \\
\cline { 2 - 3 } & ubiquitin and ubiquitin ligases & {$[143-145]$} \\
\cline { 2 - 3 } & synaptophysin & {$[146]$} \\
\cline { 2 - 3 } & anti-thrombin III & {$[147]$} \\
\cline { 2 - 3 } & lactotransferrin & {$[148]$} \\
\hline
\end{tabular}

Physiological IPs play different roles in cells, and they are a part of various molecular pathways like energy metabolism, chaperone complex, apoptosis, organization of the cytoskeleton, and signaling pathways. Under pathological conditions, abnormal interactions of tau with its partners may occur as a consequence of the deregulation of any molecular pathway. Vice versa, newly emerging pathological forms of tau proteins within the cell can deregulate or block physiological processes in the cell and interact with proteins that do not occur under physiological conditions.

PPIs are summarized in several databases, however, all of them contain many hypothetical, predicted, or experimentally non-validated interactions. The following PPI databases are the best known (with the number of Homo Sapiens interactions in brackets): BioGRID (789073) [149], GPS-Prot (395501) [150], DIP (9141) [151], IntAct (703717) [152], MINT (10143) [153], STRING (12628534) [154] and IID (1099176) [155]. We reviewed all of them and found that the BioGRID (Biological General Repository for Interaction Datasets) was the most representative regarding TIPs (reporting up to date 245 TIPs). After a detailed review of all listed studies reporting the interactions, we excluded the non-validated interaction partners, which were derived mainly from large-scale interaction studies with no additional validation experiments. We then examined the resulting 153 experimentally validated TIPs by reviewing the scientific literature and protein databases. TIPs can be divided into several groups according to their molecular functions and their impact on tau protein physiology and pathology (Figure 4).

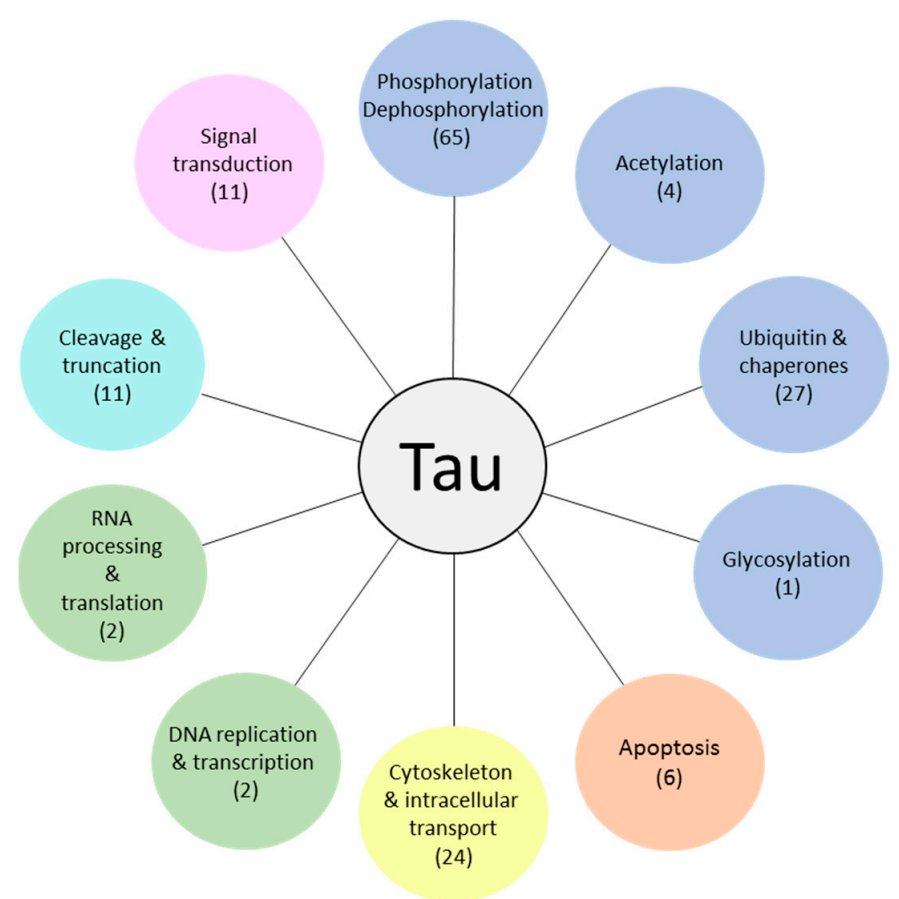

Figure 4. Overview of validated TIPs distributed according to their function. In brackets: the number of validated TIPs for the particular group. 


\subsection{Tau as a Substrate for Kinases and Phosphatases}

Phosphorylation and dephosphorylation of tau protein are physiological processes that regulate the binding of tau to microtubules. Increased phosphorylation of tau MTBD causes the release of tau from microtubules [116,156-159]. Under pathological conditions, tau protein is hyperphosphorylated, unable to bind microtubules, and subsequently aggregates and forms PHF and NFT. In AD, several pathological phosphorylations were identified [117,160-164], and the overall phosphorylation of tau is elevated by approximately four-fold in comparison to a healthy brain. This ratio may be even higher due to postmortem delay of analyzed brain samples where tau dephosphorylation by phosphatases occurs $[116,165]$. The longest isoform of human tau protein has 85 potential phosphorylation sites of which 71 were experimentally documented [160,163,166-168]. This represents $19.3 \%$ of tau amino acids available for phosphorylation/dephosphorylation.

Among the known, and validated TIPs, 65 of them are involved in phosphorylation and /or dephosphorylation. Fifty-four of them are protein kinases (Table 2), seven phosphatases (Table 3), and four important kinase or phosphatase modulating proteins (Table 4). The protein kinases, which represent the majority of TIPs, were extensively reviewed by Martin et al. [169] and partially by Guo et al. [18]. The phosphatases, including PP2A, which contributes to approximately $70 \%$ of brain dephosphorylation activity [170], were deeply reviewed in Martin et al. [171] and by Guo et al. [18].

Table 2. Overview of protein kinases interacting with tau protein and their roles in pathology.

\begin{tabular}{|c|c|c|}
\hline Protein & Roles in Tau Pathology & References \\
\hline ABL1 & involved in formation of apoptotic complex & [172] \\
\hline AKT1 & $\begin{array}{l}\text { neuroprotective activity; inactivates pro-apoptotic proteins and } \\
\text { promotes cell survival }\end{array}$ & [173] \\
\hline BRSK $(1,2)$ & unknown role in tau pathology & - \\
\hline CAMK2A & involved in hyperphosphorylation of tau in $\mathrm{AD}$ & {$[174,175]$} \\
\hline CDK $(1,5)$ & $\begin{array}{l}\text { accelerate tau hyperphosphorylation and formation of NFT; act } \\
\text { neuroprotective by apoptosis inhibition }\end{array}$ & {$[176,177]$} \\
\hline CDK2 & $\begin{array}{l}\text { inhibits tau-mediated tubulin polymerization by tau } \\
\text { phosphorylation }\end{array}$ & [178] \\
\hline CSNK1 (A1, D) & $\begin{array}{l}\text { involved in formation of } A \beta \text {; colocalize with NFT, suggesting a } \\
\text { role in tau aggregation }\end{array}$ & {$[179,180]$} \\
\hline DYRK1A & $\begin{array}{l}\text { overexpressed in AD; facilitates further tau phosphorylation by } \\
\text { GSK3B }\end{array}$ & {$[181,182]$} \\
\hline DYRK2 & overexpressed in $\mathrm{AD}$; involved in activation of apoptosis & {$[181,183]$} \\
\hline FYN & $\begin{array}{l}\text { facilitates formation of NFT by tau hyperphosphorylation; } \\
\text { activates PTK2B; potentiates A } \beta \text {-induced synapse damage }\end{array}$ & [184-186] \\
\hline GSK3 (A, B) & $\begin{array}{l}\text { responsible for hyperphosphorylation of tau; involved in } \\
\text { activation of apoptosis; exacerbate tau pathology when activated } \\
\text { by A } \beta\end{array}$ & [187-189] \\
\hline $\operatorname{CHEK}(1,2)$ & unknown role in tau pathology & - \\
\hline LCK & it is downregulated in $\mathrm{AD}$; unknown role in tau pathology & {$[190,191]$} \\
\hline LRRK2 & $\begin{array}{l}\text { contradictory reports: enhances abnormal tau phosphorylation } \\
\text { and promote tauopathy or, no impact on tau pathology was } \\
\text { shown }\end{array}$ & [192-195] \\
\hline
\end{tabular}


Table 2. Cont.

\begin{tabular}{|c|c|c|}
\hline Protein & Roles in Tau Pathology & References \\
\hline MAP2K7 & $\begin{array}{l}\text { colocalize with hyperphosphorylated tau; contribute to } \mathrm{A} \beta \\
\text { accumulation }\end{array}$ & {$[196,197]$} \\
\hline MAPK $(1,3,8-14)$ & overactivated in AD; involved in abnormal tau phosphorylation & {$[198,199]$} \\
\hline MARK (1-3) & phosphorylate tau aggregates; colocalizes with NFT & [200] \\
\hline MARK4 & $\begin{array}{l}\text { phosphorylate tau aggregates; mutation causes tau } \\
\text { hyperphosphorylation, aggregation and tau-mediated } \\
\text { neurodegeneration; colocalizes with NFT }\end{array}$ & {$[200,201]$} \\
\hline PHKG1 & unknown role in tau pathology & - \\
\hline PKN1 & regulates tau phosphorylation; colocalize with NFT & [202,203] \\
\hline PRKACA & $\begin{array}{l}\text { abnormally phosphorylate } \alpha \text {-Synuclein-bound tau; facilitates } \\
\text { further phosphorylation of tau by GSK3 kinase; colocalize with } \\
\text { NFT; important for regulation of alternative splicing of exon } 10 \text { in } \\
\text { MAPT }\end{array}$ & [204-207] \\
\hline PRKC (A, B, E, G, I, Z) & $\begin{array}{l}\text { neuroprotective role through inhibition of GSK3 kinase and } \\
\text { reduced tau phosphorylation }\end{array}$ & {$[208,209]$} \\
\hline РTK2B & $\begin{array}{l}\text { hyperphosphorylates tau; is regulated by FYN kinase; colocalize } \\
\text { with pathological tau proteins in brains of AD patients }\end{array}$ & {$[185,210]$} \\
\hline RPS6K (A1, A3, A5, B1) & $\begin{array}{l}\text { their attenuation is neuroprotective; possibly upregulate tau } \\
\text { translation; contribute to tau aggregation and synapse damage; } \\
\text { inhibit apoptosis }\end{array}$ & [211-213] \\
\hline SGK1 & $\begin{array}{l}\text { upregulated in AD; enhances tau hyperphosphorylation by } \\
\text { GSK3B activation }\end{array}$ & [214] \\
\hline SIK1 & unknown role in tau pathology & - \\
\hline SRC & unknown role in tau pathology & - \\
\hline $\operatorname{SRPK}(1,2)$ & $\begin{array}{l}\text { involved in regulation of alternative splicing of exon } 10 \text { in MAPT, } \\
\text { where impaired splicing of exon } 10 \text { can lead to tauopathy }\end{array}$ & {$[215,216]$} \\
\hline SYK & $\begin{array}{l}\text { accumulation of pathological tau proteins cause overactivation of } \\
\text { SYK, which further hyperphosphorylates tau and exacerbate } \\
\text { pathology; contributes to the neuroinflammation; inhibits } \\
\text { autophagic tau degradation; contributes to neuronal loss }\end{array}$ & [217-219] \\
\hline TTBK1 & $\begin{array}{l}\text { enhances tau phosphorylation and aggregation; involved in } \\
\text { neurodegeneration }\end{array}$ & {$[220,221]$} \\
\hline
\end{tabular}

Table 3. Overview of protein phosphatases interacting with tau protein and their roles in pathology.

\begin{tabular}{lll}
\hline Protein & Roles in Tau Pathology & References \\
\hline PPP1C (A, B, C) & $\begin{array}{l}\text { downregulated in AD; neuroprotective function by reducing } \\
\text { hyperphosphorylated tau levels; }\end{array}$ & {$[170,222]$} \\
\hline PPP2C (A, B) & $\begin{array}{l}\text { downregulated in AD what induces tau hyperphosphorylation; } \\
\text { neuroprotective; regulate autophagic degradation of proteins }\end{array}$ & {$[170,222-224]$} \\
\hline PPP5C & $\begin{array}{l}\text { downregulated in AD what contributes to increased levels of } \\
\text { hyperphosphorylated tau; dephosphorylates AD phospho-tau; } \\
\text { protects against A } \beta \text { toxicity }\end{array}$ & {$[225-227]$} \\
\hline PTPN11 & upregulated in AD; unknown role in tau pathology & {$[228]$} \\
\hline
\end{tabular}


Table 4. Overview of proteins participating in the regulation of kinases or phosphatases known to interact with tau protein and their roles in pathology.

\begin{tabular}{lll}
\hline Protein & Roles in Tau Pathology & References \\
\hline PTPA & $\begin{array}{l}\text { regulatory subunit of PPP2C (A, B); decreased expression in AD; enhances } \\
\text { tau dephosphorylation; neuroprotective; regulate autophagic degradation } \\
\text { of proteins }\end{array}$ & {$[223,224,229,230]$} \\
\hline CDC37 & $\begin{array}{l}\text { regulates tau phosphorylation, enhances phospho-tau stability at HSP90 } \\
\text { scaffold, preventing its degradation, preserves CDK5 and AKT kinases }\end{array}$ & {$[231]$} \\
\hline PIK3R1 & $\left.\begin{array}{l}\text { key unit of PI3K, part of the PI3K/AKT1/GSK3B signaling pathway, which } \\
\text { is downregulated in AD, plays a role in insulin signaling pathway where it } \\
\text { might exacerbate AD pathology }\end{array}\right]$ [232-235] & $\begin{array}{l}\text { inhibits tau phosphorylation; enhances tau dephosphorylation by PPP5C; } \\
\text { overexpression of S100B causes apoptosis, tau hyperphosphorylation, and } \\
\text { inflammation }\end{array}$ \\
\hline
\end{tabular}

\subsection{Tau-Interacting Partners Involved in Acetylation and Deacetylation of Proteins}

Acetylation affects around $80-90 \%$ of all translated human proteins [241]. Acetylases are enzymes with acetyltransferase and deacetylase activity, and their role is the addition or removal of an acetyl group to the N-terminal or lysine residues of proteins. Acetylation of proteins regulates many processes, for example, transcription and memory consolidation by histone acetylation [242,243], localization in the cell [244], modulation of PPIs, and others [245]. Acetylation of tau protein on the $\mathrm{Lys}^{280}, \mathrm{Lys}^{281}$, and $\mathrm{Lys}^{311}$ residues impairs tau binding to microtubules [246,247], which leads to increased pools of cytosolic tau available for pathological aggregation. Tau itself possesses intrinsic acetyltransferase activity that allows tau self-acetylation [248]. Tau acetylation occurs before tau fibrillization into PHF suggesting that it could be an upstream pathological event. Besides AD, acetylated tau at the Lys ${ }^{280}$ is also present in PHF from patients with corticobasal degeneration [247]. In $\mathrm{AD}$, deregulation of acetylation of both nuclear and cytoplasmic non-histone proteins occurs. Acetylated-tau is present through all of the stages of AD, peaking in the end stages of the disease [249]. Moreover, acetylation of tau inhibits its degradation, and along with increasing the concentration of unbound tau, it contributes to tau aggregation and pathology [250].

Currently, four proteins acetylases are validated as TIPs: CREB-binding protein (CBP) [251], histone acetyltransferase p300 (p300 HAT) [246,250,252], NAD-dependent protein deacetylase sirtuin-1 (SIRT1) [250] and histone deacetylase 6 (HDAC6) [253].

CBP and p300 HAT are highly homologous enzymes, which regulate transcription via chromatin remodeling and also acetylate non-histone proteins [247,254,255]. Both enzymes can acetylate up to 19 sites in tau protein located in the PRR and MTBD. The loss or overexpression of CBP and p300 HAT is responsible for neuronal death, which suggests that only the balanced and specific activity of these acetyltransferases is neuroprotective [256].

HDAC6 is a deacetylase mainly found in the cytoplasm, but also in smaller amounts in the nucleus [257]. Its main function is the deacetylation of several cytoplasmic proteins. Under pathological conditions, the HDAC6 is overexpressed, along with increased translocation to the nucleus, resulting in a decreased levels of brain-derived neurotrophic factor, a critical factor for synaptic repair and plasticity, leading to synaptic loss [258]. The overexpression of HDAC6 in AD can result in lower levels of acetylated tubulin [253], and thus impairment of transport, or increase in oxidative stress by deacetylation of peroxyredoxins resulting in lowering their ability to eliminate oxidative response products [259]. Furthermore, overexpression of HDAC6 elevates the burden of tau [260], which might also play a role in neuroinflammation [261,262]. HDAC6 can also deacetylate lysine residues in MTBD of tau which enhances tau phosphorylation, and aggregation [252].

The deacetylase SIRT1 links transcriptional regulation to the energy homeostasis of the cell. It plays a role in different processes like cell cycle, response to DNA damage, 
metabolism, apoptosis, and autophagy [263,264]. The expression of SIRT1 is decreased in aged neurons, and under neuropathological conditions $[265,266]$. SIRT1 deacetylates lysine residues in the PRR of tau protein [250] and has a neuroprotective role during neuronal injury and neurodegeneration [267]. Deletion of the Sirt1 gene in the mouse model of tau exacerbated their mortality, synapse loss, and cognition deficits. After induced expression of Sirt1 in the same model, the spread of tau pathology in the brain was attenuated [268]. In AD, SIRT1 levels are decreased and negatively correlated with the accumulation of pathological tau acetylated at Lys ${ }^{174}$ [265]. Deficiency of SIRT1 leads to synapse loss, impaired memory and spatial learning [269], elevated levels of proinflammatory cytokines, and accumulation of hyperphosphorylated tau due to low tau turnover [250]. Thus, the interaction of SIRT1 with tau protein has neuroprotective effects.

\subsection{Tau-Interacting Partners Involved in Glycosylation}

Only one protein from this group was experimentally validated for interaction with tau: the O-linked $N$-acetylglucosamine transferase (OGT) [270]. OGT is a glycosyltransferase that catalyzes the addition of a $\beta-N$-acetylglucosamine (GlcNAc) moiety to threonine or serine residues via an $O$-glycosidic linkage [271]. In a healthy brain, the tau phosphorylation sites are protected by $\mathrm{O}-\mathrm{GlcNAc}$ modification. Thus, a competitive modification of Ser and Thr residues between $\mathrm{O}-\mathrm{GlcNAcylation}$ and phosphorylation occurs. In vitro glycosylation of tau at Ser $^{356}$ slowed tau aggregation [272]. In AD, impaired glucose metabolism leads to the reduction of UDP-GlcNAc, thereby decrease in O-GlcNAc levels, thus facilitating the tau phosphorylation and aggregation [273,274]. After the phosphorylation of tau, the chance of tau being O-GlcNAcylated is lower [275].

\subsection{Interactions of Tau with Ubiquitin-Proteasome System and Chaperone System}

Two major degradation pathways are known: the ubiquitin-proteasome and the lysosomal pathway, and these pathways are tightly regulated with molecular chaperones [276]. It is proposed that a fine-balanced chaperone system, which participates in correct protein folding and degradation of misfolded proteins could play an important role in the accumulation of disordered toxic tau species. Indeed, it has been shown that the chaperone system is impaired in tau pathology [277]. However, it is unclear whether this event is upstream or downstream of tau pathology.

\subsubsection{Tau-Interacting Proteins Involved in the Ubiquitin-Proteasome Pathway}

The ubiquitin-proteasome pathway of protein degradation involves the attachment of ubiquitin moieties to proteins which ensures their targeting to proteasomal degradation [278]. The process of ubiquitination starts by activation of ubiquitin by ubiquitin-activating enzymes (E1). Subsequently, the activated ubiquitin is transferred to a ubiquitin-conjugating enzyme (E2) and then attached to the target protein by ubiquitin ligases (E3) [279]. Some of the experimentally detected E2 ubiquitin-conjugating enzymes (UBE) interacting and ubiquitinating tau protein are UBE2D2 [280], UBE2D3 [281], and UBE2W [280-283]. The UBE2W is likely specific to intrinsically disordered proteins, such as tau, because of its partly disordered and flexible C-terminal domain. This flexibility allows recognition of disordered N-terminal domains of proteins and promotes ubiquitination [284].

One of the E3 ubiquitin-protein ligases that interact and modify tau proteins is parkin $[285,286]$. Parkin regulates mitochondrial trafficking, mitophagy, endosomal sorting, synaptic transmission, programmed necrosis, ER stress, inflammation, and cellular homeostasis [287-290]. Despite its various important cellular processes, there is not enough evidence about its direct involvement in tau pathology.

Other E3 ubiquitin-protein ligases reported to interact with tau are CHIP [281,291], axotrophin [292], and TRAF6 [293]. The CHIP ligase targets misfolded chaperone substrates to proteasomal degradation [294], and along with HSP70 chaperones, facilitates ubiquitination and degradation of tau protein which enhances cell survival [280]. Studies 
show that CHIP overexpression can promote tau aggregation [285], and ubiquitination of tau by axotrophin significantly reduces the affinity of tau protein to microtubules [292].

E3 ubiquitin-protein ligase TRAF6 acts in cooperation with Sequestosome-1 (SQSTM1) via complex formation. SQSTM1 is a multifunctional TIP [293,295] that regulates the elongation of ubiquitin chains on the surface of substrates and intensifies their targeting signal [296-298]. The SQSTM1 is essential for the shuttling of tau to proteasomal degradation because TRAF6 alone is not capable to polyubiquitinate tau [293]. Furthermore, SQSTM1 also functions as a receptor for selective macroautophagy of polyubiquitinated proteins and aggregates $[299,300]$.

The neddylation is a process similar to ubiquitination; however, instead of ubiquitin, the NEDD8 is attached to proteins [301]. NEDD8 by itself and its protein conjugates are targeted to proteasomal degradation by NEDD8 ultimate buster 1 (NUB1), which was also identified as a tau-interacting protein [302,303]. The work of Richet et al. [303] showed that in SK-N-SH cells, NUB1 disrupts the interaction of tau with GSK3 $\beta$ kinase thus lowering pathological phosphorylation and aggregation of tau. The same group also recently showed that SQSTM1 specifically interacts with NUB1. Using the SH-SY5Y neuroblastoma cell model, it was demonstrated that NUB1 reduced the levels of insoluble tau aggregates. NUB1 also increased the autophagy-lysosomal pathway which facilitated the release of tau from SH-SY5Y cells [304]. These data suggest that NUB1 enhances the viability of diseased neurons at the expense of facilitating tau spreading between cells.

\subsubsection{Tau-Interacting Proteins Involved in Chaperone System}

The chaperone system is composed mainly of heat shock proteins (HSPs), which are involved during stress conditions. These proteins mainly function as molecular chaperones and regulate several diverse cellular processes, including protein folding, targeting, transport, degradation, and signal transduction. Under stress conditions, they assist in protein refolding and suppress aggregation, which promotes the maintenance of cellular homeostasis. HSPs are classified into the following families according to their molecular size: HSP90, HSP70, HSP60, HSP40, and small HSPs.

HSP70 chaperones assist in the stabilization and folding of many substrates and are found in most cellular compartments [305]. In humans, 11 genes encoding HSP70 family members have been identified [306]. The four chaperones of this family are known to interact with tau: HSPA1A [307], HSPA4 [307], HSPA5 [308] and HSPA8 [309]. All HSP70 proteins have a conserved N-terminal ATPase domain that binds and hydrolyses ATP and a C-terminal substrate-binding domain. The co-chaperone of HSP70, BAG family molecular chaperone regulator 1 (BAG1), serves as a nucleotide-exchange factor and promotes the release of ADP from HSP70 chaperones [310]. BAG1 was also found to interact with tau; however, only in complex with HSP70. Despite this indirect interaction, BAG1 is an important regulator in tau pathology because of its inhibitory effect on ubiquitinindependent 20S proteasomal degradation [311]. However, HSP70 chaperones are potent inhibitors of tau aggregation by preventing the formation of tau oligomers and PHF. It has been shown that HSP70 chaperones protect neuronal functions against the toxic effects of tau aggregates and oligomers [312].

Another co-chaperone of HSP70s interacting with tau is the DnaJ homolog subfamily A member 1 (DNAJA1). It was demonstrated that the over-expression of DNAJA1 mediated ubiquitin-dependent clearance of tau, while DNAJA1 knockdown facilitated tau accumulation [313].

The HSP90 heat shock protein family is an essential component of the eukaryotic cytosol where they stabilize misfolded proteins and regulate the activity of various signaling proteins, including steroid hormone receptors, tyrosine kinases, nitric oxide synthase, and calcineurin [314]. Two HSP90 proteins are known to interact with tau: HSP90 $\alpha$ [315-317] and its co-chaperone and activator AHSA1 [318], which triggers the ATPase activity of HSP90 $\alpha$ thus increasing its activity [319]. The interaction of tau with both these proteins 
is pathological. HSP90 and its activator AHSA1 can mediate tau oligomerization and aggregation [320-322].

Heat shock protein $\beta-1$ (HSPB1), which belongs to the family of small HSPs, preferentially interacts with hyperphosphorylated tau in the human brain [323]. In the cell model, it decreased hyperphosphorylated tau levels, increased the abundance of dephosphorylated tau, and suppressed tau-mediated cell death [324].

The Clusterin (CLU) is a chaperone that prevents the aggregation of misfolded proteins [325]. It is present in two main forms: the secreted (sCLU) and intracellular (iCLU). Total levels of both sCLU and iCLU are significantly increased in AD, and these levels are proportional to overall levels of insoluble $A \beta$ and tau aggregates [326]. iCLU was identified as a TIP, which also interacts with another TIP: BIN1 (see Section 3.7). It was shown that expressions of both iCLU and BIN1 were associated with misfolded tau in $\mathrm{AD}$ [327]. Expression of certain coding CLU variants linked to AD risk led to increased levels of iCLU. Therefore, the iCLU and BIN1 interaction might impact Tau function in neurons, and could be involved in the etiology of tau pathology in AD.

Protein isomerization is an essential physiological process involved in protein folding and maturation [328]. Two types of isomerization in proteins are known: prolyl cis-trans isomerization and disulfide isomerization. The prolyl cis-trans isomerization shifts the proline peptide bonds between cis and trans conformation, thus causing changes in protein secondary structure [329]. The 2N4R tau contains 43 proline residues, the majority of which are located in its PRR. Thus, isomerization of the proline peptide bonds between cis-trans conformation can influence tau protein structure and behavior [330,331]. Moreover, the proline cis-trans isomerization also regulates tau protein phosphorylation. Deregulation of this process causes phosphorylation of tau protein at AD-specific phospho-sites [332].

Five peptidyl-prolyl cis-trans isomerases: FKBP1A [315], FKBP4 [333], FKBP5 [318], PIN1 [334], cyclophilin D (CypD), and one protein disulfide-isomerase (PDI), are known to interact with tau. PDI is responsible for proper protein folding by both enzymatic and chaperone activity. It catalyzes the rearrangement of the formed disulfide bonds to correct positions [335]. It was shown that tau aggregation is significantly prevented by the binding of PDI to monomeric tau proteins [336]. Furthermore, the PDI strongly inhibits the tau seeding process which precedes tau aggregation $[337,338]$. In AD, PDI is S-nitrosylated which causes inhibition of this enzyme [339,340].

The peptidyl-prolyl cis-trans isomerases play an important role in protein folding through the isomerization of proline peptide bonds between cis and trans conformation. Their functional effects on tau protein and related pathology were extensively discussed in reviews of Blair et al. [341] and Peak et al. [342]. They play different roles in tau pathology, they can either facilitate tau aggregation, like FKBP4 and FKBP5, or can be neuroprotective, like PIN1 or FKBP12.

Cyclophilin D (CypD) [343], besides its peptidyl-prolyl activity, also participates as a regulator of the mitochondrial permeability transition pore in mitochondria, which is responsible for the $\mathrm{Ca}^{2+}$ release [344-346]. Mitochondrial damage and $\mathrm{Ca}^{2+}$ imbalance are pathological features of $\mathrm{AD}$ [347-349]. It was suggested that increased expression of CypD could play an important role in the neurodegenerative process as in AD. It was shown that $\mathrm{A} \beta$ interacts with CypD [350,351], and induces mitochondrial and neuronal stress. Recent studies also demonstrated a link between mitochondrial dysfunction and tau pathology as a contributor to $\mathrm{AD}[352,353]$.

\subsection{Interactions of Tau with Proteins Regulating Programmed Cell Death}

The apoptosis, one of the consequences of the developed A $\beta$ and tau pathology [354], is an important physiological cell process mediated by various proteins including caspases, the cysteine aspartyl proteases [355]. Interactions of tau with caspases were confirmed by the study of Gamblin et al., where the authors suggest that caspases involved in $A \beta$-induced neuronal apoptosis could contribute to pathological cleavage of tau. They showed that tau is cleaved at Asp ${ }^{421}$ in vitro by caspases- $-1,-3,-6,-7$, and -8 , and the same 
cleavage product of tau is produced in primary rat cortical neurons after treatment with fibrillar $A \beta$ [112]. This cleavage of tau with caspases generates pathological truncated tau species which can aggregate, lead to neurofibrillary pathology, and contribute to neuronal death $[356,357]$. Although the caspase activation precedes the formation of neurofibrillary tangles, the soluble tau species are the caspase activators that augments tau truncation, thus contributing to NFT formation $[45,358]$.

Caspase- 1 is activated by proteolytic cleavage by other caspases, and it is a part of a pathway called pyroptosis: a lytic and inflammatory form of programmed cell death [359].

Caspase- 3 is involved in the activation cascade responsible for the execution of apoptosis. When caspase- 3 is activated, it cleaves its substrates caspase- $6,-7$, and -9 which simultaneously activates them. In the AD brain, caspase-cleaved tau colocalizes with both intracellular $A \beta$ and activated caspase-3 [113]. Through the cleavage of Ser/Thr Kinase 1 (Akt), caspase-3 regulates tau phosphorylation via the GSK3 $\beta$ kinase pathway [360]. Furthermore, upregulation of active caspase-3 led to the accumulation of caspase-3-cleaved tau in the traumatic brain injury model [361]. These data suggest that abnormal activation of caspase-3 may lead to progressive tau pathology.

Caspase-6 cleaves tau at three different sites in comparison to other caspases: Asp ${ }^{13}$ [362], Asp $^{402}$ [363] and Asp $^{421}$ [364]. Cleaved tau colocalized with active caspase-6 within NFTs in AD. Furthermore, active caspase- 6 was identified in the mild stage of AD which supports its role in the early stages of tau pathology $[365,366]$. Caspase- 6 (along with caspases-3 and -8) cleaves amyloid precursor protein (APP) at Asp ${ }^{664}$ releasing C-terminal p31 cytotoxic fragment which can induce apoptotic pathway cascade [367-370].

Caspase-7 is the effector caspase in programmed cell death which induces the Gasdermin-D-independent pore formation [371]. It cleaves tau at $\mathrm{Asp}^{421}$ [113]. In the study by Ayers et al., the individuals homozygous for AD-risk APOE4 allele and had loss-of-function mutation in the CASP7 gene did not develop the AD [372], this implicates the neurotoxic role of caspase-7. However, a genetic association study identified a different, rare missense variant of the $C A S P 7$ gene to be robustly associated with familial late-onset $\mathrm{AD}[373]$.

Caspase- 8 is the most upstream protease in the activation cascade of caspases [374]. It activates caspase- 3 by proteolytic cleavage [375]. Furthermore, it has been shown that in the brain of $\mathrm{AD}$ patients, the active form of caspase- 8 is abundantly present in NFT-bearing neurons [376]. In contrast, a gene association study that found two mutations in the CASP8 gene: K148R and I298V also showed in vitro that mutation I298V had an attenuating effect on caspase-8 activity [377]. Interestingly, de Calignon et al. noted that after the formation of NFT in neurons, the caspase activity is suppressed [45].

The next TIP involved in apoptosis is the neuronal pentraxin-1 (NPTX1) [77]. Under physiological conditions, the NPTX1 is released from synapses into the synaptic cleft, binds extracellularly to AMPA glutamate receptors (AMPARs), and stabilizes them on dendritic surfaces [378,379]. Thus, the secreted NPTX1 binds and recruits AMPARs, promoting the formation of an active synapse [380,381]. It has been shown that under potassium deprivation and reduced neuronal activity, NPTX1 protein is overexpressed along with other proteins involved in programmed cell death $[382,383]$. Furthermore, exposure to $A \beta$ also increased NPTX1 expression leading to reduced neurite outgrowth and increased apoptosis. Moreover, NPTX1 overexpression alone reproduces the effects of A $\beta$ on neurite damage and apoptosis [384].

\subsection{Proteolytic Cleavage and Truncation of Tau Protein}

Protein degradation is an important physiological process, which is responsible for the removal of aged, damaged, or misfolded proteins with the possibility of their constituents being recycled in the process [385]. Proteolytic cleavage of specific proteins is the common denominator of many neurodegenerative diseases including huntingtin protein in Huntington's disease [386,387], $\alpha$-synuclein in Parkinson's disease and Lewy body dementia [388], ataxins in cerebral ataxia [389,390], prion protein in prionosis [391,392] and tau 
protein in Alzheimer's disease, as mentioned in Section 1 [117]. Experiments deciphering PHF showed that the "minimal protease-resistant" core of paired helical filaments are mainly composed of tau proteins and that the majority of them are truncated [393-395]. A general consequence of proteolysis is the production of various fragments with a toxic gain-of-function that can be translocated into an inappropriate cell compartment $[358,396]$. Pathological tau protein fragments can either switch on the cell death cascade or induce and drive protein aggregation. Mounting evidence supports the idea that truncated protein fragments are upstream in the pathological cascade and can form the initial seeds for the aggregation in neurodegenerative diseases [45,397-399]. For example, the cleavage of tau monomers to truncated fragments supports its mounting into oligomers and PHF [117].

Two calcium-regulated thiol-proteases are known to interact with tau: calpain-1 [400] and calpain-2 [401], and they are major isoforms of calpains in the brain. Calpains can cleave tau in vitro [402]. Calpain-1 participates in long-term potentiation and acts neuroprotective on neurons. On the other hand, calpain-2 activation limits neuronal potentiation leads to silencing of neuronal activity, and neuronal death [403]. Calpain-1 showed an increase in activity in AD from Braak stage III to the late stages of the disease [404]. Activation of both calpains leads to the production of 10.7-kDa tau fragment in neurons (tau 125-230, related to 2N4R tau), which is neurotoxic [405,406]. Additionally, calpain-1 cleaves tau at $\mathrm{Arg}^{242,}$ and this fragment is observed in brains with tauopathy [407]. Furthermore, a recent study by Cicognola et al. showed that in tauopathy, calpain-2 cleaves tau at Lys ${ }^{224}$ [408], a fragment enriched in CSF tau pool in pathological conditions [409].

In addition to thiol-proteases, legumain [410,411] and ubiquitin thioesterase OTUB1 [412] are also known as TIPs. The legumain is predominantly localized in lysosomes and it is a multifunctional enzyme that can have endopeptidase, carboxypeptidase, or ligase activity depending on their milieu [413]. Increased levels of the active legumain along with a higher amount of proteolytically truncated tau were found in the cytoplasm of neurons in AD $[410,414]$. Ubiquitin thioesterase OTUB1 belongs to the deubiquitination family proteins. It is involved in the processing of poly-ubiquitin precursors, as well as ubiquitinated proteins [415]. OTUB1 was shown to be involved in the deubiquitination of tau protein thus preventing its degradation [416]. Furthermore, expression of OTUB1 in primary neurons increased tau levels, enhanced tau aggregation, and contributed to tau pathology [412].

Cathepsin D (CTSD) is the lysosomal aspartic acid protease involved in cleavage and activation of ADAM30 which leads to amyloid precursor protein (APP) degradation and thus preventing the formation of $A \beta$ peptides and plaque load [417]. The study of Khurana et al., examined the relationship between CTSD and tau in vivo using the Drosophila model of $\mathrm{AD}$ and showed that CTSD is upregulated with age and has a neuroprotective effect. The deletion of the Ctsd gene in this model increased the generation of $\mathrm{Asp}^{421}$-cleaved tau protein and exacerbated tau toxicity. Additionally, the authors showed that ablation or silencing of the Ctsd gene also in mice and sheep resulted in the truncation of tau at $\mathrm{Asp}^{421}$ and caspase-3 activation [418]. CTSD has many cellular functions including activation of enzymes, such as ADAM30, and various enzymatic precursors [419], degradation of intracellular proteins [420,421], activation and degradation of hormones and growth factors [422,423], processing of enzyme activators and inhibitors [424], processing of brain-resident proteins, such as tau [425], myelin [426] or A $\beta$ [427], and regulation of apoptosis [428]. It was shown that genetic variation in the CTSD gene is a risk factor for AD [429].

Human high-temperature requirement serine protease A1 (HTRA1) and thrombin are two serine proteases known to cleave tau protein [400]. HTRA1 is able to degrade tau aggregates and fibrils, and patients with elevated expression of HTRA1 had lower amounts of accumulated tau protein in the brain [400,430]. Thrombin, an extracellular protease, cleaves tau protein at various arginine and lysine residues. Its proteolytic activity is inhibited by the phosphorylation of its substrates. PHFs isolated from the AD brain were more resistant to thrombin cleavage than those that were dephosphorylated [431]. 
The $26 \mathrm{~S}$ proteasome complex, which comprises 19S regulatory particle (19S RP) and $20 \mathrm{~S}$ core particle (20S CP) [432], interacts directly with tau protein [433]. Furthermore, two of nine subunits of the base complex of 19S RP are TIPs: the 26S proteasome regulating subunit 7 (PSMC2) [293] and 26S proteasome non-ATPase regulatory subunit 2 (PSMD2) [77]. The main role of 19S RP is the degradation of ubiquitinated proteins in an ATP-dependent manner [434-436]. The PSMC2 subunit is a motor protein with ATPase activity. The PSMD2 recognizes and binds ubiquitin bound Usp14, a ubiquitin-specific protease, which cleaves polyubiquitin chains from substrates before entering the $26 \mathrm{~S}$ proteasome core [437,438]. However, in tauopathies, the ubiquitin-dependent proteasomal system is impaired [75] and tau protein aggregates may inhibit proteasome function [439,440]. Furthermore, pathological protein aggregates may have a suppressive effect on the proteasome system, as demonstrated by Thibaudeau et al. who showed that $A \beta$ oligomers can bind to the 20S CP [432] and thus impair substrate entry into the 26S proteasome [441].

Only one metalloprotease that can degrade tau has been reported so far, the puromycinsensitive aminopeptidase (PSA) [442]. It was shown that PSA more efficiently degraded soluble tau from the normal human brain when compared to soluble or PHF tau purified from AD brain, very likely due to post-translational modifications and/or aggregation of tau. PSA is upregulated in patients with tauopathies [443], but its role in tau pathology is not known yet.

Presenilin-1 (PSEN1) is a part of the $\gamma$-secretase complex, which cleaves integral membrane proteins such as Notch receptors and APP [444,445]. Mutations in this gene are risk factors for developing familial Alzheimer's disease [446,447]. It has been shown that PSEN1 facilitates the phosphorylation of tau protein through direct interaction with tau and glycogen synthase kinase $3 \beta$ (GSK3 $\beta$ ) and thus guiding the GSK3 $\beta$ into close proximity with tau for phosphorylation [448]. Moreover, two AD-characteristic mutations in PSEN1 increased its binding to GSK3 $\beta$ and enhanced the phosphorylation of tau protein [449]. However, the exact mechanism as to how PSEN1 contributes to tau pathology remains unanswered.

\subsection{Proteins Involved in the Regulation of the Cytoskeleton and Intracellular Transport}

Cytoskeleton regulating proteins are essential for maintaining and regulating the shape and function of the cytoskeleton, axons, dendrites, and synapses [450]. Furthermore, they are important for axonal growth, cellular transport, and axonal signal transmission $[451,452]$. The cytoskeleton proteins show abnormalities during tauopathies, like the inhibition of assembly or deformation of microtubules and invaginations of the nuclear membrane [453,454]. Cytoskeleton constituents, such as tubulins (4 isoforms) [292,455-457] and actin ( 3 isoforms) [80], which polymerize into filaments and microtubules (MTs) are stabilized and co-organized by microtubule-associated proteins (MAPs) or actin-binding proteins (ABPs) [81].

Another cytoskeleton-regulating TIP is the microtubule-associated protein 2 (MAP2) [458], which belongs to the category of microtubule-binding proteins. Strong MAP2 immunoreactivity was observed mainly in dendrites of neurons and occasionally in neuronal soma. MAP2 regulates the spacing between MTs in dendrites and is involved in dendrite arborization and growth [459]. The induction of long-term potentiation in cultured primary rat neurons and mice hippocampal slices caused translocation of MAP2 from dendritic shafts to dendritic spines and heads. This suggests that MAP2 is involved in processes of synaptic plasticity and learning [460]. The other function of MAP2 is the regulation of axonal transport. It was observed that in sensory neurons MAP2 coordinates the functions of molecular motors kinesin- 1 and kinesin-3, where it inhibits slow kinesin- 1 and thus allowing fast kinesin- 3 to drive cargo transport from the soma into the axon [461]. The importance of physiological interaction of tau with MAP2 has not been revealed yet, however, it was shown that hyperphosphorylated tau protein isolated from AD brain inhibits MAP2-promoted MT assembly [458].

The microtubule dynamics rely on the assembly or disintegration of tubulins on plusends of microtubules [462]. These dynamics are regulated by the presence or absence of 
factors and proteins such as the GTP-bound tubulin dimers [463], tau protein [464,465], or plus-end tracking proteins [466]. The two plus-end tracking proteins are known to directly interact with tau, the microtubule-associated protein RP/EB family member 1 (MAPRE1) [467] and 3 (MAPRE3) [467]. They promote and regulate MT nucleation and elongation [468,469]. Moreover, the MAPRE1 and MAPRE3 also regulate the minus-end of MTs and mediate the tethering of MTs to the Golgi apparatus [469]. Tau protein, through interaction with MAPRE1 and MAPRE3, inhibits their binding to MTs and this inhibition is abolished by tau phosphorylation at $\operatorname{Ser}^{262}$ [470]. Furthermore, MAPRE1 and MAPRE3 could be directly involved in tau secretion from the cells [471]. These data suggest the existence of a tight relationship between tau and end-binding proteins.

The next TIP from the class of cytoskeleton-regulating proteins is amphiphysin II $[327,472,473]$, which controls the plasma membrane curvature, shaping, and remodeling [474]. Amphiphysin II is abundantly expressed in the brain and muscle cells [475]. Using genome-wide association studies, the variations in its gene (BIN1) were identified as the second most risky genetic factor for sporadic Alzheimer's disease [476]. It was shown that under pathological conditions amphiphysin II expression is elevated [473,477]. However, the direct function of amphiphysin II in tau pathology remains unknown.

Protein kinase $C$ and casein kinase substrate in neurons 1 (PACSIN1) is a flexible adaptor protein that contains important SH3 and F-BAR domains which are known to interact with many proteins. The F-BAR domain regulates membrane deformation and shaping of the neuronal plasma membrane $[478,479]$. PACSIN1 interacts with the proline-rich region (PRR) of tau through its SH3 domain, and by this interaction, it coordinates the remodeling of the MT cytoskeleton [79]. Moreover, PACSIN1 plays a role in the reorganization of the actin cytoskeleton thus facilitating the membrane fission during endocytosis [480]. It plays a role in neurodevelopment and during this process, it is upregulated [481]. The PACSIN1 is the key regulator of endocytic removal of developmental NMDARs and their replacement with mature NMDARs [482], which comprise different subunits, and thus possess other synaptic attachment and kinetic properties [483-485]. Through this replacement of developmental/mature NMDARs, PACSIN1 regulates the formation of new synaptic connections and is important for learning and memory creation.

One of the novel TIPs that we have recently identified is the brain-specific angiogenesis inhibitor 1-associated protein 2 (BAIAP2) [77]. It is the adapter protein that links membrane-bound small G-proteins to cytoplasmic effector proteins. The BAIAP2 binds and deforms the membranes by its I-BAR domain and may be involved in the formation of membrane curvatures, which are present for example in synapses or dendrites [76,78]. I-BAR domain is also capable of binding and bundling the actin filaments [486]. The SH3 domain of BAIAP2 binds various effectors, whereby many of them are actin modulatory proteins that participate in the nucleation of branched actin filament networks $[487,488]$. Furthermore, the BAIAP2 participates in the outgrowth of neuronal processes [489] and may be involved in insulin-mediated neurite development and synaptic plasticity [490,491]. BAIAP2 in CNS is located mainly in axonal synapses and dendritic spines and regulates their morphology, as was revealed by electron microscopy [492]. Moreover, their association with psychiatric disorders has been revealed, such as schizophrenia [493,494], autism spectrum disorders [495,496], and attention deficit hyperactivity disorder [497].

The intracellular transport, which is tightly dependent on the cytoskeleton, is commonly impaired in AD. One of the tau-associated proteins implicated in intracellular transport is the hook microtubule-tethering protein 3 (HOOK3), which is expressed predominantly in neurons. HOOK3 belongs to a family of cytoplasmic linkers that participate in endosomal transport. The HOOK3 was shown to associate mainly with tau aggregates, and weak interaction with monomeric soluble tau was also reported [498].

The regulators of nucleocytoplasmic transport are also represented among the TIPs by the GTP-binding nuclear protein RAN [77] and by the nuclear pore complex protein NUP98. The RAN belongs to the Ras superfamily [499], and its GTP-bound form (RANGTP) is required for mitotic spindle assembly, and thus for cell proliferation [500,501]. 
Both RAN and NUP98 mediate the transport of proteins and RNA between the nucleus and cytosol through the nuclear pore complex (NPC) [502-504]. A study focusing on nucleocytoplasmic transport in $\mathrm{AD}$ showed that hyperphosphorylated tau interacts directly with the FG domain of NUP98 and causes the disruption of nucleocytoplasmic transport. Upon interaction with hyperphosphorylated tau, NUP98 becomes mislocalized to the cytoplasm and promotes tau aggregation into NFT. As NUP98 also interacts with RAN and regulates the RAN-GTP/GDP exchange through NPC, mislocalization of NUP98 results in disruption of nucleocytoplasmic equilibrium of RAN, its depletion in the nucleus and nucleocytoplasmic transport failure [94]. The impact of pathological forms of tau protein on RAN function is currently unknown.

Next TIP, the apolipoprotein E (APOE) [505] associates with lipid particles and plays a role in lipoprotein-mediated lipid transport [506-508]. APOE has three common isoforms: APOE2, APOE3, and APOE4 [509], with different levels of lipidation and related functions. Individuals possessing the APOE4 allele have significantly smaller APOE-containing particles compared to individuals without an APOE4 allele [510]. Carrying the APOE4 allele is considered a genetic risk factor for $\mathrm{AD}$, with the increase of risk by three-fold for one allele, and lower age of onset for AD [511]. APOE in the healthy brain plays a neuroprotective role, by binding tau and blocking the phosphorylation sites for kinases [512]. However, only APOE3 and APOE2 can bind tau, not APOE4 [505]. A study proposed genetic interaction between APOE and tau in the development of AD, in a way where the polymorphic tau $G$ allele represents an additional risk factor in the individuals carrying the APOE4 allele, with a five-fold increased risk of $A D$ development [513]. In clinical AD, A $\beta$ mediates the association of APOE with PHF, which correlates with cognitive decline [514].

The motor protein kinesin- 1 was also identified as a tau-interacting protein. More precisely, its two light chains, the kinesin light chain 1 (KLC1) and 2 (KLC2) were identified as TIPs [60,515]. KLC1 and KLC2 are present in the complex with the kinesin-1 heavy chain and are responsible for the binding of cargo membrane vesicles, which kinesin-1 motor complex transports along the axon from the neuronal soma to synapses. By interacting with tau protein, both KLC1 and KLC2 participate in the axonal transport of tau in healthy neurons [60]. Whereas the KLC1 is enriched in neurons, the KLC2 is ubiquitously expressed across the various tissues [516]. In the healthy brain, the KLC1 also participates in the transport of amyloid precursor protein (APP) through its attachment to the KLC ligand calsyntenin-1 [517,518], a transmembrane protein present in membranes of APP-containing vesicles in the Golgi [519]. The phosphorylation of KLC1 on Ser ${ }^{460}$ reduces the interaction of KLC1 and calsyntenin-1 thus leading to reduced axonal transport [520]. In the AD brain, the levels of the KLC1 are reduced and the phosphorylation of the Ser ${ }^{460}$ is increased which results in the inhibition of axonal transport of APP [521]. Similarly, the levels of the KLC2 are also decreased in the frontal cortex of AD patients [522]. In the animal model expressing pathological tau proteins, a simultaneous reduction of kinesin light chain expression slowed axonal transport and increased the accumulation of hyperphosphorylated tau and tau aggregates [523].

Another TIP is the dynactin subunit 1 (DCTN1) [61]. This protein is part of the dynactin complex which is responsible for recruiting and tethering the dynein motor complex to MTs [524,525]. Interaction of tau with DCTN1 enhances the binding of the dynactin complex to MTs [61]. Direct involvement of DCTN1 in tau pathology has not been revealed yet.

The mitochondrial import receptor subunit TOM20 homolog (TOMM20) is the part of the translocase of the outer mitochondrial membrane (TOM), a protein complex responsible for the recognition and translocation of cytosolically synthetized proteins into the intermembrane space of the mitochondria [526]. The evidence of TOMM20 as TIPs arises from the study by Amadoro et al. which showed that TOMM20 binds caspase-truncated tau [343]. In AD, the reduced immunoreactivity of TOMM20 was observed. The decreased levels of TOMM20 can lead to an impairment of the recognition and binding of proteins intended for translocation into mitochondria $[527,528]$. This could contribute to the damage 
of oxidative phosphorylation as seen in AD. Additionally, the TOM complex can bind and translocate $A \beta$ peptides which results in the accumulation of $A \beta$ in mitochondrial cristae [529].

The ADP / ATP translocase 1 (ANT1) is an ADP-ATP antiporter located at the mitochondrial inner membrane and mediates the import of ADP into the mitochondrial matrix for ATP synthesis in exchange for the export of ATP [530]. Its ANT1 gene is involved in the maintenance and replication of mitochondrial DNA [531], and its mutations are associated with different mitochondrial disorders affecting the brain [532]. Similarly, as in the case of TOMM20, the caspase-truncated tau fragment can bind ANT1, which either alone or in association with other synaptotoxins can induce synapse decay [343]. The interaction of truncated tau with ANT1 also inhibits its ADP/ATP exchange activity which is one of the factors triggering mitochondrial dysfunction.

The excitatory amino acid transporter 2 (EAAT2) was also identified as TIP and was shown to preferentially interact with tau phosphorylated at AD-characteristic phosphosites. Furthermore, EAAT2 is recruited into NFT which suggests some role for EAAT2 in tau pathology [533].

Alpha-synuclein ( $\alpha$-syn) [534] is mainly distributed in the presynaptic terminals of neurons [535]. In the healthy brain, $\alpha$-syn has many different functions like modulation of vesicle trafficking [536], the suppression of apoptosis [537], modulation of synaptic plasticity [538], or chaperone activity [539]. In pathological conditions, $\alpha$-syn aggregates and forms Lewy bodies, which are typical hallmarks of Parkinson's disease and other synucleinopathies. In around $50 \%$ of AD cases, $\alpha$-syn pathology is also reported [540,541]. It was shown that the $\alpha$-syn monomers assemble into amyloid-like fibrils which are able to interact with tau, resulting in inhibition of microtubule assembly and their stabilization. The tau subsequently aggregates which could promote the pathological pathway in synergy [542,543]. $\alpha$-syn also increases the GSK3-mediated phosphorylation of tau that can further enhance the progress of disease [544]. Furthermore, it was proposed that pathological $\alpha$-syn is able for cell-to-cell transmission, similar to prion diseases [543].

\subsection{Tau-Interacting Proteins Involved in DNA Replication and Transcription}

Neurons are post-mitotic cells, which are unable to further divide, and are in the resting phase of the cell cycle [545]. In tauopathies, like AD, several changes influence the processes of replication and transcription. It was found that translocation of tau to the nucleus, where it binds and protects DNA under physiological conditions, is reduced upon its hyperphosphorylation; thereby, heterochromatin organization is disrupted leading to cell cycle re-entry and neuronal death [546]. Furthermore, dysregulated gene expression and rRNA synthesis occur resulting in the rise of altered protein synthesis [547,548]. From the group of DNA replication and transcription proteins only two are currently verified as TIPs: the apoptosis-antagonizing transcription factor (AATF) [549] and mothers against decapentaplegic homolog 2 (SMAD2) [550].

AATF is a transcriptional regulator involved in cell proliferation. AATF binds the retinoblastoma protein $(\mathrm{Rb})$ and inhibits its function. The role of $\mathrm{Rb}$ is growth suppression via expressional regulation of genes required for DNA synthesis and cell progression [551]. AATF is also an inhibitor of $A \beta$ production in cells undergoing apoptosis by binding and blocking the pro-apoptotic WT1 regulator (PAWR) activity in the regulation of APP processing [115]. On the other hand, AATF participates in neurodegeneration due to its capability to stimulate DNA synthesis and induce quiescent cells to re-enter the cell cycle. AATF-tau association is also shown to be modulated during the onset of neuronal apoptosis in the cytoplasm of cerebral granule neurons, and this interaction is progressively lost in apoptosis [549]. However, the consequences of AATF interaction with tau have not been examined so far. 
SMAD2 acts in a complex of SMAD2/SMAD2/SMAD4 or SMAD2/SMAD3/SMAD4 as a transcriptional co-activator on SMAD-binding elements of DNA. SMAD2 is a part of the TGF $\beta$ signaling pathway, and along with other SMAD proteins, it is the most important effector of this cascade. TGF $\beta$ activates the phosphorylation of SMAD2 and SMAD3 and starts the assembly and translocation of the SMAD2/SMAD3 complex into the nucleus [552]. In AD, SMAD2 is also a part of the TGF $\beta$ /SMAD2/STAT3 signaling pathway which is activated by APOE, the important risk factor for $\mathrm{AD}$, and increases the amyloidogenic processing of APP leading to A $\beta$ formation and contributes to cognitive decline [553]. Inversely, SMAD2 plays a role in CX3CL1/TGF $\beta$ /SMAD2 pathways which control adult neurogenesis [554]. Thus, SMAD2 signaling pathways can contribute either to neurodegeneration or neuroprotection. Furthermore, it was shown that the interaction of hyperphosphorylated tau with phosphorylated SMAD2 resulted in reduced translocation of SMAD2 into the nucleus [555].

\subsection{Tau-Interacting Proteins Involved in RNA Processing and Translation}

The group of RNA processing and translational proteins is a part of the large protein family, called RNA-binding proteins (RBPs), which are active in the processes like mRNA maturation including splicing, targeting, degradation, and translation of the RNA [556,557]. In $\mathrm{AD}$, several changes to RBPs, and thus to the processing and translational machinery occur. The activity of the spliceosome in AD is impaired resulting in a lower splicing efficiency and production of mRNAs with introns. Splicing deficiency in AD leads to an altered expression of protein-encoding genes like APP which can be detrimental [558]. Furthermore, impaired alternative splicing leads to a dendritic loss in primary neurons and weakened memory in mice [559]. Two proteins from the group of RBPs were validated as TIPs: the U1 $70 \mathrm{kDa}$ small nuclear ribonucleoprotein (SNRNP70) [560] and the T-cellrestricted intracellular antigen-1 (TIA1) [561].

The SNRNP70 is a component of the U1 small nuclear ribonucleoprotein (snRNP) complex which is responsible for the recognition of the pre-mRNA 5' splice-site and the subsequent assembly of the spliceosome [562]. In AD, SNRNP70 is internally cleaved, and its $40 \mathrm{kDa}$ fragment participates in the formation of protein aggregates and was found in close proximity with NFTs [558]. Moreover, this fragment exerts toxic effects on neurons [563]. The truncated, aggregated forms of SNRNP70 are able to bind and sequester the soluble SNRNP70 into insoluble aggregates [564]. The SNRNP70 aggregation occurs earlier in $\mathrm{AD}$ and its levels correlate more with $\mathrm{A} \beta$ plaques compared to pathological tau aggregates. It was shown that in AD, the LC1/BAD domain of SNRNP70 interacts with tau, a process that does not occur under physiological conditions [560], and it causes mislocalization of SNRNP70 from the nucleus to the cytoplasmic phospho-tau aggregates. These pathological changes of SNRNP70 affect the whole U1 snRNP complex, leading to the loss of the spliceosome function and thus impaired splicing of pre-mRNAs [558,565].

TIA1 is a protein with several different functions in neurons. It plays a role in the regulation of RNA localization and utilization, splicing [566], dendritic arborization [561], and it is also one of the primary stress granule proteins active in stress response [567]. In the healthy brain, tau participates in translational stress response by the promotion of stress granule (SG) formation, which allows adaptation of the protein synthesis and thus copes with stress. Under neuropathological conditions, TIA1 aggregates with pathological tau proteins and creates abnormal SGs; however, the clear consequences of these abnormal SGs are unknown [561]. Tau and TIA1 have a reciprocal effect on themselves. Tau can facilitate the assembly of TIA1 stress granules, and TIA1 facilitates the aggregation of phosphorylated and altered tau [568], and the binding of TIA1 to tau oligomers promotes their stabilization and accumulation. Furthermore, reduction of TIA1 levels prevents tau oligomers propagation and toxicity. TIA1 regulates the toxicity of tau oligomers by the determination of their amount and thus the response of neurons to toxic tau oligomers by binding them into stress granules [569]. However, TIA1 can also stabilize prefibrillar tau aggregates and inhibit their further assembly into large fibrils [570]. 


\subsection{Signal Transduction Mediators Interacting with Tau}

Signaling pathways in the cells regulate many different, important, and basic processes, like cell growth, proliferation [571], metabolism, cell-to-cell communication, regeneration [572], apoptosis, and stress response. Signaling pathways comprise four categories of components: surface or intracellular receptors, enzymes, transcription factors, and signal mediators [573,574]. In tauopathies, changes in signaling pathways occur, such as the cell cycle pathway, response to stress, and $\mathrm{Ca}^{2+}$ signaling pathway. For example, oxidative stress in neurons can provoke stress responses and induce several signaling pathways, like the stress-activated protein kinase pathways (JNK-SAPK and p38-SAPK2). These pathways result in either stress adaptation or apoptosis, thus their outcomes can be neuroprotective or neurodegenerative [575]. Changes in the $\mathrm{Ca}^{2+}$ signaling pathways occur in $\mathrm{AD}$, where they lead to progressive decline in memory and apoptosis [576]. Currently, eleven proteins that are components of signaling pathways were experimentally confirmed as TIPs.

The 14-3-3 adaptor proteins regulate a wide range of pathological and physiological processes [577]. They are involved in neuronal migration, neuromorphogenesis, synaptogenesis, and development of the nervous system, including neurogenesis and differentiation [578]. They also participate in neurodevelopmental disorders by the regulation of the subcellular localization and activity of target proteins [579]. In pathological conditions, they can participate in the development of neurodegeneration or can be neuroprotective. For example, 14-3-3 zeta facilitates GSK3 $\beta$-dependent tau phosphorylation by the affinity enhancement of GSK3 $\beta$ for tau [580]. 14-3-3 zeta-bound proteins are also resistant against protein phosphatases, which enhance the strength and duration of kinase-dependent signals under pathological conditions. The 14-3-3 proteins bound to tau favor tau phosphorylation and aggregation [581]. They were found also in NFT [582]. However, they also play a neuroprotective role by inhibiting the cell cycle activation and preventing neuronal death [583]. A more comprehensive description of the interaction of 14-3-3 proteins with tau was recently reviewed by Chen et al. [584].

The next TIP involved in signaling is the growth factor receptor-bound protein 2 (GRB2) [235], an adapter protein that plays a key role in Ras-mediated growth factor signaling, proliferation, and cell cycle. GRB2 also presents an important link between cellular signaling and neuronal cytoskeleton [235]. In a healthy brain, GRB2 is localized in the neuronal body and its projections, while in the $\mathrm{AD}$, it disappears from projections and is restricted only to neuronal soma [585]. GRB2 interacts with tyrosine-phosphorylated APP in AD [586]. GRB2 is involved in the activation of the mitogen-activated protein kinase (MAPK) pathway leading to abnormal tau phosphorylation [587]. However, the direct consequence of tau interaction with GRB2 is unknown.

The prosaposin receptor Gpr37-like 1 (GPR37L1) [77] is the G-protein coupled receptor exclusively expressed in the nervous system and is abundant in the human brain [588]. It possesses functional similarity to the prosaposin receptor GPR37 (GPR37), which is a substrate for E3 ubiquitin-protein ligase parkin. Both receptors, GPR37 and GPR37L1 bind the neurotrophic protein prosaposin and its active fragment prosaptide, which causes the endocytosis of both receptors upon binding and activation of the ERK phosphorylation pathway. Prosaposin as the neurotrophic factor promotes cell survival, neurite outgrowth, and differentiation [589]. One study revealed that GPR37L1 is a constitutively active receptor-independent from prosaposin binding and that its activity is down-regulated by ADAM metalloprotease [590]. The GPR37L1 was only recently identified as TIP [77], however, the consequence of its interaction with tau protein has not been elucidated.

Hepatocyte growth factor-regulated tyrosine kinase substrate (HGS) [591] is involved in intracellular signal transduction mediated by cytokines and growth factors and is a part of the ESCRT-0 sorting complex. HGS is essential for the binding of ubiquitylated cargo into multi-vesicular bodies (MVBs), which are important for the lysosomal recycling of plasma membrane proteins [592]. Furthermore, HGS is also an effector of the small GTPase Rab35, which catalyzes the ESCRT-0 complex recruitment and MVBs formation [593]. The Rab35 and the ESCRT-0 machinery are active in the regulation of total tau turnover and 
specific phospho-tau species by lysosomal degradation since tau proteins are present in HGS-positive early endosomes [591]. In AD, impairment of tau proteostasis occurs, which is linked to neuronal and synaptic dysfunction. In the early stages of $A D$, abnormalities of the endolysosomal pathway, like high levels of lysosomal hydrolases and endosomal enlargement [594], and dysregulation of the hypothalamic-pituitary-adrenal axis occur, which lead to elevated glucocorticoid levels [595]. Moreover, the high glucocorticoid levels impair tau degradation by the downregulation of Rab35 expression, which suppresses the sorting of tau into the ESCRT pathway and the formation of the HGS-positive endosomes containing tau. In addition, HGS levels are significantly decreased in AD, which suggests that molecular components critical for membrane protein sorting in the endocytic pathway are altered [596]. This results in the accumulation of ubiquitinated tau and related neuronal death [591].

JNK-interacting protein 1 (JIP1) mediates the JNK signaling and MAPK kinase cascade activation. JIP1 binds to the kinesin-I motor complex and regulates the release of cargo from the kinesin at the transport destination. Phosphorylated tau interacts with JIP1 and re-localizes it from axons to neuronal soma. This interaction was shown to be pathological because it competes with the binding of JIP1 to kinesin leading to failure of JIP1-mediated phosphorylation of the kinesin motor complex and damage of the anterograde axonal transport [597].

LIM and senescent cell antigen-like-containing domain protein 1 (LIMS1) are required for the formation of multi-protein complexes and facilitate cell proliferation, migration, and survival [598]. During neuronal development, LIMS1 is necessary for the maintenance of neuronal polarity and communication in synapses [599]. In a healthy brain, the levels of LIMS1 are nearly undetectable, while during neurodegeneration it is robustly expressed [600]. In the study by Ozdemir et al., authors propose that LIMS1 plays a role in tau hyperphosphorylation and the stabilization of abnormally hyperphosphorylated tau [598].

The phospholipase C-gamma-1 (PLCG1) is essential for the production of diacylglycerol and inositol 1,4,5-triphosphate, the second messenger signaling molecules [601]. PLCG1 participates in the pathways of growth factor neutrophins in neurons and is involved in the development of the brain, cytoskeleton organization, and synaptic plasticity [602]. PLCG1, along with protein kinase D1, participate in the neuroprotective function of APOE-containing lipoproteins, through anti-apoptotic signaling [603]. In AD, PLCG1 levels are lower than in a healthy brain [604]. Tau protein interacts directly with the SH3 domain of PLCG1 by the PXXP motif in the proline-rich region and this interaction is regulated by phosphorylation of tau [235]. This suggests that tau may be involved in the regulation of signal transduction mediated by PLCG1.

\section{Current Therapeutic Approaches Targeting Tau and Its Interacting Partners}

The modulation of the interaction between Tau and its partners has been applied for the development of therapeutics for AD and PSP. The modulators in clinical trials can be divided into four groups, such as inhibitors of phosphorylation, acetylation, and de-glycosylation and molecule-activated dephosphorylation. The drugs in clinical studies and their outcome are summarized in Table 5. 
Table 5. Compounds in clinical trials targeting tau interactions with its PPIs.

\begin{tabular}{|c|c|c|c|c|}
\hline Name & Function & Phase (Disease) & Efficacy & Source \\
\hline Dasatinib & Ab1 and Src kinase inhibitor & Phase I and II & Recruiting & NCT04063124 \\
\hline Epigallocatechin gallate & DYRK1A kinase inhibitor & Phase II (AD) & No results posted & NCT00951834 \\
\hline Lithium chloride & GSK-3 kinase inhibitor & Phase II (AD/PSP) & No effect & $\begin{array}{l}\text { NCT00088387 } \\
{[605]}\end{array}$ \\
\hline Nilotinib & Ab1 kinase inhibitor & Phase II (AD/PD) & Unknown & $\begin{array}{l}\text { NCT02947893 } \\
{[606]}\end{array}$ \\
\hline Saracatinib & Ab1, Src kinase inhibitor & Phase II (AD) & No effect & $\begin{array}{l}\text { NCT02167256 } \\
{[607,608]}\end{array}$ \\
\hline Tideglusib & GSK-3 kinase inhibitor & Phase II (AD/PSP) & No effect & $\begin{array}{l}\text { NCT01350362 } \\
{[609-612]}\end{array}$ \\
\hline Valproate & GSK-3 kinase inhibitor & Phase III (AD) & No effect & $\begin{array}{l}\text { NCT00071721 } \\
{[613-615]}\end{array}$ \\
\hline Memantine & PPP2CA activator & Phase IV (AD) & No effect & $\begin{array}{l}\text { NCT00469456 } \\
{[616]}\end{array}$ \\
\hline Sodium selenate & PPP2CA activator & Phase II (AD) & Small positive effects & [617] \\
\hline Salsalate & Acetylation inhibitor & Phase I (AD/PSP) & Ongoing & $\begin{array}{l}\text { NCT03277573 } \\
{[618]}\end{array}$ \\
\hline Minocycline & $\begin{array}{l}\text { CDK5 kinase/caspase-3 } \\
\text { inhibitor }\end{array}$ & Phase II (AD) & No effect & NCT01463384 \\
\hline Nicotinamide & HDAC inhibitor & Phase II & Recruiting & NCT03061474 \\
\hline Phenylbutyrate & HDAC inhibitor & Phase II & Ongoing & NCT03533257 \\
\hline Vorinostat & HDAC inhibitor & Phase I & Recruiting & NCT03056495 \\
\hline
\end{tabular}

Several more drugs which have TIPs as targets are currently in the preclinical phases of development. Most of them have the same targets as modulators in clinical trials. Among them are inhibitors targeting Cdk5 kinase [619], two inhibitors of caspases [620-622], several HDAC6 specific inhibitors [623-626], and modulators of chaperones Hsp90 [627] and Hsp70 [628,629]. All of them showed modulation of tau protein modifications (phosphorylation, acetylation, etc.) and thus influencing their interaction with tau protein.

\section{Conclusions}

The exact causes of tau pathology in Alzheimer's disease (AD) and other tauopathies have not been well understood and are under the broad current research. Besides tau pathology, the next widely accepted model of $\mathrm{AD}$ progression is the $\mathrm{A} \beta$ hypothesis, which is considered to be upstream of tau pathology by many researchers [630,631]. However, other insights on the initiation of tau pathology have been proposed, such as the impaired cholesterol metabolism [632], deregulated endocytosis [473,633], or overactivated microglia [634]. On the other hand, the pathological accumulation of tau proteins well correlates with the cognitive decline in individuals suffering from AD [635]. Furthermore, the recently developed positron emission tomography (PET) tracers raised against $A \beta$ and tau, showed that both types of pathologies initially start in different brain regions $[636,637]$. Moreover, it is suggested that the accumulation of the A $\beta$ occurs 20-30 years before the clinical onset of AD [638]. These seemingly contradictory facts demonstrate the need for a better understanding of the precise molecular mechanisms of upstream pathological processes in AD and other tauopathies.

Since protein-protein interactions (PPIs) represent a core part of each molecular pathway and biological process [639], it is important to study the interactome of proteins involved in diseases such as AD. Key players of affected molecular pathways could be suitable targets for drug development and disease-modifying therapies. The patholog- 
ical modifications of tau protein which include abnormal phosphorylation, truncation, acetylation, glycosylation, or ubiquitination are performed by various classes of enzymes interacting with tau. Therefore, it is proposed that interaction partners of tau protein and their corresponding molecular pathways may be responsible for the development of pathological forms of tau [640]. In this review, we summarized the current knowledge about the role of tau protein in physiology and pathology and reviewed the TIPs. We discussed the functions of individual TIPs in neurodegeneration and pointed out the several discrepancies and gaps in knowledge of their roles in tau pathology. We believe that this review will encourage basic research on TIPs and/or the targets for the development of effective therapies against tauopathies.

Author Contributions: Conceptualization, J.H.; writing-original draft preparation, J.S., K.P. and J.H.; writing-review and editing, J.S., K.P. and J.H.; supervision, J.H. All authors have read and agreed to the published version of the manuscript.

Funding: This work was supported by the Slovak Research and Development Agency (grant nos. APVV-16-0531 and APVV-18-0302), the Scientific Grant Agency of the Ministry of Education of the Slovak Republic (grant nos. VEGA 2/0123/21 and VEGA 2/0150/19), and the SAS Grants for PhD Students (grant no. APP0040).

Data Availability Statement: Not applicable.

Conflicts of Interest: The authors declare no conflict of interest.

\section{References}

1. Uversky, V.N. Intrinsic disorder, protein-protein interactions, and disease. Adv. Protein Chem. Struct. Biol. 2018, 110, 85-121.

2. Weingarten, M.D.; Lockwood, A.H.; Hwo, S.-Y.; Kirschner, M.W. A protein factor essential for microtubule assembly. Proc. Natl. Acad. Sci. USA 1975, 72, 1858-1862. [CrossRef]

3. Cleveland, D.W.; Hwo, S.-Y.; Kirschner, M.W. Physical and chemical properties of purified tau factor and the role of tau in microtubule assembly. J. Mol. Biol. 1977, 116, 227-247. [CrossRef]

4. Ferreira, A.; Busciglio, J.; Cáceres, A. Microtubule formation and neurite growth in cerebellar macroneurons which develop in vitro: Evidence for the involvement of the microtubule-associated proteins, MAP-1a, HMW-MAP2 and Tau. Dev. Brain Res. 1989, 49, 215-228. [CrossRef]

5. Takei, Y.; Teng, J.; Harada, A.; Hirokawa, N. Defects in axonal elongation and neuronal migration in mice with disrupted tau and map1b genes. J. Cell Biol. 2000, 150, 989-1000. [CrossRef] [PubMed]

6. Sotiropoulos, I.; Galas, M.C.; Silva, J.M.; Skoulakis, E.; Wegmann, S.; Maina, M.B.; Blum, D.; Sayas, C.L.; Mandelkow, E.M.; Mandelkow, E.; et al. Atypical, non-standard functions of the microtubule associated Tau protein. Acta Neuropathol. Commun. 2017, 5, 91. [CrossRef] [PubMed]

7. Wang, Y.; Mandelkow, E. Tau in physiology and pathology. Nat. Rev. Neurosci. 2016, 17, 5-21. [CrossRef]

8. Binder, L.I.; Frankfurter, A.; Rebhun, L.I. The distribution of tau in the mammalian central nervous system. J. Cell Biol. 1985, 101, 1371-1378. [CrossRef]

9. LoPresti, P.; Szuchet, S.; Papasozomenos, S.C.; Zinkowski, R.P.; Binder, L.I. Functional implications for the microtubule-associated protein tau: Localization in oligodendrocytes. Proc. Natl. Acad. Sci. USA 1995, 92, 10369-10373. [CrossRef]

10. Müller, R.; Heinrich, M.; Heck, S.; Blohm, D.; Richter-Landsberg, C. Expression of microtubule-associated proteins MAP2 and tau in cultured rat brain oligodendrocytes. Cell Tissue Res. 1997, 288, 239-249. [CrossRef]

11. Komori, T. Tau-positive dial Inclusions in Progressive Supranuclear Palsy, Corticobasal Degeneration and Pick's Disease. Brain Pathol. 1999, 9, 663-679. [CrossRef] [PubMed]

12. Maragakis, N.J.; Rothstein, J.D. Mechanisms of disease: Astrocytes in neurodegenerative disease. Nat. Clin. Pract. Neurol. 2006, 2, 679-689. [CrossRef] [PubMed]

13. Trojanowski, J.Q.; Schuck, T.; Schmidt, M.L.; Lee, V. Distribution of tau proteins in the normal human central and peripheral nervous system. J. Histochem. Cytochem. 1989, 37, 209-215. [CrossRef] [PubMed]

14. Dugger, B.N.; Hoffman, B.R.; Scroggins, A.; Serrano, G.E.; Adler, C.H.; Shill, H.A.; Belden, C.M.; Sabbagh, M.N.; Caviness, J.N.; Dunckley, E.D. Tau immunoreactivity in peripheral tissues of human aging and select tauopathies. Neurosci. Lett. 2019, 696, 132-139. [CrossRef] [PubMed]

15. Goedert, M.; Jakes, R. Expression of separate isoforms of human tau protein: Correlation with the tau pattern in brain and effects on tubulin polymerization. EMBO J. 1990, 9, 4225-4230. [CrossRef]

16. Kosik, K.S.; Orecchio, L.D.; Bakalis, S.; Neve, R.L. Developmentally regulated expression of specific tau sequences. Neuron 1989, 2, 1389-1397. [CrossRef]

17. Buee, L.; Bussiere, T.; Buee-Scherrer, V.; Delacourte, A.; Hof, P.R. Tau protein isoforms, phosphorylation and role in neurodegenerative disorders. Brain Res. Brain Res. Rev. 2000, 33, 95-130. [CrossRef] 
18. Guo, T.; Noble, W.; Hanger, D.P. Roles of tau protein in health and disease. Acta Neuropathol. 2017, 133, 665-704. [CrossRef] [PubMed]

19. Lee, G.; Cowan, N.; Kirschner, M. The primary structure and heterogeneity of tau protein from mouse brain. Science 1988, 239, 285-288. [CrossRef] [PubMed]

20. Kadavath, H.; Hofele, R.V.; Biernat, J.; Kumar, S.; Tepper, K.; Urlaub, H.; Mandelkow, E.; Zweckstetter, M. Tau stabilizes microtubules by binding at the interface between tubulin heterodimers. Proc. Natl. Acad. Sci. USA 2015, 112, 7501-7506. [CrossRef] [PubMed]

21. Dawson, H.N.; Ferreira, A.; Eyster, M.V.; Ghoshal, N.; Binder, L.I.; Vitek, M.P. Inhibition of neuronal maturation in primary hippocampal neurons from tau deficient mice. J. Cell Sci. 2001, 114 Pt 6, 1179-1187. [CrossRef]

22. Harada, A.; Oguchi, K.; Okabe, S.; Kuno, J.; Terada, S.; Ohshima, T.; Sato-Yoshitake, R.; Takei, Y.; Noda, T.; Hirokawa, N. Altered microtubule organization in small-calibre axons of mice lacking tau protein. Nature 1994, 369, 488-491. [CrossRef] [PubMed]

23. Tan, D.C.S.; Yao, S.; Ittner, A.; Bertz, J.; Ke, Y.D.; Ittner, L.M.; Delerue, F. Generation of a New Tau Knockout (tauDeltaex1) Line Using CRISPR/Cas9 Genome Editing in Mice. J. Alzheimer's Dis. 2018, 62, 571-578. [CrossRef]

24. Terwel, D.; Lasrado, R.; Snauwaert, J.; Vandeweert, E.; Van Haesendonck, C.; Borghgraef, P.; Van Leuven, F. Changed conformation of mutant Tau-P301L underlies the moribund tauopathy, absent in progressive, nonlethal axonopathy of Tau- $4 \mathrm{R} / 2 \mathrm{~N}$ transgenic mice. J. Biol. Chem. 2005, 280, 3963-3973. [CrossRef] [PubMed]

25. Tucker, K.L.; Meyer, M.; Barde, Y.A. Neurotrophins are required for nerve growth during development. Nat. Neurosci. 2001, 4, 29-37. [CrossRef]

26. DiTella, M.; Feiguin, F.; Carri, N.; Kosik, K.; Caceres, A. MAP-1B/TAU functional redundancy during laminin-enhanced axonal growth. J. Cell Sci. 1996, 109, 467-477. [CrossRef]

27. Lei, P.; Ayton, S.; Moon, S.; Zhang, Q.; Volitakis, I.; Finkelstein, D.I.; Bush, A.I. Motor and cognitive deficits in aged tau knockout mice in two background strains. Mol. Neurodegener. 2014, 9, 29. [CrossRef]

28. Ahmed, T.; Van der Jeugd, A.; Blum, D.; Galas, M.C.; D’Hooge, R.; Buee, L.; Balschun, D. Cognition and hippocampal synaptic plasticity in mice with a homozygous tau deletion. Neurobiol. Aging 2014, 35, 2474-2478. [CrossRef]

29. Hong, X.P.; Peng, C.X.; Wei, W.; Tian, Q.; Liu, Y.H.; Yao, X.Q.; Zhang, Y.; Cao, F.Y.; Wang, Q.; Wang, J.Z. Essential role of tau phosphorylation in adult hippocampal neurogenesis. Hippocampus 2010, 20, 1339-1349. [CrossRef]

30. Lei, P.; Ayton, S.; Finkelstein, D.I.; Spoerri, L.; Ciccotosto, G.D.; Wright, D.K.; Wong, B.X.; Adlard, P.A.; Cherny, R.A.; Lam, L.Q.; et al. Tau deficiency induces parkinsonism with dementia by impairing APP-mediated iron export. Nat. Med. 2012, 18, 291-295. [CrossRef]

31. Kimura, T.; Whitcomb, D.J.; Jo, J.; Regan, P.; Piers, T.; Heo, S.; Brown, C.; Hashikawa, T.; Murayama, M.; Seok, H.; et al. Microtubule-associated protein tau is essential for long-term depression in the hippocampus. Philos. Trans. R. Soc. Lond. B Biol. Sci. 2014, 369, 20130144. [CrossRef] [PubMed]

32. Regan, P.; Piers, T.; Yi, J.H.; Kim, D.H.; Huh, S.; Park, S.J.; Ryu, J.H.; Whitcomb, D.J.; Cho, K. Tau phosphorylation at serine 396 residue is required for hippocampal LTD. J. Neurosci. 2015, 35, 4804-4812. [CrossRef]

33. Ittner, L.M.; Ke, Y.D.; Delerue, F.; Bi, M.; Gladbach, A.; van Eersel, J.; Wolfing, H.; Chieng, B.C.; Christie, M.J.; Napier, I.A.; et al. Dendritic function of tau mediates amyloid-beta toxicity in Alzheimer's disease mouse models. Cell 2010, 142, 387-397. [CrossRef] [PubMed]

34. Leroy, K.; Ando, K.; Laporte, V.; Dedecker, R.; Suain, V.; Authelet, M.; Heraud, C.; Pierrot, N.; Yilmaz, Z.; Octave, J.N.; et al. Lack of tau proteins rescues neuronal cell death and decreases amyloidogenic processing of APP in APP/PS1 mice. Am. J. Pathol. 2012, 181, 1928-1940. [CrossRef] [PubMed]

35. Roberson, E.D.; Halabisky, B.; Yoo, J.W.; Yao, J.; Chin, J.; Yan, F.; Wu, T.; Hamto, P.; Devidze, N.; Yu, G.Q.; et al. Amyloid-beta/Fyninduced synaptic, network, and cognitive impairments depend on tau levels in multiple mouse models of Alzheimer's disease. J. Neurosci. 2011, 31, 700-711. [CrossRef] [PubMed]

36. Roberson, E.D.; Scearce-Levie, K.; Palop, J.J.; Yan, F.; Cheng, I.H.; Wu, T.; Gerstein, H.; Yu, G.Q.; Mucke, L. Reducing endogenous tau ameliorates amyloid beta-induced deficits in an Alzheimer's disease mouse model. Science 2007, 316, 750-754. [CrossRef]

37. Bi, M.; Gladbach, A.; van Eersel, J.; Ittner, A.; Przybyla, M.; van Hummel, A.; Chua, S.W.; van der Hoven, J.; Lee, W.S.; Muller, J.; et al. Tau exacerbates excitotoxic brain damage in an animal model of stroke. Nat. Commun. 2017, 8, 473. [CrossRef]

38. De Vos, S.L.; Goncharoff, D.K.; Chen, G.; Kebodeaux, C.S.; Yamada, K.; Stewart, F.R.; Schuler, D.R.; Maloney, S.E.; Wozniak, D.F.; Rigo, F.; et al. Antisense reduction of tau in adult mice protects against seizures. J. Neurosci. 2013, 33, 12887-12897. [CrossRef]

39. Gheyara, A.L.; Ponnusamy, R.; Djukic, B.; Craft, R.J.; Ho, K.; Guo, W.; Finucane, M.M.; Sanchez, P.E.; Mucke, L. Tau reduction prevents disease in a mouse model of Dravet syndrome. Ann. Neurol. 2014, 76, 443-456. [CrossRef]

40. Braak, H.; Braak, E. Staging of Alzheimer's disease-related neurofibrillary changes. Neurobiol. Aging 1995, 16, 271-278. [CrossRef]

41. Braak, H.; Braak, E. Neuropathological stageing of Alzheimer-related changes. Acta Neuropathol. 1991, 82, 239-259. [CrossRef]

42. Lin, W.-L.; Lewis, J.; Yen, S.-H.; Hutton, M.; Dickson, D.W. Filamentous tau in oligodendrocytes and astrocytes of transgenic mice expressing the human tau isoform with the P301L mutation. Am. J. Pathol. 2003, 162, 213-218. [CrossRef]

43. Perea, J.R.; López, E.; Díez-Ballesteros, J.C.; Ávila, J.; Hernández, F.; Bolós, M. Extracellular monomeric tau is internalized by astrocytes. Front. Neurosci. 2019, 13, 442. [CrossRef] [PubMed]

44. Kovacs, G.G. Tauopathies. Handb. Clin. Neurol. 2018, 145, 355-368. 
45. De Calignon, A.; Fox, L.M.; Pitstick, R.; Carlson, G.A.; Bacskai, B.J.; Spires-Jones, T.L.; Hyman, B.T. Caspase activation precedes and leads to tangles. Nature 2010, 464, 1201-1204. [CrossRef] [PubMed]

46. Ross, C.A.; Poirier, M.A. Protein aggregation and neurodegenerative disease. Nat. Med. 2004, 10, S10-S17. [CrossRef]

47. Cowan, C.M.; Mudher, A. Are tau aggregates toxic or protective in tauopathies? Front. Neurol. 2013, 4, 114. [CrossRef]

48. Kitazawa, M.; Oddo, S.; Yamasaki, T.R.; Green, K.N.; La Ferla, F.M. Lipopolysaccharide-induced inflammation exacerbates tau pathology by a cyclin-dependent kinase 5-mediated pathway in a transgenic model of Alzheimer's disease. J. Neurosci. 2005, 25, 8843-8853. [CrossRef]

49. Hansen, D.V.; Hanson, J.E.; Sheng, M. Microglia in Alzheimer's disease. J. Cell Biol. 2018, 217, 459-472. [CrossRef]

50. Friedman, B.A.; Srinivasan, K.; Ayalon, G.; Meilandt, W.J.; Lin, H.; Huntley, M.A.; Cao, Y.; Lee, S.-H.; Haddick, P.C.; Ngu, H. Diverse brain myeloid expression profiles reveal distinct microglial activation states and aspects of Alzheimer's disease not evident in mouse models. Cell Rep. 2018, 22, 832-847. [CrossRef]

51. Rademakers, R.; Cruts, M.; van Broeckhoven, C. The role of tau (MAPT) in frontotemporal dementia and related tauopathies. Hum. Mutat. 2004, 24, 277-295. [CrossRef] [PubMed]

52. Tolnay, M.; Probst, A. Argyrophilic grain disease. Handb. Clin. Neurol. 2008, 89, 553-563. [PubMed]

53. Mahapatra, R.K.; Edwards, M.J.; Schott, J.M.; Bhatia, K.P. Corticobasal degeneration. Lancet Neurol. 2004, 3, 736-743. [CrossRef]

54. Arai, T.; Ikeda, K.; Akiyama, H.; Nonaka, T.; Hasegawa, M.; Ishiguro, K.; Iritani, S.; Tsuchiya, K.; Iseki, E.; Yagishita, S.; et al. Identification of amino-terminally cleaved tau fragments that distinguish progressive supranuclear palsy from corticobasal degeneration. Ann. Neurol. 2004, 55, 72-79. [CrossRef]

55. Hauw, J.J.; Verny, M.; Delaere, P.; Cervera, P.; He, Y.; Duyckaerts, C. Constant neurofibrillary changes in the neocortex in progressive supranuclear palsy. Basic differences with Alzheimer's disease and aging. Neurosci. Lett. 1990, 119, 182-186. [CrossRef]

56. Brandt, R.; Léger, J.; Lee, G. Interaction of tau with the neural plasma membrane mediated by tau's amino-terminal projection domain. J. Cell Biol. 1995, 131, 1327-1340. [CrossRef]

57. Brandt, R.; Trushina, N.I.; Bakota, L. Much More Than a Cytoskeletal Protein: Physiological and Pathological Functions of the Non-microtubule Binding Region of Tau. Front. Neurol. 2020, 11, 1-14. [CrossRef]

58. Dixit, R.; Ross, J.L.; Goldman, Y.E.; Holzbaur, E.L. Differential regulation of dynein and kinesin motor proteins by tau. Science 2008, 319, 1086-1089. [CrossRef]

59. Konzack, S.; Thies, E.; Marx, A.; Mandelkow, E.M.; Mandelkow, E. Swimming against the tide: Mobility of the microtubuleassociated protein tau in neurons. J. Neurosci. 2007, 27, 9916-9927. [CrossRef]

60. Utton, M.A.; Noble, W.J.; Hill, J.E.; Anderton, B.H.; Hanger, D.P. Molecular motors implicated in the axonal transport of tau and $\alpha$-synuclein. J. Cell Sci. 2005, 118, 4645-4654. [CrossRef]

61. Magnani, E.; Fan, J.; Gasparini, L.; Golding, M.; Williams, M.; Schiavo, G.; Goedert, M.; Amos, L.A.; Spillantini, M.G. Interaction of tau protein with the dynactin complex. EMBO J. 2007, 26, 4546-4554. [CrossRef]

62. Kobayashi, S.; Tanaka, T.; Soeda, Y.; Takashima, A. Enhanced tau protein translation by hyper-excitation. Front. Aging Neurosci. 2019, 11, 322. [CrossRef] [PubMed]

63. Yamada, K.; Holth, J.K.; Liao, F.; Stewart, F.R.; Mahan, T.E.; Jiang, H.; Cirrito, J.R.; Patel, T.K.; Hochgräfe, K.; Mandelkow, E.-M. Neuronal activity regulates extracellular tau in vivo. J. Exp. Med. 2014, 211, 387-393. [CrossRef]

64. Wang, Y.; Balaji, V.; Kaniyappan, S.; Krüger, L.; Irsen, S.; Tepper, K.; Chandupatla, R.; Maetzler, W.; Schneider, A.; Mandelkow, E. The release and trans-synaptic transmission of Tau via exosomes. Mol. Neurodegener. 2017, 12, 1-25. [CrossRef]

65. Sato, C.; Barthelemy, N.R.; Mawuenyega, K.G.; Patterson, B.W.; Gordon, B.A.; Jockel-Balsarotti, J.; Sullivan, M.; Crisp, M.J.; Kasten, T.; Kirmess, K.M.; et al. Tau Kinetics in Neurons and the Human Central Nervous System. Neuron 2018, 97, 1284-1298.e7. [CrossRef] [PubMed]

66. Pooler, A.M.; Phillips, E.C.; Lau, D.H.; Noble, W.; Hanger, D.P. Physiological release of endogenous tau is stimulated by neuronal activity. EMBO Rep. 2013, 14, 389-394. [CrossRef]

67. Araque, A.; Parpura, V.; Sanzgiri, R.P.; Haydon, P.G. Tripartite synapses: Glia, the unacknowledged partner. Trends Neurosci. 1999, 22, 208-215. [CrossRef]

68. Perea, G.; Navarrete, M.; Araque, A. Tripartite synapses: Astrocytes process and control synaptic information. Trends Neurosci. 2009, 32, 421-431. [CrossRef]

69. Halassa, M.M.; Fellin, T.; Haydon, P.G. The tripartite synapse: Roles for gliotransmission in health and disease. Trends Mol. Med. 2007, 13, 54-63. [CrossRef]

70. Piacentini, R.; Li Puma, D.D.; Mainardi, M.; Lazzarino, G.; Tavazzi, B.; Arancio, O.; Grassi, C. Reduced gliotransmitter release from astrocytes mediates tau-induced synaptic dysfunction in cultured hippocampal neurons. Glia 2017, 65, 1302-1316. [CrossRef] [PubMed]

71. Tremblay, M.-È.; Lowery, R.L.; Majewska, A.K. Microglial interactions with synapses are modulated by visual experience. PLoS Biol. 2010, 8, e1000527. [CrossRef]

72. Wake, H.; Moorhouse, A.J.; Jinno, S.; Kohsaka, S.; Nabekura, J. Resting microglia directly monitor the functional state of synapses in vivo and determine the fate of ischemic terminals. J. Neurosci. 2009, 29, 3974-3980. [CrossRef]

73. Maphis, N.; Xu, G.; Kokiko-Cochran, O.N.; Jiang, S.; Cardona, A.; Ransohoff, R.M.; Lamb, B.T.; Bhaskar, K. Reactive microglia drive tau pathology and contribute to the spreading of pathological tau in the brain. Brain 2015, 138, 1738-1755. [CrossRef] 
74. Mondragon-Rodriguez, S.; Trillaud-Doppia, E.; Dudilot, A.; Bourgeois, C.; Lauzon, M.; Leclerc, N.; Boehm, J. Interaction of endogenous tau protein with synaptic proteins is regulated by N-methyl-D-aspartate receptor-dependent tau phosphorylation. J. Biol. Chem. 2012, 287, 32040-32053. [CrossRef] [PubMed]

75. Tai, H.C.; Serrano-Pozo, A.; Hashimoto, T.; Frosch, M.P.; Spires-Jones, T.L.; Hyman, B.T. The synaptic accumulation of hyperphosphorylated tau oligomers in Alzheimer disease is associated with dysfunction of the ubiquitin-proteasome system. Am. J. Pathol. 2012, 181, 1426-1435. [CrossRef] [PubMed]

76. Suetsugu, S.; Toyooka, K.; Senju, Y. Subcellular Membrane Curvature Mediated by the BAR Domain Superfamily Proteins. Semin. Cell Dev. Biol. 2010, 21, 340-349. [CrossRef]

77. Sinsky, J.; Majerova, P.; Kovac, A.; Kotlyar, M.; Jurisica, I.; Hanes, J. Physiological tau interactome in brain and its link to tauopathies. J. Proteome Res. 2020, 19, 2429-2442. [CrossRef] [PubMed]

78. Safari, F.; Suetsugu, S. The BAR domain superfamily proteins from subcellular structures to human diseases. Membranes 2012, 2, 91-117. [CrossRef]

79. Liu, Y.; Lv, K.; Li, Z.; Yu, A.C.; Chen, J.; Teng, J. PACSIN1, a Tau-interacting protein, regulates axonal elongation and branching by facilitating microtubule instability. J. Biol. Chem. 2012, 287, 39911-39924. [CrossRef]

80. He, H.J.; Wang, X.S.; Pan, R.; Wang, D.L.; Liu, M.N.; He, R.Q. The proline-rich domain of tau plays a role in interactions with actin. BMC Cell Biol. 2009, 10, 1-12. [CrossRef]

81. Elie, A.; Prezel, E.; Guerin, C.; Denarier, E.; Ramirez-Rios, S.; Serre, L.; Andrieux, A.; Fourest-Lieuvin, A.; Blanchoin, L.; Arnal, I. Tau co-organizes dynamic microtubule and actin networks. Sci. Rep. 2015, 5, 9964. [CrossRef]

82. Pallas-Bazarra, N.; Draffin, J.; Cuadros, R.; Antonio Esteban, J.; Avila, J. Tau is required for the function of extrasynaptic NMDA receptors. Sci. Rep. 2019, 9, 9116. [CrossRef] [PubMed]

83. Lu, J.; Li, T.; He, R.; Bartlett, P.F.; Gotz, J. Visualizing the microtubule-associated protein tau in the nucleus. Sci. China Life Sci. 2014, 57, 422-431. [CrossRef] [PubMed]

84. Liu, C.; Gotz, J. Profiling murine tau with $0 \mathrm{~N}, 1 \mathrm{~N}$ and $2 \mathrm{~N}$ isoform-specific antibodies in brain and peripheral organs reveals distinct subcellular localization, with the $1 \mathrm{~N}$ isoform being enriched in the nucleus. PLoS ONE 2013, 8, e84849. [CrossRef] [PubMed]

85. Maina, M.B.; Bailey, L.J.; Wagih, S.; Biasetti, L.; Pollack, S.J.; Quinn, J.P.; Thorpe, J.R.; Doherty, A.J.; Serpell, L.C. The involvement of tau in nucleolar transcription and the stress response. Acta Neuropathol. Commun. 2018, 6, 70. [CrossRef]

86. Sjoberg, M.K.; Shestakova, E.; Mansuroglu, Z.; Maccioni, R.B.; Bonnefoy, E. Tau protein binds to pericentromeric DNA: A putative role for nuclear tau in nucleolar organization. J. Cell Sci. 2006, 119 Pt 10, 2025-2034. [CrossRef]

87. Thurston, V.C.; Zinkowski, R.P.; Binder, L.I. Tau as a nucleolar protein in human nonneural cells in vitro and in vivo. Chromosoma 1996, 105, 20-30. [CrossRef]

88. Wei, Y.; Qu, M.H.; Wang, X.S.; Chen, L.; Wang, D.L.; Liu, Y.; Hua, Q.; He, R.Q. Binding to the minor groove of the double-strand, tau protein prevents DNA from damage by peroxidation. PLoS ONE 2008, 3, e2600. [CrossRef]

89. Kampers, T.; Friedhoff, P.; Biernat, J.; Mandelkow, E.M.; Mandelkow, E. RNA stimulates aggregation of microtubule-associated protein tau into Alzheimer-like paired helical filaments. FEBS Lett. 1996, 399, 344-349. [CrossRef]

90. Violet, M.; Delattre, L.; Tardivel, M.; Sultan, A.; Chauderlier, A.; Caillierez, R.; Talahari, S.; Nesslany, F.; Lefebvre, B.; Bonnefoy, E.; et al. A major role for Tau in neuronal DNA and RNA protection in vivo under physiological and hyperthermic conditions. Front. Cell Neurosci. 2014, 8, 84. [CrossRef]

91. Sultan, A.; Nesslany, F.; Violet, M.; Begard, S.; Loyens, A.; Talahari, S.; Mansuroglu, Z.; Marzin, D.; Sergeant, N.; Humez, S.; et al. Nuclear tau, a key player in neuronal DNA protection. J. Biol. Chem. 2011, 286, 4566-4575. [CrossRef]

92. Mansuroglu, Z.; Benhelli-Mokrani, H.; Marcato, V.; Sultan, A.; Violet, M.; Chauderlier, A.; Delattre, L.; Loyens, A.; Talahari, S.; Begard, S.; et al. Loss of Tau protein affects the structure, transcription and repair of neuronal pericentromeric heterochromatin. Sci. Rep. 2016, 6, 33047. [CrossRef]

93. Qi, H.; Cantrelle, F.X.; Benhelli-Mokrani, H.; Smet-Nocca, C.; Buee, L.; Lippens, G.; Bonnefoy, E.; Galas, M.C.; Landrieu, I. Nuclear magnetic resonance spectroscopy characterization of interaction of Tau with DNA and its regulation by phosphorylation. Biochemistry 2015, 54, 1525-1533. [CrossRef]

94. Eftekharzadeh, B.; Daigle, J.G.; Kapinos, L.E.; Coyne, A.; Schiantarelli, J.; Carlomagno, Y.; Cook, C.; Miller, S.J.; Dujardin, S.; Amaral, A.S. Tau protein disrupts nucleocytoplasmic transport in Alzheimer's disease. Neuron 2018, 99, 925-940.e7. [CrossRef] [PubMed]

95. Goedert, M.; Spillantini, M.; Crowther, R. Cloning of a big tau microtubule-associated protein characteristic of the peripheral nervous system. Proc. Natl. Acad. Sci. USA 1992, 89, 1983-1987. [CrossRef] [PubMed]

96. Taleghany, N.; Oblinger, M. Regional distribution and biochemical characteristics of high molecular weight tau in the nervous system. J. Neurosci. Res. 1992, 33, 257-265. [CrossRef]

97. Fischer, I.; Baas, P.W. Resurrecting the mysteries of big tau. Trends Neurosci. 2020, 43, 493-504. [CrossRef] [PubMed]

98. Mercken, M.; Fischer, I.; Kosik, K.; Nixon, R. Three distinct axonal transport rates for tau, tubulin, and other microtubuleassociated proteins: Evidence for dynamic interactions of tau with microtubules in vivo. J. Neurosci. 1995, 15, 8259-8267. [CrossRef]

99. Boyne, L.; Tessler, A.; Murray, M.; Fischer, I. Distribution of Big tau in the central nervous system of the adult and developing rat. J. Comp. Neurol. 1995, 358, 279-293. [CrossRef] 
100. Frappier, T.F.; Georgieff, I.S.; Brown, K.; Shelanski, M.L. $\tau$ Regulation of Microtubule-Microtubule Spacing and Bundling. J. Neurochem. 1994, 63, 2288-2294. [CrossRef]

101. Kanaan, N.M.; Morfini, G.; Pigino, G.; LaPointe, N.E.; Andreadis, A.; Song, Y.; Leitman, E.; Binder, L.I.; Brady, S.T. Phosphorylation in the amino terminus of tau prevents inhibition of anterograde axonal transport. Neurobiol. Aging 2012, 33, 826.e15-826.e30. [CrossRef] [PubMed]

102. Frost, B.; Jacks, R.L.; Diamond, M.I. Propagation of tau misfolding from the outside to the inside of a cell. J. Biol. Chem. 2009, 284, 12845-12852. [CrossRef]

103. Clavaguera, F.; Duyckaerts, C.; Haïk, S. Prion-like properties of Tau assemblies. Curr. Opin. Neurobiol. 2020, 61, 49-57. [CrossRef]

104. Banati, R.B.; Gehrmann, J.; Schubert, P.; Kreutzberg, G.W. Cytotoxicity of microglia. Glia 1993, 7, 111-118. [CrossRef]

105. Paolicelli, R.C.; Bergamini, G.; Rajendran, L. Cell-to-cell communication by extracellular vesicles: Focus on microglia. Neuroscience 2019, 405, 148-157. [CrossRef] [PubMed]

106. Asai, H.; Ikezu, S.; Tsunoda, S.; Medalla, M.; Luebke, J.; Haydar, T.; Wolozin, B.; Butovsky, O.; Kügler, S.; Ikezu, T. Depletion of microglia and inhibition of exosome synthesis halt tau propagation. Nat. Neurosci. 2015, 18, 1584. [CrossRef]

107. Ebneth, A.; Godemann, R.; Stamer, K.; Illenberger, S.; Trinczek, B.; Mandelkow, E.-M.; Mandelkow, E. Overexpression of tau protein inhibits kinesin-dependent trafficking of vesicles, mitochondria, and endoplasmic reticulum: Implications for Alzheimer's disease. J. Cell Biol. 1998, 143, 777-794. [CrossRef]

108. Denk, F.; Wade-Martins, R. Knock-out and transgenic mouse models of tauopathies. Neurobiol. Aging 2009, 30, 1-13. [CrossRef]

109. Blair, L.J.; Frauen, H.D.; Zhang, B.; Nordhues, B.A.; Bijan, S.; Lin, Y.-C.; Zamudio, F.; Hernandez, L.D.; Sabbagh, J.J.; Selenica, M.-L.B. Tau depletion prevents progressive blood-brain barrier damage in a mouse model of tauopathy. Acta Neuropathol. Commun. 2015, 3, 1-22. [CrossRef]

110. Ledesma, M.D.; Bonay, P.; Avila, J. $\tau$ Protein from Alzheimer's disease patients is glycated at its tubulin-binding domain. J. Neurochem. 1995, 65, 1658-1664. [CrossRef]

111. Du Yan, S.; Yan, S.F.; Chen, X.; Fu, J.; Chen, M.; Kuppusamy, P.; Smith, M.A.; Perry, G.; Godman, G.C.; Nawroth, P. Nonenzymatically glycated tau in Alzheimer's disease induces neuronal oxidant stress resulting in cytokine gene expression and release of amyloid $\beta$-peptide. Nat. Med. 1995, 1, 693-699. [CrossRef]

112. Gamblin, T.C.; Chen, F.; Zambrano, A.; Abraha, A.; Lagalwar, S.; Guillozet, A.L.; Lu, M.; Fu, Y.; Garcia-Sierra, F.; LaPointe, N. Caspase cleavage of tau: Linking amyloid and neurofibrillary tangles in Alzheimer's disease. Proc. Natl. Acad. Sci. USA 2003, 100, 10032-10037. [CrossRef]

113. Rissman, R.A.; Poon, W.W.; Blurton-Jones, M.; Oddo, S.; Torp, R.; Vitek, M.P.; LaFerla, F.M.; Rohn, T.T.; Cotman, C.W. Caspasecleavage of tau is an early event in Alzheimer disease tangle pathology. J. Clin. Investig. 2004, 114, 121-130. [CrossRef] [PubMed]

114. Jadhav, S.; Zilka, N.; Novak, M. Protein truncation as a common denominator of human neurodegenerative foldopathies. Mol. Neurobiol. 2013, 48, 516-532. [CrossRef] [PubMed]

115. Guo, Q.; Xie, J. AATF inhibits aberrant production of amyloid $\beta$ peptide 1-42 by interacting directly with Par-4. J. Biol. Chem. 2004, 279, 4596-4603. [CrossRef] [PubMed]

116. Köpke, E.; Tung, Y.-C.; Shaikh, S.; Alonso, A.d.C.; Iqbal, K.; Grundke-Iqbal, I. Microtubule-associated protein tau. Abnormal phosphorylation of a non-paired helical filament pool in Alzheimer disease. J. Biol. Chem. 1993, 268, 24374-24384. [CrossRef]

117. Novak, M. Truncated tau protein as a new marker for Alzheimer's disease. Acta Virol. 1994, 38, 173-189. [PubMed]

118. Yen, S.-h.; Liu, W.-K.; Hall, F.L.; Yan, S.-D.; Stern, D.; Dickson, D.W. Alzheimer neurofibrillary lesions: Molecular nature and potential roles of different components. Neurobiol. Aging 1995, 16, 381-387. [CrossRef]

119. Armstrong, R.A.; Lantos, P.L.; Cairns, N.J. What determines the molecular composition of abnormal protein aggregates in neurodegenerative disease? Neuropathology 2008, 28, 351-365. [CrossRef]

120. Goldman, R.D.; Steinert, P.M. Cellular and Molecular Biology of Intermediate Filaments; Springer Science \& Business Media: New York, NY, USA, 2013.

121. Samson, A.L.; Ho, B.; Au, A.E.; Schoenwaelder, S.M.; Smyth, M.J.; Bottomley, S.P.; Kleifeld, O.; Medcalf, R.L. Physicochemical properties that control protein aggregation also determine whether a protein is retained or released from necrotic cells. Open Biol. 2016, 6, 160098. [CrossRef]

122. Kosik, K.S.; Duffy, L.K.; Dowling, M.M.; Abraham, C.; McCluskey, A.; Selkoe, D.J. Microtubule-associated protein 2: Monoclonal antibodies demonstrate the selective incorporation of certain epitopes into Alzheimer neurofibrillary tangles. Proc. Natl. Acad. Sci. USA 1984, 81, 7941-7945. [CrossRef]

123. Hasegawa, M.; Arai, T.; Ihara, Y. Immunochemical evidence that fragments of phosphorylated MAP5 (MAP1B) are bound to neurofibrillary tangles in Alzheimer's disease. Neuron 1990, 4, 909-918. [CrossRef]

124. Takahashi, H.; Hirokawa, K.; Ando, S.; Obata, K. Immunohistological study on brains of Alzheimer's disease using antibodies to fetal antigens, C-series gangliosides and microtubule-associated protein 5. Acta Neuropathol. 1991, 81, 626-631. [CrossRef]

125. Anderton, B.H.; Breinburg, D.; Downes, M.J.; Green, P.J.; Tomlinson, B.; Ulrich, J.; Wood, J.N.; Kahn, J. Monoclonal antibodies show that neurofibrillary tangles and neurofilaments share antigenic determinants. Nature 1982, 298, 84-86. [CrossRef]

126. Snow, A.; Mar, H.; Nochlin, D.; Sekiguchi, R.; Kimata, K.; Koike, Y.; Wight, T. Early accumulation of heparan sulfate in neurons and in the beta-amyloid protein-containing lesions of Alzheimer's disease and Down's syndrome. Am. J. Pathol. 1990, 137, 1253. 
127. Perry, G.; Siedlak, S.L.; Richey, P.; Kawai, M.; Cras, P.; Kalaria, R.N.; Galloway, P.G.; Scardina, J.M.; Cordell, B.; Greenberg, B.D. Association of heparan sulfate proteoglycan with the neurofibrillary tangles of Alzheimer's disease. J. Neurosci. 1991, 11, 3679-3683. [CrossRef]

128. Huang, Y.; Herman, M.M.; Liu, J.; Katsetos, C.D.; Wills, M.R.; Savory, J. Neurofibrillary lesions in experimental aluminum-induced encephalopathy and Alzheimer's disease share immunoreactivity for amyloid precursor protein, $A \beta, \alpha 1$-antichymotrypsin and ubiquitin-protein conjugates. Brain Res. 1997, 771, 213-220. [CrossRef]

129. Perry, G.; Richey, P.L.; Siedlak, S.L.; Smith, M.A.; Mulvihill, P.; DeWitt, D.A.; Barnett, J.; Greenberg, B.D.; Kalaria, R.N. Immunocytochemical evidence that the beta-protein precursor is an integral component of neurofibrillary tangles of Alzheimer's disease. Am. J. Pathol. 1993, 143, 1586. [PubMed]

130. Baum, L.; Masliah, E.; Iimoto, D.S.; Hansen, L.A.; Halliday, W.C.; Saitoh, T. Casein kinase II is associated with neurofibrillary tangles but is not an intrinsic component of paired helical filaments. Brain Res. 1992, 573, 126-132. [CrossRef]

131. Trojanowski, J.Q.; Mawal-Dewan, M.; Schmidt, M.L.; Martin, J.; Lee, V.M.-Y. Localization of the mitogen activated protein kinase ERK2 in Alzheimer's disease neurofibrillary tangles and senile plaque neurites. Brain Res. 1993, 618, 333-337. [CrossRef]

132. Hanger, D.P.; Hughes, K.; Woodgett, J.R.; Brion, J.-P.; Anderton, B.H. Glycogen synthase kinase-3 induces Alzheimer's disease-like phosphorylation of tau: Generation of paired helical filament epitopes and neuronal localisation of the kinase. Neurosci. Lett. 1992, 147, 58-62. [CrossRef]

133. Shimohama, S.; Homma, Y.; Suenaga, T.; Fujimoto, S.; Taniguchi, T.; Araki, W.; Yamaoka, Y.; Takenawa, T.; Kimura, J. Aberrant accumulation of phospholipase C-delta in Alzheimer brains. Am. J. Pathol. 1991, 139, 737.

134. Smith, M.A.; Taneda, S.; Richey, P.L.; Miyata, S.; Yan, S.-D.; Stern, D.; Sayre, L.M.; Monnier, V.M.; Perry, G. Advanced Maillard reaction end products are associated with Alzheimer disease pathology. Proc. Natl. Acad. Sci. USA 1994, 91, 5710-5714. [CrossRef]

135. Yan, S.; Chen, X.; Schmidt, A.; Brett, J.; Godman, G.; Zou, Y.; Scott, C.; Caputo, C.; Frappier, T.; Smith, M. Glycated tau protein in Alzheimer disease: A mechanism for induction of oxidant stress. Proc. Natl. Acad. Sci. USA 1994, 91, 7787-7791. [CrossRef]

136. Sasaki, N.; Fukatsu, R.; Tsuzuki, K.; Hayashi, Y.; Yoshida, T.; Fujii, N.; Koike, T.; Wakayama, I.; Yanagihara, R.; Garruto, R. Advanced glycation end products in Alzheimer's disease and other neurodegenerative diseases. Am. J. Pathol. 1998, 153, 1149-1155. [CrossRef]

137. Gella, A.; Durany, N. Oxidative stress in Alzheimer disease. Cell Adhes. Migr. 2009, 3, 88-93. [CrossRef] [PubMed]

138. McGeer, P.; Akiyama, H.; Itagaki, S.; McGeer, E. Activation of the classical complement pathway in brain tissue of Alzheimer patients. Neurosci. Lett. 1989, 107, 341-346. [CrossRef]

139. Itagaki, S.; Akiyama, H.; Saito, H.; McGeer, P.L. Ultrastructural localization of complement membrane attack complex (MAC)-like immunoreactivity in brains of patients with Alzheimer's disease. Brain Res. 1994, 645, 78-84. [CrossRef]

140. Akiyama, H.; Kawamata, T.; Dedhar, S.; McGeer, P. Immunohistochemical localization of vitronectin, its receptor and beta-3 integrin in Alzheimer brain tissue. J. Neuroimmunol. 1991, 32, 19-28. [CrossRef]

141. Namba, Y.; Tomonaga, M.; Kawasaki, H.; Otomo, E.; Ikeda, K. Apolipoprotein E immunoreactivity in cerebral amyloid deposits and neurofibrillary tangles in Alzheimer's disease and kuru plaque amyloid in Creutzfeldt-Jakob disease. Brain Res. 1991, 541, 163-166. [CrossRef]

142. Yamaguchi, H.; Nakazato, Y.; Shoji, M.; Okamoto, K.; Ihara, Y.; Morimatsu, M.; Hirai, S. Secondary deposition of beta amyloid within extracellular neurofibrillary tangles in Alzheimer-type dementia. Am. J. Pathol. 1991, 138, 699.

143. Mori, H.; Kondo, J.; Ihara, Y. Ubiquitin is a component of paired helical filaments in Alzheimer's disease. Science 1987, 235, 1641-1644. [CrossRef]

144. Iwatsubo, T.; Hasegawa, M.; Esaki, Y.; Ihara, Y. Lack of ubiquitin immunoreactivities at both ends of neuropil threads. Possible bidirectional growth of neuropil threads. Am. J. Pathol. 1992, 140, 277.

145. Nakamura, M.; Kaneko, S.; Dickson, D.W.; Kusaka, H. Aberrant accumulation of BRCA1 in Alzheimer disease and other tauopathies. J. Neuropathol. Exp. Neurol. 2020, 79, 22-33. [CrossRef] [PubMed]

146. Arima, K.; Nakamura, M.; Sunohara, N.; Nishio, T.; Ogawa, M.; Hirai, S.; Kawai, M.; Ikeda, K. Immunohistochemical and ultrastructural characterization of neuritic clusters around ghost tangles in the hippocampal formation in progressive supranuclear palsy brains. Acta Neuropathol. 1999, 97, 565-576. [CrossRef] [PubMed]

147. Kalaria, R.; Golde, T.; Kroon, S.; Perry, G. Serine protease inhibitor antithrombin III and its messenger RNA in the pathogenesis of Alzheimer's disease. Am. J. Pathol. 1993, 143, 886. [PubMed]

148. Kawamata, T.; Tooyama, I.; Yamada, T.; Walker, D.G.; McGeer, P.L. Lactotransferrin immunocytochemistry in Alzheimer and normal human brain. Am. J. Pathol. 1993, 142, 1574. [PubMed]

149. Oughtred, R.; Rust, J.; Chang, C.; Breitkreutz, B.J.; Stark, C.; Willems, A.; Boucher, L.; Leung, G.; Kolas, N.; Zhang, F. The BioGRID database: A comprehensive biomedical resource of curated protein, genetic, and chemical interactions. Protein Sci. 2021, 30, 187-200. [CrossRef]

150. Fahey, M.E.; Bennett, M.J.; Mahon, C.; Jäger, S.; Pache, L.; Kumar, D.; Shapiro, A.; Rao, K.; Chanda, S.K.; Craik, C.S. GPS-Prot: A web-based visualization platform for integrating host-pathogen interaction data. BMC Bioinform. 2011, 12, 1-13. [CrossRef]

151. Salwinski, L.; Miller, C.S.; Smith, A.J.; Pettit, F.K.; Bowie, J.U.; Eisenberg, D. The database of interacting proteins: 2004 update. Nucleic Acids Res. 2004, 32 (Suppl. 1), D449-D451. [CrossRef] 
152. Orchard, S.; Ammari, M.; Aranda, B.; Breuza, L.; Briganti, L.; Broackes-Carter, F.; Campbell, N.H.; Chavali, G.; Chen, C.; Del-Toro, N. The MIntAct project-IntAct as a common curation platform for 11 molecular interaction databases. Nucleic Acids Res. 2014, 42, D358-D363. [CrossRef]

153. Licata, L.; Briganti, L.; Peluso, D.; Perfetto, L.; Iannuccelli, M.; Galeota, E.; Sacco, F.; Palma, A.; Nardozza, A.P.; Santonico, E. MINT, the molecular interaction database: 2012 update. Nucleic Acids Res. 2012, 40, D857-D861. [CrossRef] [PubMed]

154. Szklarczyk, D.; Gable, A.L.; Lyon, D.; Junge, A.; Wyder, S.; Huerta-Cepas, J.; Simonovic, M.; Doncheva, N.T.; Morris, J.H.; Bork, P. STRING v11: Protein-protein association networks with increased coverage, supporting functional discovery in genome-wide experimental datasets. Nucleic Acids Res. 2019, 47, D607-D613. [CrossRef] [PubMed]

155. Kotlyar, M.; Pastrello, C.; Malik, Z.; Jurisica, I. IID 2018 update: Context-specific physical protein-protein interactions in human, model organisms and domesticated species. Nucleic Acids Res. 2019, 47, D581-D589. [CrossRef] [PubMed]

156. Ksiezak-Reding, H.; Liu, W.-K.; Yen, S.-H. Phosphate analysis and dephosphorylation of modified tau associated with paired helical filaments. Brain Res. 1992, 597, 209-219. [CrossRef]

157. Biernat, J.; Gustke, N.; Drewes, G.; Mandelkow, E.M.; Mandelkow, E. Phosphorylation of Ser262 strongly reduces binding of tau to microtubules: Distinction between PHF-like immunoreactivity and microtubule binding. Neuron 1993, 11, 153-163. [CrossRef]

158. Goedert, M.; Jakes, R.; Crowther, R.A.; Cohen, P.; Vanmechelen, E.; Vandermeeren, M.; Cras, P. Epitope mapping of monoclonal antibodies to the paired helical filaments of Alzheimer's disease: Identification of phosphorylation sites in tau protein. Biochem. J. 1994, 301 Pt 3, 871-877. [CrossRef]

159. Zheng-Fischhofer, Q.; Biernat, J.; Mandelkow, E.M.; Illenberger, S.; Godemann, R.; Mandelkow, E. Sequential phosphorylation of Tau by glycogen synthase kinase-3beta and protein kinase A at Thr212 and Ser214 generates the Alzheimer-specific epitope of antibody AT100 and requires a paired-helical-filament-like conformation. Eur. J. Biochem. 1998, 252, 542-552. [CrossRef] [PubMed]

160. Wegmann, S.; Biernat, J.; Mandelkow, E. A current view on Tau protein phosphorylation in Alzheimer's disease. Curr. Opin. Neurobiol. 2021, 69, 131-138. [CrossRef]

161. Hasegawa, M.; Morishima-Kawashima, M.; Takio, K.; Suzuki, M.; Titani, K.A.; Ihara, Y. Protein sequence and mass spectrometric analyses of tau in the Alzheimer's disease brain. J. Biol. Chem. 1992, 267, 17047-17054. [CrossRef]

162. Brici, D.; Götz, J.; Nisbet, R.M. A novel antibody targeting tau phosphorylated at serine 235 detects neurofibrillary tangles. J. Alzheimer's Dis. 2018, 61, 899-905. [CrossRef] [PubMed]

163. Neddens, J.; Temmel, M.; Flunkert, S.; Kerschbaumer, B.; Hoeller, C.; Loeffler, T.; Niederkofler, V.; Daum, G.; Attems, J.; Hutter-Paier, B. Phosphorylation of different tau sites during progression of Alzheimer's disease. Acta Neuropathol. Commun. 2018, 6, 1-15. [CrossRef]

164. Hanger, D.P.; Betts, J.C.; Loviny, T.L.; Blackstock, W.P.; Anderton, B.H. New phosphorylation sites identified in hyperphosphorylated tau (paired helical filament-tau) from Alzheimer's disease brain using nanoelectrospray mass spectrometry. J. Neurochem. 1998, 71, 2465-2476. [CrossRef] [PubMed]

165. Matsuo, E.S.; Shin, R.W.; Billingsley, M.L.; Van deVoorde, A.; O’Connor, M.; Trojanowski, J.Q.; Lee, V.M. Biopsy-derived adult human brain tau is phosphorylated at many of the same sites as Alzheimer's disease paired helical filament tau. Neuron 1994, 13, 989-1002. [CrossRef]

166. Drepper, F.; Biernat, J.; Kaniyappan, S.; Meyer, H.E.; Mandelkow, E.M.; Warscheid, B.; Mandelkow, E. A combinatorial native MS and LC-MS/MS approach reveals high intrinsic phosphorylation of human Tau but minimal levels of other key modifications. J. Biol. Chem. 2020, 295, 18213-18225. [CrossRef]

167. Mair, W.; Muntel, J.; Tepper, K.; Tang, S.; Biernat, J.; Seeley, W.W.; Kosik, K.S.; Mandelkow, E.; Steen, H.; Steen, J.A. FLEXITau: Quantifying post-translational modifications of tau protein in vitro and in human disease. Anal. Chem. 2016, 88, 3704-3714. [CrossRef]

168. Tepper, K.; Biernat, J.; Kumar, S.; Wegmann, S.; Timm, T.; Hübschmann, S.; Redecke, L.; Mandelkow, E.-M.; Müller, D.J.; Mandelkow, E. Oligomer formation of tau protein hyperphosphorylated in cells. J. Biol. Chem. 2014, 289, 34389-34407. [CrossRef]

169. Martin, L.; Latypova, X.; Wilson, C.M.; Magnaudeix, A.; Perrin, M.-L.; Yardin, C.; Terro, F. Tau protein kinases: Involvement in Alzheimer's disease. Ageing Res. Rev. 2013, 12, 289-309. [CrossRef]

170. Liu, F.; Grundke-Iqbal, I.; Iqbal, K.; Gong, C.X. Contributions of protein phosphatases PP1, PP2A, PP2B and PP5 to the regulation of tau phosphorylation. Eur. J. Neurosci. 2005, 22, 1942-1950. [CrossRef]

171. Martin, L.; Latypova, X.; Wilson, C.M.; Magnaudeix, A.; Perrin, M.-L.; Terro, F. Tau protein phosphatases in Alzheimer's disease: The leading role of PP2A. Ageing Res. Rev. 2013, 12, 39-49. [CrossRef]

172. Alvarez, A.R.; Sandoval, P.C.; Leal, N.R.; Castro, P.U.; Kosik, K.S. Activation of the neuronal c-Abl tyrosine kinase by amyloid- $\beta$ peptide and reactive oxygen species. Neurobiol. Dis. 2004, 17, 326-336. [CrossRef]

173. Franke, T.F.; Kaplan, D.R.; Cantley, L.C. PI3K: Downstream AKTion blocks apoptosis. Cell 1997, 88, 435-437. [CrossRef]

174. Litersky, J.M.; Johnson, G.V.; Jakes, R.; Goedert, M.; Lee, M.; Seubert, P. Tau protein is phosphorylated by cyclic AMP-dependent protein kinase and calcium/calmodulin-dependent protein kinase II within its microtubule-binding domains at Ser-262 and Ser-356. Biochem. J. 1996, 316, 655-660. [CrossRef]

175. Singh, T.J.; Wang, J.-Z.; Novak, M.; Kontzekova, E.; Grundke-Iqbal, I.; Iqbal, K. Calcium/calmodulin-dependent protein kinase II phosphorylates tau at Ser-262 but only partially inhibits its binding to microtubules. FEBS Lett. 1996, 387, 145-148. [CrossRef] 
176. Patrick, G.N.; Zukerberg, L.; Nikolic, M.; de La Monte, S.; Dikkes, P.; Tsai, L.-H. Conversion of p35 to p25 deregulates Cdk5 activity and promotes neurodegeneration. Nature 1999, 402, 615-622. [CrossRef]

177. Piedrahita, D.; Hernández, I.; López-Tobón, A.; Fedorov, D.; Obara, B.; Manjunath, B.; Boudreau, R.L.; Davidson, B.; LaFerla, F.; Gallego-Gómez, J.C. Silencing of CDK5 reduces neurofibrillary tangles in transgenic Alzheimer's mice. J. Neurosci. 2010, 30, 13966-13976. [CrossRef] [PubMed]

178. Amniai, L.; Barbier, P.; Sillen, A.; Wieruszeski, J.-M.; Peyrot, V.; Lippens, G.; Landrieu, I. Alzheimer disease specific phosphoepitopes of Tau interfere with assembly of tubulin but not binding to microtubules. FASEB J. 2009, 23, 1146-1152. [CrossRef] [PubMed]

179. Flajolet, M.; He, G.; Heiman, M.; Lin, A.; Nairn, A.C.; Greengard, P. Regulation of Alzheimer's disease amyloid- $\beta$ formation by casein kinase I. Proc. Natl. Acad. Sci. USA 2007, 104, 4159-4164. [CrossRef] [PubMed]

180. Schwab, C.; DeMaggio, A.J.; Ghoshal, N.; Binder, L.I.; Kuret, J.; McGeer, P.L. Casein kinase 1 delta is associated with pathological accumulation of tau in several neurodegenerative diseases. Neurobiol. Aging 2000, 21, 503-510. [CrossRef]

181. Kimura, R.; Kamino, K.; Yamamoto, M.; Nuripa, A.; Kida, T.; Kazui, H.; Hashimoto, R.; Tanaka, T.; Kudo, T.; Yamagata, H. The DYRK1A gene, encoded in chromosome 21 Down syndrome critical region, bridges between $\beta$-amyloid production and tau phosphorylation in Alzheimer disease. Hum. Mol. Genet. 2007, 16, 15-23. [CrossRef] [PubMed]

182. Ryoo, S.-R.; Jeong, H.K.; Radnaabazar, C.; Yoo, J.-J.; Cho, H.-J.; Lee, H.-W.; Kim, I.-S.; Cheon, Y.-H.; Ahn, Y.S.; Chung, S.-H. DYRK1A-mediated Hyperphosphorylation of Tau. J. Biol. Chem. 2007, 282, 34850-34857. [CrossRef]

183. Taira, N.; Nihira, K.; Yamaguchi, T.; Miki, Y.; Yoshida, K. DYRK2 is targeted to the nucleus and controls p53 via Ser46 phosphorylation in the apoptotic response to DNA damage. Mol. Cell 2007, 25, 725-738. [CrossRef]

184. Briner, A.; Götz, J.; Polanco, J.C. Fyn kinase controls tau aggregation in vivo. Cell Rep. 2020, 32, 108045. [CrossRef]

185. Li, C.; Götz, J. Pyk2 is a novel tau tyrosine kinase that is regulated by the tyrosine kinase fyn. J. Alzheimer's Dis. 2018, 64, 205-221. [CrossRef]

186. Chin, J.; Palop, J.J.; Yu, G.-Q.; Kojima, N.; Masliah, E.; Mucke, L. Fyn kinase modulates synaptotoxicity, but not aberrant sprouting, in human amyloid precursor protein transgenic mice. J. Neurosci. 2004, 24, 4692-4697. [CrossRef] [PubMed]

187. Takashima, A. GSK-3 is essential in the pathogenesis of Alzheimer's disease. J. Alzheimer's Dis. 2006, 9, 309-317. [CrossRef] [PubMed]

188. Hernández, F.; de Barreda, E.G.; Fuster-Matanzo, A.; Lucas, J.J.; Avila, J. GSK3: A possible link between beta amyloid peptide and tau protein. Exp. Neurol. 2010, 223, 322-325. [CrossRef] [PubMed]

189. Mines, M.A.; Beurel, E.; Jope, R.S. Regulation of cell survival mechanisms in Alzheimer's disease by glycogen synthase kinase-3. Int. J. Alzheimer's Dis. 2011, 2011. [CrossRef] [PubMed]

190. Hata, R.; Masumura, M.; Akatsu, H.; Li, F.; Fujita, H.; Nagai, Y.; Yamamoto, T.; Okada, H.; Kosaka, K.; Sakanaka, M. Up-regulation of calcineurin A $\beta$ mRNA in the Alzheimer's disease brain: Assessment by cDNA microarray. Biochem. Biophys. Res. Commun. 2001, 284, 310-316. [CrossRef] [PubMed]

191. Scales, T.M.; Derkinderen, P.; Leung, K.-Y.; Byers, H.L.; Ward, M.A.; Price, C.; Bird, I.N.; Perera, T.; Kellie, S.; Williamson, R. Tyrosine phosphorylation of tau by the SRC family kinases lck and fyn. Mol. Neurodegener. 2011, 6, 1-11. [CrossRef]

192. Ujiie, S.; Hatano, T.; Kubo, S.-I.; Imai, S.; Sato, S.; Uchihara, T.; Yagishita, S.; Hasegawa, K.; Kowa, H.; Sakai, F. LRRK2 I2020T mutation is associated with tau pathology. Parkinsonism Relat. Disord. 2012, 18, 819-823. [CrossRef] [PubMed]

193. Ohta, E.; Nihira, T.; Uchino, A.; Imaizumi, Y.; Okada, Y.; Akamatsu, W.; Takahashi, K.; Hayakawa, H.; Nagai, M.; Ohyama, M. I2020T mutant LRRK2 iPSC-derived neurons in the Sagamihara family exhibit increased Tau phosphorylation through the AKT/GSK-3ß signaling pathway. Hum. Mol. Genet. 2015, 24, 4879-4900. [CrossRef] [PubMed]

194. Henderson, M.X.; Changolkar, L.; Trojanowski, J.Q.; Lee, V.M. LRRK2 Kinase Activity Does Not Alter Cell-Autonomous Tau Pathology Development in Primary Neurons. J. Parkinson's Dis. 2021, 11, 1187-1196. [CrossRef] [PubMed]

195. Bailey, R.M.; Covy, J.P.; Melrose, H.L.; Rousseau, L.; Watkinson, R.; Knight, J.; Miles, S.; Farrer, M.J.; Dickson, D.W.; Giasson, B.I. LRRK2 phosphorylates novel tau epitopes and promotes tauopathy. Acta Neuropathol. 2013, 126, 809-827. [CrossRef] [PubMed]

196. Zhu, X.; Raina, A.K.; Rottkamp, C.A.; Aliev, G.; Perry, G.; Boux, H.; Smith, M.A. Activation and redistribution of c-jun N-terminal kinase/stress activated protein kinase in degenerating neurons in Alzheimer's disease. J. Neurochem. 2001, 76, 435-441. [CrossRef]

197. Shen, C.; Chen, Y.; Liu, H.; Zhang, K.; Zhang, T.; Lin, A.; Jing, N. Hydrogen peroxide promotes A $\beta$ production through JNK-dependent activation of $\gamma$-secretase. J. Biol. Chem. 2008, 283, 17721-17730. [CrossRef] [PubMed]

198. Atzori, C.; Ghetti, B.; Piva, R.; Srinivasan, A.N.; Zolo, P.; Delisle, M.B.; Mirra, S.S.; Migheli, A. Activation of the JNK/p38 pathway occurs in diseases characterized by tau protein pathology and is related to tau phosphorylation but not to apoptosis. J. Neuropathol. Exp. Neurol. 2001, 60, 1190-1197. [CrossRef]

199. Swatton, J.E.; Sellers, L.A.; Faull, R.L.; Holland, A.; Iritani, S.; Bahn, S. Increased MAP kinase activity in Alzheimer's and Down syndrome but not in schizophrenia human brain. Eur. J. Neurosci. 2004, 19, 2711-2719. [CrossRef]

200. Chin, J.Y.; Knowles, R.B.; Schneider, A.; Drewes, G.; Mandelkow, E.-M.; Hyman, B.T. Microtubule-affinity regulating kinase (MARK) is tightly associated with neurofibrillary tangles in Alzheimer brain: A fluorescence resonance energy transfer study. J. Neuropathol. Exp. Neurol. 2000, 59, 966-971. [CrossRef]

201. Oba, T.; Saito, T.; Asada, A.; Shimizu, S.; Iijima, K.M.; Ando, K. MARK4 with an Alzheimer's disease-related mutation promotes tau hyperphosphorylation directly and indirectly and exacerbates neurodegeneration. bioRxiv 2020. [CrossRef] 
202. Kawamata, T.; Taniguchi, T.; Mukai, H.; Kitagawa, M.; Hashimoto, T.; Maeda, K.; Ono, Y.; Tanaka, C. A protein kinase, PKN, accumulates in Alzheimer neurofibrillary tangles and associated endoplasmic reticulum-derived vesicles and phosphorylates tau protein. J. Neurosci. 1998, 18, 7402-7410. [CrossRef] [PubMed]

203. Taniguchi, T.; Kawamata, T.; Mukai, H.; Hasegawa, H.; Isagawa, T.; Yasuda, M.; Hashimoto, T.; Terashima, A.; Nakai, M.; Ono, Y. Phosphorylation of tau is regulated by PKN. J. Biol. Chem. 2001, 276, 10025-10031. [CrossRef] [PubMed]

204. Jensen, P.H.; Hager, H.; Nielsen, M.S.; Højrup, P.; Gliemann, J.; Jakes, R. $\alpha$-Synuclein binds to tau and stimulates the protein kinase A-catalyzed tau phosphorylation of serine residues 262 and 356. J. Biol. Chem. 1999, 274, 25481-25489. [CrossRef] [PubMed]

205. Liu, S.J.; Zhang, J.Y.; Li, H.L.; Fang, Z.Y.; Wang, Q.; Deng, H.M.; Gong, C.X.; Grundke-Iqbal, I.; Iqbal, K.; Wang, J.Z. Tau becomes a more favorable substrate for GSK-3 when it is prephosphorylated by PKA in rat brain. J. Biol. Chem. 2004, 279, 50078-50088 [CrossRef]

206. Jicha, G.A.; Weaver, C.; Lane, E.; Vianna, C.; Kress, Y.; Rockwood, J.; Davies, P. cAMP-dependent protein kinase phosphorylations on tau in Alzheimer's disease. J. Neurosci. 1999, 19, 7486-7494. [CrossRef]

207. Shi, J.; Qian, W.; Yin, X.; Iqbal, K.; Grundke-Iqbal, I.; Gu, X.; Ding, F.; Gong, C.-X.; Liu, F. Cyclic AMP-dependent protein kinase regulates the alternative splicing of tau exon 10: A mechanism involved in tau pathology of Alzheimer disease. J. Biol. Chem. 2011, 286, 14639-14648. [CrossRef]

208. Wang, Z.F.; Li, H.L.; Li, X.C.; Zhang, Q.; Tian, Q.; Wang, Q.; Xu, H.; Wang, J.Z. Effects of endogenous $\beta$-amyloid overproduction on tau phosphorylation in cell culture. J. Neurochem. 2006, 98, 1167-1175. [CrossRef]

209. Isagawa, T.; Mukai, H.; Oishi, K.; Taniguchi, T.; Hasegawa, H.; Kawamata, T.; Tanaka, C.; Ono, Y. Dual effects of PKN $\alpha$ and protein kinase $\mathrm{C}$ on phosphorylation of tau protein by glycogen synthase kinase-3ß. Biochem. Biophys. Res. Commun. 2000, 273, 209-212. [CrossRef]

210. Dourlen, P.; Fernandez-Gomez, F.; Dupont, C.; Grenier-Boley, B.; Bellenguez, C.; Obriot, H.; Caillierez, R.; Sottejeau, Y.; Chapuis, J.; Bretteville, A. Functional screening of Alzheimer risk loci identifies PTK2B as an in vivo modulator and early marker of Tau pathology. Mol. Psychiatry 2017, 22, 874-883. [CrossRef]

211. Caccamo, A.; Branca, C.; Talboom, J.S.; Shaw, D.M.; Turner, D.; Ma, L.; Messina, A.; Huang, Z.; Wu, J.; Oddo, S. Reducing ribosomal protein S6 kinase 1 expression improves spatial memory and synaptic plasticity in a mouse model of Alzheimer's disease. J. Neurosci. 2015, 35, 14042-14056. [CrossRef]

212. An, W.-L.; Cowburn, R.F.; Li, L.; Braak, H.; Alafuzoff, I.; Iqbal, K.; Iqbal, I.-G.; Winblad, B.; Pei, J.-J. Up-regulation of phosphorylated/activated p70 S6 kinase and its relationship to neurofibrillary pathology in Alzheimer's disease. Am. J. Pathol. 2003, 163, 591-607. [CrossRef]

213. Pei, J.-J.; Björkdahl, C.; Zhang, H.; Zhou, X.; Winblad, B. p70 S6 kinase and tau in Alzheimer's disease. J. Alzheimer's Dis. 2008, 14, 385-392. [CrossRef]

214. Elahi, M.; Motoi, Y.; Shimonaka, S.; Ishiguro, K.; Imai, Y.; Hattori, N. High-fat diet-induced activation of SGK1 contributes to Alzheimer's disease pathogenesis by promoting tau pathology. bioRxiv 2020. [CrossRef]

215. Liu, F.; Gong, C.-X. Tau exon 10 alternative splicing and tauopathies. Mol. Neurodegener. 2008, 3, 1-10. [CrossRef] [PubMed]

216. Zhang, Y.; Wu, F.; Iqbal, K.; Gong, C.-X.; Hu, W.; Liu, F. Subacute to chronic Alzheimer-like alterations after controlled cortical impact in human tau transgenic mice. Sci. Rep. 2019, 9, 1-13. [CrossRef] [PubMed]

217. Schweig, J.E.; Yao, H.; Beaulieu-Abdelahad, D.; Ait-Ghezala, G.; Mouzon, B.; Crawford, F.; Mullan, M.; Paris, D. Alzheimer's disease pathological lesions activate the spleen tyrosine kinase. Acta Neuropathol. Commun. 2017, 5, 1-25. [CrossRef]

218. Schweig, J.E.; Yao, H.; Jin, C.; Crawford, F.; Mullan, M.; Paris, D. Neuronal Spleen tyrosine kinase (SYK) mediates cytokine release in Transgenic Tau P301S mice organotypic brain slice cultures. Neurosci. Lett. 2020, 729, 134992. [CrossRef] [PubMed]

219. Schweig, J.E.; Yao, H.; Coppola, K.; Jin, C.; Crawford, F.; Mullan, M.; Paris, D. Spleen tyrosine kinase (SYK) blocks autophagic Tau degradation in vitro and in vivo. J. Biol. Chem. 2019, 294, 13378-13395. [CrossRef]

220. Xu, J.; Sato, S.; Okuyama, S.; Swan, R.J.; Jacobsen, M.T.; Strunk, E.; Ikezu, T. Tau-tubulin kinase 1 enhances prefibrillar tau aggregation and motor neuron degeneration in P301L FTDP-17 tau-mutant mice. FASEB J. 2010, 24, 2904-2915. [CrossRef]

221. Dillon, G.M.; Henderson, J.L.; Bao, C.; Joyce, J.A.; Calhoun, M.; Amaral, B.; King, K.W.; Bajrami, B.; Rabah, D. Acute inhibition of the CNS-specific kinase TTBK1 significantly lowers tau phosphorylation at several disease relevant sites. PLoS ONE 2020, 15, e0228771. [CrossRef]

222. Gong, C.X.; Singh, T.J.; Grundke-Iqbal, I.; Iqbal, K. Phosphoprotein phosphatase activities in Alzheimer disease brain. J. Neurochem. 1993, 61, 921-927. [CrossRef] [PubMed]

223. Kins, S.; Crameri, A.; Evans, D.R.; Hemmings, B.A.; Nitsch, R.M.; Götz, J. Reduced protein phosphatase 2A activity induces hyperphosphorylation and altered compartmentalization of tau in transgenic mice. J. Biol. Chem. 2001, 276, 38193-38200. [CrossRef] [PubMed]

224. McKenzie-Nickson, S.; Chan, J.; Perez, K.; Hung, L.W.; Cheng, L.; Sedjahtera, A.; Gunawan, L.; Adlard, P.A.; Hayne, D.J.; McInnes, L.E. Modulating protein phosphatase 2A rescues disease phenotype in neurodegenerative tauopathies. ACS Chem. Neurosci. 2018, 9, 2731-2740. [CrossRef] [PubMed]

225. Sanchez-Ortiz, E.; Hahm, B.K.; Armstrong, D.L.; Rossie, S. Protein phosphatase 5 protects neurons against amyloid- $\beta$ toxicity. J. Neurochem. 2009, 111, 391-402. [CrossRef]

226. Gong, C.X.; Liu, F.; Wu, G.; Rossie, S.; Wegiel, J.; Li, L.; Grundke-Iqbal, I.; Iqbal, K. Dephosphorylation of microtubule-associated protein tau by protein phosphatase 5. J. Neurochem. 2004, 88, 298-310. [CrossRef] 
227. Liu, F.; Iqbal, K.; Grundke-Iqbal, I.; Rossie, S.; Gong, C.-X. Dephosphorylation of tau by protein phosphatase 5: Impairment in Alzheimer's disease. J. Biol. Chem. 2005, 280, 1790-1796. [CrossRef]

228. Kim, Y.; Liu, G.; Leugers, C.J.; Mueller, J.D.; Francis, M.B.; Hefti, M.M.; Schneider, J.A.; Lee, G. Tau interacts with SHP2 in neuronal systems and in Alzheimer's disease brains. J. Cell Sci. 2019, 132, jcs229054. [CrossRef]

229. Chao, Y.; Xing, Y.; Chen, Y.; Xu, Y.; Lin, Z.; Li, Z.; Jeffrey, P.D.; Stock, J.B.; Shi, Y. Structure and mechanism of the phosphotyrosyl phosphatase activator. Mol. Cell 2006, 23, 535-546. [CrossRef]

230. Luo, Y.; Nie, Y.-J.; Shi, H.-R.; Ni, Z.-F.; Wang, Q.; Wang, J.-Z.; Liu, G.-P. PTPA activates protein phosphatase-2A through reducing its phosphorylation at tyrosine-307 with upregulation of protein tyrosine phosphatase 1B. Biochim. Biophys. Acta Mol. Cell Res. 2013, 1833, 1235-1243. [CrossRef]

231. Jinwal, U.K.; Trotter, J.H.; Abisambra, J.F.; Koren, J.; Lawson, L.Y.; Vestal, G.D.; O'Leary, J.C.; Johnson, A.G.; Jin, Y.; Jones, J.R. The Hsp90 kinase co-chaperone Cdc37 regulates tau stability and phosphorylation dynamics. J. Biol. Chem. 2011, 286, 16976-16983. [CrossRef]

232. Cheng, W.; Chen, W.; Wang, P.; Chu, J. Asiatic acid protects differentiated PC12 cells from A $\beta 25-35$-induced apoptosis and tau hyperphosphorylation via regulating PI3K/Akt/GSK-3ß signaling. Life Sci. 2018, 208, 96-101. [CrossRef]

233. Malek-Ahmadi, M.; Beach, T.; Obradov, A.; Sue, L.; Belden, C.; Davis, K.; Walker, D.G.; Lue, L.; Adem, A.; Sabbagh, M.N. Increased Alzheimer's disease neuropathology is associated with type 2 diabetes and ApoE $\varepsilon 4$ carrier status. Curr. Alzheimer Res. 2013, 10, 654-659. [CrossRef]

234. Curtis, D.; Bakaya, K.; Sharma, L.; Bandyopadhyay, S. Weighted burden analysis of exome-sequenced late-onset Alzheimer's cases and controls provides further evidence for a role for PSEN1 and suggests involvement of the PI3K/Akt/GSK-3 $\beta$ and WNT signalling pathways. Ann. Hum. Genet. 2020, 84, 291-302. [CrossRef] [PubMed]

235. Reynolds, C.H.; Garwood, C.J.; Wray, S.; Price, C.; Kellie, S.; Perera, T.; Zvelebil, M.; Yang, A.; Sheppard, P.W.; Varndell, I.M.; et al. Phosphorylation regulates tau interactions with Src homology 3 domains of phosphatidylinositol 3-kinase, phospholipase Cgamma1, Grb2, and Src family kinases. J. Biol. Chem. 2008, 283, 18177-18186. [CrossRef]

236. Baudier, J.; Cole, R.D. Interactions between the microtubule-associated tau proteins and S100b regulate tau phosphorylation by the Ca2+/calmodulin-dependent protein kinase II. J. Biol. Chem. 1988, 263, 5876-5883. [CrossRef]

237. Yamaguchi, F.; Umeda, Y.; Shimamoto, S.; Tsuchiya, M.; Tokumitsu, H.; Tokuda, M.; Kobayashi, R. S100 proteins modulate protein phosphatase 5 function: A link between CA2+ signal transduction and protein dephosphorylation. J. Biol. Chem. 2012, 287, 13787-13798. [CrossRef] [PubMed]

238. Huttunen, H.J.; Kuja-Panula, J.; Sorci, G.; Agneletti, A.L.; Donato, R.; Rauvala, H. Coregulation of neurite outgrowth and cell survival by amphoterin and S100 proteins through receptor for advanced glycation end products (RAGE) activation. J. Biol. Chem. 2000, 275, 40096-40105. [CrossRef]

239. Esposito, G.; Scuderi, C.; Lu, J.; Savani, C.; De Filippis, D.; Iuvone, T.; Steardo, L., Jr.; Sheen, V.; Steardo, L. S100B induces tau protein hyperphosphorylation via Dickopff-1 up-regulation and disrupts the Wnt pathway in human neural stem cells. J. Cell. Mol. Med. 2008, 12, 914-927. [CrossRef]

240. Van Eldik, L.J.; Wainwright, M.S. The Janus face of glial-derived S100B: Beneficial and detrimental functions in the brain. Restor. Neurol. Neurosci. 2003, 21, 97-108.

241. Brown, J.L.; Roberts, W.K. Evidence that approximately eighty per cent of the soluble proteins from Ehrlich ascites cells are Nalpha-acetylated. J. Biol. Chem. 1976, 251, 1009-1014. [CrossRef]

242. Allfrey, V.G.; Mirsky, A.E. Structural Modifications of Histones and their Possible Role in the Regulation of RNA Synthesis. Science 1964, 144, 559. [CrossRef] [PubMed]

243. Levenson, J.M.; O’Riordan, K.J.; Brown, K.D.; Trinh, M.A.; Molfese, D.L.; Sweatt, J.D. Regulation of histone acetylation during memory formation in the hippocampus. J. Biol. Chem. 2004, 279, 40545-40559. [CrossRef] [PubMed]

244. Behnia, R.; Panic, B.; Whyte, J.R.; Munro, S. Targeting of the Arf-like GTPase Arl3p to the Golgi requires N-terminal acetylation and the membrane protein Sys1p. Nat. Cell Biol. 2004, 6, 405-413. [CrossRef] [PubMed]

245. Scott, D.C.; Monda, J.K.; Bennett, E.J.; Harper, J.W.; Schulman, B.A. N-terminal acetylation acts as an avidity enhancer within an interconnected multiprotein complex. Science 2011, 334, 674-678. [CrossRef]

246. Ferreon, J.C.; Jain, A.; Choi, K.-J.; Tsoi, P.S.; MacKenzie, K.R.; Jung, S.Y.; Ferreon, A.C. Acetylation disfavors tau phase separation. Int. J. Mol. Sci. 2018, 19, 1360. [CrossRef]

247. Cohen, T.J.; Guo, J.L.; Hurtado, D.E.; Kwong, L.K.; Mills, I.P.; Trojanowski, J.Q.; Lee, V.M. The acetylation of tau inhibits its function and promotes pathological tau aggregation. Nat. Commun. 2011, 2, 252. [CrossRef]

248. Cohen, T.J.; Friedmann, D.; Hwang, A.W.; Marmorstein, R.; Lee, V.M. The microtubule-associated tau protein has intrinsic acetyltransferase activity. Nat. Struct. Mol. Biol. 2013, 20, 756-762. [CrossRef]

249. Irwin, D.J.; Cohen, T.J.; Grossman, M.; Arnold, S.E.; Xie, S.X.; Lee, V.M.; Trojanowski, J.Q. Acetylated tau, a novel pathological signature in Alzheimer's disease and other tauopathies. Brain 2012, 135 Pt 3, 807-818. [CrossRef]

250. Min, S.W.; Cho, S.H.; Zhou, Y.; Schroeder, S.; Haroutunian, V.; Seeley, W.W.; Huang, E.J.; Shen, Y.; Masliah, E.; Mukherjee, C.; et al. Acetylation of tau inhibits its degradation and contributes to tauopathy. Neuron 2010, 67, 953-966. [CrossRef]

251. Cohen, T.J.; Constance, B.H.; Hwang, A.W.; James, M.; Yuan, C.-X. Intrinsic tau acetylation is coupled to auto-proteolytic tau fragmentation. PLoS ONE 2016, 11, e0158470. [CrossRef] [PubMed] 
252. Cook, C.; Carlomagno, Y.; Gendron, T.F.; Dunmore, J.; Scheffel, K.; Stetler, C.; Davis, M.; Dickson, D.; Jarpe, M.; DeTure, M.; et al. Acetylation of the KXGS motifs in tau is a critical determinant in modulation of tau aggregation and clearance. Hum. Mol. Genet. 2014, 23, 104-116. [CrossRef] [PubMed]

253. Ding, H.; Dolan, P.J.; Johnson, G.V. Histone deacetylase 6 interacts with the microtubule-associated protein tau. J. Neurochem. 2008, 106, 2119-2130. [CrossRef]

254. Ogryzko, V.V.; Schiltz, R.L.; Russanova, V.; Howard, B.H.; Nakatani, Y. The transcriptional coactivators p300 and CBP are histone acetyltransferases. Cell 1996, 87, 953-959. [CrossRef]

255. Chen, H.; Lin, R.J.; Xie, W.; Wilpitz, D.; Evans, R.M. Regulation of hormone-induced histone hyperacetylation and gene activation via acetylation of an acetylase. Cell 1999, 98, 675-686. [CrossRef]

256. Rouaux, C.; Jokic, N.; Mbebi, C.; Boutillier, S.; Loeffler, J.P.; Boutillier, A.L. Critical loss of CBP/p300 histone acetylase activity by caspase-6 during neurodegeneration. EMBO J. 2003, 22, 6537-6549. [CrossRef]

257. Verdel, A.; Curtet, S.; Brocard, M.-P.; Rousseaux, S.; Lemercier, C.; Yoshida, M.; Khochbin, S. Active maintenance of mHDA2/mHDAC6 histone-deacetylase in the cytoplasm. Curr. Biol. 2000, 10, 747-749. [CrossRef]

258. Sen, A.; Nelson, T.J.; Alkon, D.L. ApoE4 and A $\beta$ oligomers reduce BDNF expression via HDAC nuclear translocation. J. Neurosci. 2015, 35, 7538-7551. [CrossRef] [PubMed]

259. Parmigiani, R.; Xu, W.; Venta-Perez, G.; Erdjument-Bromage, H.; Yaneva, M.; Tempst, P.; Marks, P. HDAC6 is a specific deacetylase of peroxiredoxins and is involved in redox regulation. Proc. Natl. Acad. Sci. USA 2008, 105, 9633-9638. [CrossRef]

260. Cook, C.; Gendron, T.F.; Scheffel, K.; Carlomagno, Y.; Dunmore, J.; DeTure, M.; Petrucelli, L. Loss of HDAC6, a novel CHIP substrate, alleviates abnormal tau accumulation. Hum. Mol. Genet. 2012, 21, 2936-2945. [CrossRef] [PubMed]

261. Zhang, B.; West, E.J.; Van, K.C.; Gurkoff, G.G.; Zhou, J.; Zhang, X.-M.; Kozikowski, A.P.; Lyeth, B.G. HDAC inhibitor increases histone $\mathrm{H} 3$ acetylation and reduces microglia inflammatory response following traumatic brain injury in rats. Brain Res. 2008, 1226, 181-191. [CrossRef] [PubMed]

262. Kim, H.J.; Rowe, M.; Ren, M.; Hong, J.S.; Chen, P.S.; Chuang, D.M. Histone deacetylase inhibitors exhibit anti-inflammatory and neuroprotective effects in a rat permanent ischemic model of stroke: Multiple mechanisms of action. J Pharm. Exp. 2007, 321, 892-901. [CrossRef] [PubMed]

263. Vaziri, H.; Dessain, S.K.; Ng Eaton, E.; Imai, S.I.; Frye, R.A.; Pandita, T.K.; Guarente, L.; Weinberg, R.A. hSIR2(SIRT1) functions as an NAD-dependent p53 deacetylase. Cell 2001, 107, 149-159. [CrossRef]

264. Langley, E.; Pearson, M.; Faretta, M.; Bauer, U.M.; Frye, R.A.; Minucci, S.; Pelicci, P.G.; Kouzarides, T. Human SIR2 deacetylates p53 and antagonizes PML/p53-induced cellular senescence. EMBO J. 2002, 21, 2383-2396. [CrossRef]

265. Julien, C.; Tremblay, C.; Emond, V.; Lebbadi, M.; Salem, N., Jr.; Bennett, D.A.; Calon, F. Sirtuin 1 reduction parallels the accumulation of tau in Alzheimer disease. J. Neuropathol. Exp. Neurol. 2009, 68, 48-58. [CrossRef] [PubMed]

266. Zakhary, S.M.; Ayubcha, D.; Dileo, J.N.; Jose, R.; Leheste, J.R.; Horowitz, J.M.; Torres, G. Distribution analysis of deacetylase SIRT1 in rodent and human nervous systems. Anat. Rec. 2010, 293, 1024-1032. [CrossRef]

267. Pallas, M.; Pizarro, J.G.; Gutierrez-Cuesta, J.; Crespo-Biel, N.; Alvira, D.; Tajes, M.; Yeste-Velasco, M.; Folch, J.; Canudas, A.M.; Sureda, F.X.; et al. Modulation of SIRT1 expression in different neurodegenerative models and human pathologies. Neuroscience 2008, 154, 1388-1397. [CrossRef]

268. Min, S.W.; Sohn, P.D.; Li, Y.; Devidze, N.; Johnson, J.R.; Krogan, N.J.; Masliah, E.; Mok, S.A.; Gestwicki, J.E.; Gan, L. SIRT1 Deacetylates Tau and Reduces Pathogenic Tau Spread in a Mouse Model of Tauopathy. J. Neurosci. 2018, 38, 3680-3688. [CrossRef]

269. Gao, J.; Wang, W.Y.; Mao, Y.W.; Graff, J.; Guan, J.S.; Pan, L.; Mak, G.; Kim, D.; Su, S.C.; Tsai, L.H. A novel pathway regulates memory and plasticity via SIRT1 and miR-134. Nature 2010, 466, 1105-1109. [CrossRef]

270. Lazarus, B.D.; Love, D.C.; Hanover, J.A. Recombinant O-GlcNAc transferase isoforms: Identification of O-GlcNAcase, yes tyrosine kinase, and tau as isoform-specific substrates. Glycobiology 2006, 16, 415-421. [CrossRef] [PubMed]

271. Kreppel, L.K.; Blomberg, M.A.; Hart, G.W. Dynamic glycosylation of nuclear and cytosolic proteins. Cloning and characterization of a unique O-GlcNAc transferase with multiple tetratricopeptide repeats. J. Biol. Chem. 1997, 272, 9308-9315. [CrossRef]

272. Yu, C.H.; Si, T.; Wu, W.H.; Hu, J.; Du, J.T.; Zhao, Y.F.; Li, Y.M. O-GlcNAcylation modulates the self-aggregation ability of the fourth microtubule-binding repeat of tau. Biochem. Biophys. Res. Commun. 2008, 375, 59-62. [CrossRef] [PubMed]

273. Liu, F.; Iqbal, K.; Grundke-Iqbal, I.; Hart, G.W.; Gong, C.-X. O-GlcNAcylation regulates phosphorylation of tau: A mechanism involved in Alzheimer's disease. Proc. Natl. Acad. Sci. USA 2004, 101, 10804-10809. [CrossRef] [PubMed]

274. Kato, T.; Inui, Y.; Nakamura, A.; Ito, K. Brain fluorodeoxyglucose (FDG) PET in dementia. Ageing Res. Rev. 2016, 30, 73-84. [CrossRef] [PubMed]

275. Lim, S.; Haque, M.M.; Nam, G.; Ryoo, N.; Rhim, H.; Kim, Y.K. Monitoring of Intracellular Tau Aggregation Regulated by OGA/OGT Inhibitors. Int. J. Mol. Sci. 2015, 16, 20212-20224. [CrossRef] [PubMed]

276. Koga, H.; Kaushik, S.; Cuervo, A.M. Protein homeostasis and aging: The importance of exquisite quality control. Ageing Res. Rev. 2011, 10, 205-215. [CrossRef]

277. Morawe, T.; Hiebel, C.; Kern, A.; Behl, C. Protein homeostasis, aging and Alzheimer's disease. Mol. Neurobiol. 2012, 46, 41-54. [CrossRef]

278. Glickman, M.H.; Ciechanover, A. The ubiquitin-proteasome proteolytic pathway: Destruction for the sake of construction. Physiol. Rev. 2002, 82, 373-428. [CrossRef] [PubMed]

279. Dikic, I.; Robertson, M. Ubiquitin ligases and beyond. BMC Biol. 2012, 10, 22. [CrossRef] 
280. Shimura, H.; Schwartz, D.; Gygi, S.P.; Kosik, K.S. CHIP-Hsc70 complex ubiquitinates phosphorylated tau and enhances cell survival. J. Biol. Chem. 2004, 279, 4869-4876. [CrossRef]

281. Kanack, A.; Vittal, V.; Haver, H.; Keppel, T.; Gundry, R.L.; Klevit, R.E.; Scaglione, K.M. UbcH5 Interacts with Substrates to Participate in Lysine Selection with the E3 Ubiquitin Ligase CHIP. Biochemistry 2020, 59, 2078-2088. [CrossRef]

282. Ye, Y.; Klenerman, D.; Finley, D. N-terminal ubiquitination of amyloidogenic proteins triggers removal of their oligomers by the proteasome holoenzyme. J. Mol. Biol. 2020, 432, 585-596. [CrossRef]

283. Ravalin, M.; Theofilas, P.; Basu, K.; Opoku-Nsiah, K.A.; Assimon, V.A.; Medina-Cleghorn, D.; Chen, Y.F.; Bohn, M.F.; Arkin, M.; Grinberg, L.T.; et al. Specificity for latent C termini links the E3 ubiquitin ligase CHIP to caspases. Nat. Chem. Biol. 2019, 15, 786-794. [CrossRef]

284. Vittal, V.; Shi, L.; Wenzel, D.M.; Scaglione, K.M.; Duncan, E.D.; Basrur, V.; Elenitoba-Johnson, K.S.; Baker, D.; Paulson, H.L.; Brzovic, P.S.; et al. Intrinsic disorder drives N-terminal ubiquitination by Ube2w. Nat. Chem. Biol. 2015, 11, 83-89. [CrossRef] [PubMed]

285. Petrucelli, L.; Dickson, D.; Kehoe, K.; Taylor, J.; Snyder, H.; Grover, A.; De Lucia, M.; McGowan, E.; Lewis, J.; Prihar, G.; et al. CHIP and Hsp70 regulate tau ubiquitination, degradation and aggregation. Hum. Mol. Genet. 2004, 13, 703-714. [CrossRef] [PubMed]

286. Moore, D.J.; West, A.B.; Dikeman, D.A.; Dawson, V.L.; Dawson, T.M. Parkin mediates the degradation-independent ubiquitination of Hsp70. J. Neurochem. 2008, 105, 1806-1819. [CrossRef] [PubMed]

287. Sassone, J.; Serratto, G.; Valtorta, F.; Silani, V.; Passafaro, M.; Ciammola, A. The synaptic function of parkin. Brain 2017, 140, 2265-2272. [CrossRef]

288. Singh, K.; Han, K.; Tilve, S.; Wu, K.; Geller, H.M.; Sack, M.N. Parkin targets NOD2 to regulate astrocyte endoplasmic reticulum stress and inflammation. Glia 2018, 66, 2427-2437. [CrossRef]

289. Williams, E.T.; Glauser, L.; Tsika, E.; Jiang, H.; Islam, S.; Moore, D.J. Parkin mediates the ubiquitination of VPS35 and modulates retromer-dependent endosomal sorting. Hum. Mol. Genet. 2018, 27, 3189-3205. [CrossRef] [PubMed]

290. Sun, T.; Ding, W.; Xu, T.; Ao, X.; Yu, T.; Li, M.; Liu, Y.; Zhang, X.; Hou, L.; Wang, J. Parkin Regulates Programmed Necrosis and Myocardial Ischemia/Reperfusion Injury by Targeting Cyclophilin-D. Antioxid. Redox Signal. 2019, 31, 1177-1193. [CrossRef]

291. Hatakeyama, S.; Matsumoto, M.; Kamura, T.; Murayama, M.; Chui, D.H.; Planel, E.; Takahashi, R.; Nakayama, K.I.; Takashima, A. U-box protein carboxyl terminus of Hsc70-interacting protein (CHIP) mediates poly-ubiquitylation preferentially on four-repeat Tau and is involved in neurodegeneration of tauopathy. J. Neurochem. 2004, 91, 299-307. [CrossRef]

292. Flach, K.; Ramminger, E.; Hilbrich, I.; Arsalan-Werner, A.; Albrecht, F.; Herrmann, L.; Goedert, M.; Arendt, T.; Holzer, M. Axotrophin/MARCH7 acts as an E3 ubiquitin ligase and ubiquitinates tau protein in vitro impairing microtubule binding. Biochim. Biophys. Acta 2014, 1842, 1527-1538. [CrossRef]

293. Babu, J.R.; Geetha, T.; Wooten, M.W. Sequestosome 1/p62 shuttles polyubiquitinated tau for proteasomal degradation. J. Neurochem. 2005, 94, 192-203. [CrossRef] [PubMed]

294. Wang, T.; Wang, W.; Wang, Q.; Xie, R.; Landay, A.; Chen, D. The E3 ubiquitin ligase CHIP in normal cell function and in disease conditions. Ann. N. Y. Acad. Sci. 2020, 1460, 3-10. [CrossRef]

295. Rui, Y.-N.; Xu, Z.; Patel, B.; Chen, Z.; Chen, D.; Tito, A.; David, G.; Sun, Y.; Stimming, E.F.; Bellen, H.J. Huntingtin functions as a scaffold for selective macroautophagy. Nat. Cell Biol. 2015, 17, 262-275. [CrossRef] [PubMed]

296. Geetha, T.; Jiang, J.; Wooten, M.W. Lysine 63 polyubiquitination of the nerve growth factor receptor TrkA directs internalization and signaling. Mol. Cell 2005, 20, 301-312. [CrossRef]

297. Wooten, M.W.; Geetha, T.; Seibenhener, M.L.; Babu, J.R.; Diaz-Meco, M.T.; Moscat, J. The p62 scaffold regulates nerve growth factor-induced NF-kappaB activation by influencing TRAF6 polyubiquitination. J. Biol. Chem. 2005, 280, 35625-35629. [CrossRef]

298. Seibenhener, M.L.; Geetha, T.; Wooten, M.W. Sequestosome 1/p62-more than just a scaffold. FEBS Lett. 2007, 581, 175-179. [CrossRef]

299. Bjørkøy, G.; Lamark, T.; Brech, A.; Outzen, H.; Perander, M.; Øvervatn, A.; Stenmark, H.; Johansen, T. p62/SQSTM1 forms protein aggregates degraded by autophagy and has a protective effect on huntingtin-induced cell death. J. Cell Biol. 2005, 171, 603-614. [CrossRef] [PubMed]

300. Clausen, T.H.; Lamark, T.; Isakson, P.; Finley, K.; Larsen, K.B.; Brech, A.; Overvatn, A.; Stenmark, H.; Bjorkoy, G.; Simonsen, A.; et al. p62/SQSTM1 and ALFY interact to facilitate the formation of p62 bodies/ALIS and their degradation by autophagy. Autophagy 2010, 6, 330-344. [CrossRef]

301. Hori, T.; Osaka, F.; Chiba, T.; Miyamoto, C.; Okabayashi, K.; Shimbara, N.; Kato, S.; Tanaka, K. Covalent modification of all members of human cullin family proteins by NEDD8. Oncogene 1999, 18, 6829-6834. [CrossRef]

302. Kamitani, T.; Kito, K.; Fukuda-Kamitani, T.; Yeh, E.T. Targeting of NEDD8 and its conjugates for proteasomal degradation by NUB1. J. Biol. Chem. 2001, 276, 46655-46660. [CrossRef]

303. Richet, E.; Pooler, A.M.; Rodriguez, T.; Novoselov, S.S.; Schmidtke, G.; Groettrup, M.; Hanger, D.P.; Cheetham, M.E.; van der Spuy, J. NUB1 modulation of GSK3beta reduces tau aggregation. Hum. Mol. Genet. 2012, 21, 5254-5267. [CrossRef]

304. Guarascio, R.; Salih, D.; Yasvoina, M.; Edwards, F.A.; Cheetham, M.E.; van der Spuy, J. Negative Regulator of Ubiquitin-Like Protein 1 modulates the autophagy-lysosomal pathway via p62 to facilitate the extracellular release of tau following proteasome impairment. Hum. Mol. Genet. 2020, 29, 80-96. [CrossRef]

305. Bukau, B.; Horwich, A.L. The Hsp70 and Hsp60 chaperone machines. Cell 1998, 92, 351-366. [CrossRef] 
306. Tavaria, M.; Gabriele, T.; Kola, I.; Anderson, R.L. A hitchhiker's guide to the human Hsp70 family. Cell Stress Chaperones 1996, 1, 23-28. [CrossRef]

307. Jinwal, U.K.; Akoury, E.; Abisambra, J.F.; O’Leary III, J.C.; Thompson, A.D.; Blair, L.J.; Jin, Y.; Bacon, J.; Nordhues, B.A.; Cockman, M. Imbalance of Hsp70 family variants fosters tau accumulation. FASEB J. 2013, 27, 1450-1459. [CrossRef] [PubMed]

308. Liu, Z.-C.; Fu, Z.-Q.; Song, J.; Zhang, J.-Y.; Wei, Y.-P.; Chu, J.; Han, L.; Qu, N.; Wang, J.-Z.; Tian, Q. Bip enhanced the association of GSK-3 $\beta$ with tau during ER stress both in vivo and in vitro. J. Alzheimer's Dis. 2012, 29, 727-740. [CrossRef] [PubMed]

309. Sarkar, M.; Kuret, J.; Lee, G. Two motifs within the tau microtubule-binding domain mediate its association with the hsc70 molecular chaperone. J. Neurosci. Res. 2008, 86, 2763-2773. [CrossRef]

310. Rauch, J.N.; Zuiderweg, E.R.; Gestwicki, J.E. Non-canonical Interactions between Heat Shock Cognate Protein 70 (Hsc70) and Bcl2-associated Anthanogene (BAG) Co-Chaperones Are Important for Client Release. J. Biol. Chem. 2016, $291,19848-19857$. [CrossRef]

311. Elliott, E.; Tsvetkov, P.; Ginzburg, I. BAG-1 associates with Hsc70.Tau complex and regulates the proteasomal degradation of Tau protein. J. Biol. Chem. 2007, 282, 37276-37284. [CrossRef]

312. Patterson, K.R.; Ward, S.M.; Combs, B.; Voss, K.; Kanaan, N.M.; Morfini, G.; Brady, S.T.; Gamblin, T.C.; Binder, L.I. Heat shock protein 70 prevents both tau aggregation and the inhibitory effects of preexisting tau aggregates on fast axonal transport. Biochemistry 2011, 50, 10300-10310. [CrossRef]

313. Abisambra, J.F.; Jinwal, U.K.; Suntharalingam, A.; Arulselvam, K.; Brady, S.; Cockman, M.; Jin, Y.; Zhang, B.; Dickey, C.A. DnaJA1 antagonizes constitutive Hsp70-mediated stabilization of tau. J. Mol. Biol. 2012, 421, 653-661. [CrossRef] [PubMed]

314. Young, J.C.; Hartl, F.U. Chaperones and transcriptional regulation by nuclear receptors. Nat. Struct. Biol. 2002, 9, 640-642. [CrossRef] [PubMed]

315. Oroz, J.; Chang, B.J.; Wysoczanski, P.; Lee, C.-T.; Pérez-Lara, Á.; Chakraborty, P.; Hofele, R.V.; Baker, J.D.; Blair, L.J.; Biernat, J. Structure and pro-toxic mechanism of the human Hsp90/PPIase/Tau complex. Nat. Commun. 2018, 9, 1-13. [CrossRef] [PubMed]

316. Fontaine, S.N.; Rauch, J.N.; Nordhues, B.A.; Assimon, V.A.; Stothert, A.R.; Jinwal, U.K.; Sabbagh, J.J.; Chang, L.; Stevens, S.M.; Zuiderweg, E.R. Isoform-selective genetic inhibition of constitutive cytosolic Hsp70 activity promotes client tau degradation using an altered co-chaperone complement. J. Biol. Chem. 2015, 290, 13115-13127. [CrossRef]

317. Ali, Y.O.; Allen, H.M.; Yu, L.; Li-Kroeger, D.; Bakhshizadehmahmoudi, D.; Hatcher, A.; McCabe, C.; Xu, J.; Bjorklund, N.; Taglialatela, G. NMNAT2: HSP90 complex mediates proteostasis in proteinopathies. PLoS Biol. 2016, 14, e1002472. [CrossRef] [PubMed]

318. Jinwal, U.K.; Koren, J.; Borysov, S.I.; Schmid, A.B.; Abisambra, J.F.; Blair, L.J.; Johnson, A.G.; Jones, J.R.; Shults, C.L.; O’Leary, J.C. The Hsp90 cochaperone, FKBP51, increases Tau stability and polymerizes microtubules. J. Neurosci. 2010, 30, 591-599. [CrossRef]

319. Woodford, M.R.; Sager, R.A.; Marris, E.; Dunn, D.M.; Blanden, A.R.; Murphy, R.L.; Rensing, N.; Shapiro, O.; Panaretou, B.; Prodromou, C.; et al. Tumor suppressor Tsc1 is a new Hsp90 co-chaperone that facilitates folding of kinase and non-kinase clients. EMBO J. 2017, 36, 3650-3665. [CrossRef]

320. Tortosa, E.; Santa-Maria, I.; Moreno, F.; Lim, F.; Perez, M.; Avila, J. Binding of Hsp90 to tau promotes a conformational change and aggregation of tau protein. J. Alzheimer's Dis. 2009, 17, 319-325. [CrossRef]

321. Blair, L.J.; Nordhues, B.A.; Hill, S.E.; Scaglione, K.M.; O’Leary, J.C.; Fontaine, S.N.; Breydo, L.; Zhang, B.; Li, P.; Wang, L. Accelerated neurodegeneration through chaperone-mediated oligomerization of tau. J. Clin. Investig. 2013, 123, 4158-4169. [CrossRef]

322. Shelton, L.B.; Baker, J.D.; Zheng, D.; Sullivan, L.E.; Solanki, P.K.; Webster, J.M.; Sun, Z.; Sabbagh, J.J.; Nordhues, B.A.; Koren, J. Hsp90 activator Aha1 drives production of pathological tau aggregates. Proc. Natl. Acad. Sci. USA 2017, 114, 9707-9712. [CrossRef]

323. Freilich, R.; Betegon, M.; Tse, E.; Mok, S.-A.; Julien, O.; Agard, D.A.; Southworth, D.R.; Takeuchi, K.; Gestwicki, J.E. Competing protein-protein interactions regulate binding of Hsp27 to its client protein tau. Nat. Commun. 2018, 9, 1-11. [CrossRef] [PubMed]

324. Shimura, H.; Miura-Shimura, Y.; Kosik, K.S. Binding of tau to heat shock protein 27 leads to decreased concentration of hyperphosphorylated tau and enhanced cell survival. J. Biol. Chem. 2004, 279, 17957-17962. [CrossRef] [PubMed]

325. Poon, S.; Easterbrook-Smith, S.B.; Rybchyn, M.S.; Carver, J.A.; Wilson, M.R. Clusterin is an ATP-independent chaperone with very broad substrate specificity that stabilizes stressed proteins in a folding-competent state. Biochemistry 2000, 39, 15953-15960. [CrossRef]

326. Shepherd, C.E.; Affleck, A.J.; Bahar, A.Y.; Carew-Jones, F.; Halliday, G.M. Intracellular and secreted forms of clusterin are elevated early in Alzheimer's disease and associate with both Abeta and tau pathology. Neurobiol. Aging 2020, 89, 129-131. [CrossRef] [PubMed]

327. Zhou, Y.; Hayashi, I.; Wong, J.; Tugusheva, K.; Renger, J.J.; Zerbinatti, C. Intracellular clusterin interacts with brain isoforms of the bridging integrator 1 and with the microtubule-associated protein Tau in Alzheimer's disease. PLoS ONE 2014, 9, e103187. [CrossRef] [PubMed]

328. Schmid, F.X.; Mayr, L.M.; Mucke, M.; Schonbrunner, E.R. Prolyl isomerases: Role in protein folding. Adv. Protein Chem. 1993, 44, 25-66. [PubMed]

329. Morgan, A.A.; Rubenstein, E. Proline: The distribution, frequency, positioning, and common functional roles of proline and polyproline sequences in the human proteome. PLoS ONE 2013, 8, e53785. [CrossRef] 
330. Goode, B.L.; Denis, P.E.; Panda, D.; Radeke, M.J.; Miller, H.P.; Wilson, L.; Feinstein, S.C. Functional interactions between the proline-rich and repeat regions of tau enhance microtubule binding and assembly. Mol. Biol. Cell 1997, 8, 353-365. [CrossRef]

331. Bielska, A.A.; Zondlo, N.J. Hyperphosphorylation of tau induces local polyproline II helix. Biochemistry 2006, 45, 5527-5537. [CrossRef]

332. Koren, J.; Jinwal, U.K.; Davey, Z.; Kiray, J.; Arulselvam, K.; Dickey, C.A. Bending tau into shape: The emerging role of peptidylprolyl isomerases in tauopathies. Mol. Neurobiol. 2011, 44, 65-70. [CrossRef] [PubMed]

333. Chambraud, B.; Sardin, E.; Giustiniani, J.; Dounane, O.; Schumacher, M.; Goedert, M.; Baulieu, E.E. A role for FKBP52 in Tau protein function. Proc. Natl. Acad. Sci. USA 2010, 107, 2658-2663. [CrossRef]

334. Lu, P.-J.; Wulf, G.; Zhou, X.Z.; Davies, P.; Lu, K.P. The prolyl isomerase Pin1 restores the function of Alzheimer-associated phosphorylated tau protein. Nature 1999, 399, 784-788. [CrossRef]

335. Gruber, C.W.; Cemazar, M.; Heras, B.; Martin, J.L.; Craik, D.J. Protein disulfide isomerase: The structure of oxidative folding. Trends Biochem. Sci. 2006, 31, 455-464. [CrossRef]

336. Xu, L.R.; Liu, X.L.; Chen, J.; Liang, Y. Protein disulfide isomerase interacts with tau protein and inhibits its fibrillization. PLoS ONE 2013, 8, e76657. [CrossRef] [PubMed]

337. Wegmann, S.; Eftekharzadeh, B.; Tepper, K.; Zoltowska, K.M.; Bennett, R.E.; Dujardin, S.; Laskowski, P.R.; MacKenzie, D.; Kamath, T.; Commins, C.; et al. Tau protein liquid-liquid phase separation can initiate tau aggregation. EMBO J. 2018, 37 , e98049. [CrossRef] [PubMed]

338. Wang, K.; Liu, J.Q.; Zhong, T.; Liu, X.L.; Zeng, Y.; Qiao, X.; Xie, T.; Chen, Y.; Gao, Y.Y.; Tang, B.; et al. Phase Separation and Cytotoxicity of Tau are Modulated by Protein Disulfide Isomerase and S-nitrosylation of this Molecular Chaperone. J. Mol. Biol. 2020, 432, 2141-2163. [CrossRef] [PubMed]

339. Uehara, T.; Nakamura, T.; Yao, D.; Shi, Z.Q.; Gu, Z.; Ma, Y.; Masliah, E.; Nomura, Y.; Lipton, S.A. S-nitrosylated protein-disulphide isomerase links protein misfolding to neurodegeneration. Nature 2006, 441, 513-517. [CrossRef] [PubMed]

340. Honjo, Y.; Horibe, T.; Torisawa, A.; Ito, H.; Nakanishi, A.; Mori, H.; Komiya, T.; Takahashi, R.; Kawakami, K. Protein disulfide isomerase P5-immunopositive inclusions in patients with Alzheimer's disease. J. Alzheimers Dis. 2014, 38, 601-609. [CrossRef] [PubMed]

341. Blair, L.J.; Baker, J.D.; Sabbagh, J.J.; Dickey, C.A. The emerging role of peptidyl-prolyl isomerase chaperones in tau oligomerization, amyloid processing, and Alzheimer's disease. J. Neurochem. 2015, 133, 1-13. [CrossRef]

342. Peak, S.L.; Gracia, L.; Lora, G.; Jinwal, U.K. Hsp90-interacting Co-chaperones and their Family Proteins in Tau Regulation: Introducing a Novel Role for Cdc37L1. Neuroscience 2021, 453, 312-323. [CrossRef]

343. Amadoro, G.; Corsetti, V.; Atlante, A.; Florenzano, F.; Capsoni, S.; Bussani, R.; Mercanti, D.; Calissano, P. Interaction between $\mathrm{NH} 2$-tau fragment and $\mathrm{A} \beta$ in Alzheimer's disease mitochondria contributes to the synaptic deterioration. Neurobiol. Aging 2012, 33, 833.e1-833.e25. [CrossRef]

344. Elrod, J.W.; Molkentin, J.D. Physiologic functions of cyclophilin D and the mitochondrial permeability transition pore. Circ. J. 2013, 77, 1111-1122. [CrossRef] [PubMed]

345. Schinzel, A.C.; Takeuchi, O.; Huang, Z.; Fisher, J.K.; Zhou, Z.; Rubens, J.; Hetz, C.; Danial, N.N.; Moskowitz, M.A.; Korsmeyer, S.J. Cyclophilin D is a component of mitochondrial permeability transition and mediates neuronal cell death after focal cerebral ischemia. Proc. Natl. Acad. Sci. USA 2005, 102, 12005-12010. [CrossRef] [PubMed]

346. Baines, C.P.; Kaiser, R.A.; Purcell, N.H.; Blair, N.S.; Osinska, H.; Hambleton, M.A.; Brunskill, E.W.; Sayen, M.R.; Gottlieb, R.A.; Dorn, G.W. Loss of cyclophilin D reveals a critical role for mitochondrial permeability transition in cell death. Nature 2005, 434, 658-662. [CrossRef] [PubMed]

347. Guo, C.; Sun, L.; Chen, X.; Zhang, D. Oxidative stress, mitochondrial damage and neurodegenerative diseases. Neural Regen. Res. 2013, 8, 2003. [PubMed]

348. Berridge, M.J. Dysregulation of neural calcium signaling in Alzheimer disease, bipolar disorder and schizophrenia. Prion 2013, 7, 2-13. [CrossRef]

349. Abeti, R.; Abramov, A.Y. Mitochondrial Ca2+ in neurodegenerative disorders. Pharmacol. Res. 2015, 99, 377-381. [CrossRef]

350. Du, H.; Guo, L.; Fang, F.; Chen, D.; Sosunov, A.A.; McKhann, G.M.; Yan, Y.; Wang, C.; Zhang, H.; Molkentin, J.D. Cyclophilin D deficiency attenuates mitochondrial and neuronal perturbation and ameliorates learning and memory in Alzheimer's disease. Nat. Med. 2008, 14, 1097-1105. [CrossRef]

351. Du, H.; Guo, L.; Zhang, W.; Rydzewska, M.; Yan, S. Cyclophilin D deficiency improves mitochondrial function and learning/memory in aging Alzheimer disease mouse model. Neurobiol. Aging 2011, 32, 398-406. [CrossRef]

352. Jara, C.; Cerpa, W.; Tapia-Rojas, C.; Quintanilla, R.A. Tau deletion prevents cognitive impairment and mitochondrial dysfunction age-associated by a mechanism dependent on Cyclophilin-D (CypD). Front. Neurosci. 2020, 14, 1480.

353. Pérez, M.J.; Jara, C.; Quintanilla, R.A. Contribution of tau pathology to mitochondrial impairment in neurodegeneration. Front. Neurosci. 2018, 12, 441. [CrossRef]

354. Shimohama, S. Apoptosis in Alzheimer's disease-An update. Apoptosis 2000, 5, 9-16. [CrossRef]

355. Strasser, A.; O'Connor, L.; Dixit, V.M. Apoptosis signaling. Annu. Rev. Biochem. 2000, 69, 217-245. [CrossRef]

356. Chung, C.-W.; Song, Y.-H.; Kim, I.-K.; Yoon, W.-J.; Ryu, B.-R.; Jo, D.-G.; Woo, H.-N.; Kwon, Y.-K.; Kim, H.-H.; Gwag, B.-J. Proapoptotic effects of tau cleavage product generated by caspase-3. Neurobiol. Dis. 2001, 8, 162-172. [CrossRef] [PubMed] 
357. Cotman, C.W.; Poon, W.W.; Rissman, R.A.; Blurton-Jones, M. The role of caspase cleavage of tau in Alzheimer disease neuropathology. J. Neuropathol. Exp. Neurol. 2005, 64, 104-112. [CrossRef] [PubMed]

358. Zilka, N.; Kovacech, B.; Barath, P.; Kontsekova, E.; Novák, M. The Self-Perpetuating tau Truncation Circle; Portland Press Ltd.: London, UK, 2012.

359. Miao, E.A.; Rajan, J.V.; Aderem, A. Caspase-1-induced pyroptotic cell death. Immunol. Rev. 2011, 243, 206-214. [CrossRef]

360. Chu, J.; Lauretti, E.; Praticò, D. Caspase-3-dependent cleavage of Akt modulates tau phosphorylation via GSK3 $\beta$ kinase: Implications for Alzheimer's disease. Mol. Psychiatry 2017, 22, 1002-1008. [CrossRef]

361. Glushakova, O.Y.; Glushakov, A.O.; Borlongan, C.V.; Valadka, A.B.; Hayes, R.L.; Glushakov, A.V. Role of Caspase-3-Mediated Apoptosis in Chronic Caspase-3-Cleaved Tau Accumulation and Blood-Brain Barrier Damage in the Corpus Callosum after Traumatic Brain Injury in Rats. J. Neurotrauma 2018, 35, 157-173. [CrossRef]

362. Horowitz, P.M.; Patterson, K.R.; Guillozet-Bongaarts, A.L.; Reynolds, M.R.; Carroll, C.A.; Weintraub, S.T.; Bennett, D.A.; Cryns, V.L.; Berry, R.W.; Binder, L.I. Early N-terminal changes and caspase-6 cleavage of tau in Alzheimer's disease. J. Neurosci. 2004, 24, 7895-7902. [CrossRef]

363. Guo, H.; Albrecht, S.; Bourdeau, M.; Petzke, T.; Bergeron, C.; LeBlanc, A.C. Active caspase-6 and caspase-6-cleaved tau in neuropil threads, neuritic plaques, and neurofibrillary tangles of Alzheimer's disease. Am. J. Pathol. 2004, 165, 523-531. [CrossRef]

364. Zhao, H.; Zhao, W.; Lok, K.; Wang, Z.; Yin, M. A Synergic Role of Caspase-6 and Caspase-3 in Tau Truncation at D421 Induced by $\mathrm{H}_{2} \mathrm{O}_{2}$. Cell. Mol. Neurobiol. 2014, 34, 369-378. [CrossRef] [PubMed]

365. Albrecht, S.; Bogdanovic, N.; Ghetti, B.; Winblad, B.; LeBlanc, A.C. Caspase-6 activation in familial Alzheimer disease brains carrying amyloid precursor protein or presenilin I or presenilin II mutations. J. Neuropathol. Exp. Neurol. 2009, 68, 1282-1293. [CrossRef]

366. Wang, X.J.; Cao, Q.; Zhang, Y.; Su, X.D. Activation and regulation of caspase-6 and its role in neurodegenerative diseases. Annu. Rev. Pharm. Toxicol. 2015, 55, 553-572. [CrossRef]

367. Gervais, F.G.; Xu, D.; Robertson, G.S.; Vaillancourt, J.P.; Zhu, Y.; Huang, J.; LeBlanc, A.; Smith, D.; Rigby, M.; Shearman, M.S.; et al. Involvement of caspases in proteolytic cleavage of Alzheimer's amyloid-beta precursor protein and amyloidogenic A beta peptide formation. Cell 1999, 97, 395-406. [CrossRef]

368. Pellegrini, L.; Passer, B.J.; Tabaton, M.; Ganjei, J.K.; D'Adamio, L. Alternative, non-secretase processing of Alzheimer's betaamyloid precursor protein during apoptosis by caspase-6 and -8. J. Biol. Chem. 1999, 274, 21011-21016. [CrossRef]

369. Lu, D.C.; Rabizadeh, S.; Chandra, S.; Shayya, R.F.; Ellerby, L.M.; Ye, X.; Salvesen, G.S.; Koo, E.H.; Bredesen, D.E. A second cytotoxic proteolytic peptide derived from amyloid beta-protein precursor. Nat. Med. 2000, 6, 397-404. [CrossRef]

370. Park, S.A.; Shaked, G.M.; Bredesen, D.E.; Koo, E.H. Mechanism of cytotoxicity mediated by the C31 fragment of the amyloid precursor protein. Biochem. Biophys. Res. Commun. 2009, 388, 450-455. [CrossRef]

371. Gonçalves, A.V.; Margolis, S.R.; Quirino, G.F.; Mascarenhas, D.P.; Rauch, I.; Nichols, R.D.; Ansaldo, E.; Fontana, M.F.; Vance, R.E.; Zamboni, D.S. Gasdermin-D and Caspase-7 are the key Caspase-1/8 substrates downstream of the NAIP5/NLRC4 inflammasome required for restriction of Legionella pneumophila. PLoS Pathog. 2019, 15, e1007886. [CrossRef]

372. Ayers, K.L.; Mirshahi, U.L.; Wardeh, A.H.; Murray, M.F.; Hao, K.; Glicksberg, B.S.; Li, S.; Carey, D.J.; Chen, R. A loss of function variant in CASP7 protects against Alzheimer's disease in homozygous APOE epsilon4 allele carriers. BMC Genom. 2016, 17 (Suppl. 2), 445. [CrossRef]

373. Zhang, X.; Zhu, C.; Beecham, G.; Vardarajan, B.N.; Ma, Y.; Lancour, D.; Farrell, J.J.; Chung, J.; Alzheimer's Disease Sequencing, P.; Mayeux, R.; et al. A rare missense variant of CASP7 is associated with familial late-onset Alzheimer's disease. Alzheimers Dement 2019, 15, 441-452. [CrossRef]

374. Muzio, M.; Stockwell, B.R.; Stennicke, H.R.; Salvesen, G.S.; Dixit, V.M. An induced proximity model for caspase-8 activation. J. Biol. Chem. 1998, 273, 2926-2930. [CrossRef]

375. Stennicke, H.R.; Jurgensmeier, J.M.; Shin, H.; Deveraux, Q.; Wolf, B.B.; Yang, X.; Zhou, Q.; Ellerby, H.M.; Ellerby, L.M.; Bredesen, D.; et al. Pro-caspase-3 is a major physiologic target of caspase-8. J. Biol. Chem. 1998, 273, 27084-27090. [CrossRef]

376. Rohn, T.T.; Head, E.; Nesse, W.H.; Cotman, C.W.; Cribbs, D.H. Activation of caspase-8 in the Alzheimer's disease brain. Neurobiol. Dis. 2001, 8, 1006-1016. [CrossRef]

377. Rehker, J.; Rodhe, J.; Nesbitt, R.R.; Boyle, E.A.; Martin, B.K.; Lord, J.; Karaca, I.; Naj, A.; Jessen, F.; Helisalmi, S.; et al. Caspase-8, association with Alzheimer's Disease and functional analysis of rare variants. PLoS ONE 2017, 12, e0185777.

378. O'Brien, R.J.; Xu, D.; Petralia, R.S.; Steward, O.; Huganir, R.L.; Worley, P. Synaptic clustering of AMPA receptors by the extracellular immediate-early gene product Narp. Neuron 1999, 23, 309-323. [CrossRef]

379. Allen, N.J.; Bennett, M.L.; Foo, L.C.; Wang, G.X.; Chakraborty, C.; Smith, S.J.; Barres, B.A. Astrocyte glypicans 4 and 6 promote formation of excitatory synapses via GluA1 AMPA receptors. Nature 2012, 486, 410-414. [CrossRef]

380. Groc, L.; Gustafsson, B.; Hanse, E. AMPA signalling in nascent glutamatergic synapses: There and not there! Trends Neurosci. 2006, 29, 132-139. [CrossRef]

381. Farhy-Tselnicker, I.; van Casteren, A.C.; Lee, A.; Chang, V.T.; Aricescu, A.R.; Allen, N.J. Astrocyte-secreted glypican 4 regulates release of neuronal pentraxin 1 from axons to induce functional synapse formation. Neuron 2017, 96, 428-445.e13. [CrossRef] [PubMed]

382. DeGregorio-Rocasolano, N.; Gasull, T.; Trullas, R. Overexpression of neuronal pentraxin 1 is involved in neuronal death evoked by low K+ in cerebellar granule cells. J. Biol. Chem. 2001, 276, 796-803. [CrossRef] [PubMed] 
383. Enguita, M.; DeGregorio-Rocasolano, N.; Abad, A.; Trullas, R. Glycogen synthase kinase 3 activity mediates neuronal pentraxin 1 expression and cell death induced by potassium deprivation in cerebellar granule cells. Mol. Pharmacol. 2005, 67, 1237-1246. [CrossRef] [PubMed]

384. Abad, M.A.; Enguita, M.; De Gregorio-Rocasolano, N.; Ferrer, I.; Trullas, R. Neuronal pentraxin 1 contributes to the neuronal damage evoked by amyloid- $\beta$ and is overexpressed in dystrophic neurites in Alzheimer's brain. J. Neurosci. 2006, 26, 12735-12747. [CrossRef] [PubMed]

385. Martinez-Vicente, M.; Sovak, G.; Cuervo, A.M. Protein degradation and aging. Exp. Gerontol. 2005, 40, 622-633. [CrossRef] [PubMed]

386. Gafni, J.; Ellerby, L.M. Calpain activation in Huntington's disease. J. Neurosci. 2002, 22, 4842-4849. [CrossRef]

387. Gafni, J.; Hermel, E.; Young, J.E.; Wellington, C.L.; Hayden, M.R.; Ellerby, L.M. Inhibition of calpain cleavage of huntingtin reduces toxicity: Accumulation of calpain/caspase fragments in the nucleus. J. Biol. Chem. 2004, 279, 20211-20220. [CrossRef]

388. Anderson, J.P.; Walker, D.E.; Goldstein, J.M.; De Laat, R.; Banducci, K.; Caccavello, R.J.; Barbour, R.; Huang, J.; Kling, K.; Lee, M. Phosphorylation of Ser-129 is the dominant pathological modification of $\alpha$-synuclein in familial and sporadic Lewy body disease. J. Biol. Chem. 2006, 281, 29739-29752. [CrossRef]

389. Berke, S.J.S.; Schmied, F.A.F.; Brunt, E.R.; Ellerby, L.M.; Paulson, H.L. Caspase-mediated proteolysis of the polyglutamine disease protein ataxin-3. J. Neurochem. 2004, 89, 908-918. [CrossRef]

390. Goti, D.; Katzen, S.M.; Mez, J.; Kurtis, N.; Kiluk, J.; Ben-Haïem, L.; Jenkins, N.A.; Copeland, N.G.; Kakizuka, A.; Sharp, A.H. A mutant ataxin-3 putative-cleavage fragment in brains of Machado-Joseph disease patients and transgenic mice is cytotoxic above a critical concentration. J. Neurosci. 2004, 24, 10266-10279. [CrossRef]

391. Forloni, G.; Angeretti, N.; Chiesa, R.; Monzani, E.; Salmona, M.; Bugiani, O.; Tagliavini, F. Neurotoxicity of a prion protein fragment. Nature 1993, 362, 543-546. [CrossRef] [PubMed]

392. Soto, C. Unfolding the role of protein misfolding in neurodegenerative diseases. Nat. Rev. Neurosci. 2003, 4, 49-60. [CrossRef] [PubMed]

393. Novak, M.; Kabat, J.; Wischik, C.M. Molecular characterization of the minimal protease resistant tau unit of the Alzheimer's disease paired helical filament. EMBO J. 1993, 12, 365-370. [CrossRef] [PubMed]

394. Wischik, C.M.; Novak, M.; Edwards, P.C.; Klug, A.; Tichelaar, W.; Crowther, R.A. Structural characterization of the core of the paired helical filament of Alzheimer disease. Proc. Natl. Acad. Sci. USA 1988, 85, 4884-4888. [CrossRef] [PubMed]

395. Wischik, C.M.; Novak, M.; Thogersen, H.C.; Edwards, P.C.; Runswick, M.J.; Jakes, R.; Walker, J.E.; Milstein, C.; Roth, M.; Klug, A. Isolation of a fragment of tau derived from the core of the paired helical filament of Alzheimer disease. Proc. Natl. Acad. Sci. USA 1988, 85, 4506-4510. [CrossRef]

396. Quinn, J.P.; Corbett, N.J.; Kellett, K.A.; Hooper, N.M. Tau proteolysis in the pathogenesis of tauopathies: Neurotoxic fragments and novel biomarkers. J. Alzheimer's Dis. 2018, 63, 13-33. [CrossRef]

397. Zilka, N.; Filipcik, P.; Koson, P.; Fialova, L.; Skrabana, R.; Zilkova, M.; Rolkova, G.; Kontsekova, E.; Novak, M. Truncated tau from sporadic Alzheimer's disease suffices to drive neurofibrillary degeneration in vivo. FEBS Lett. 2006, 580, 3582-3588. [CrossRef]

398. Igaz, L.M.; Kwong, L.K.; Chen-Plotkin, A.; Winton, M.J.; Unger, T.L.; Xu, Y.; Neumann, M.; Trojanowski, J.Q.; Lee, V.M. Expression of TDP-43 C-terminal Fragments in Vitro Recapitulates Pathological Features of TDP-43 Proteinopathies. J. Biol. Chem. 2009, 284, 8516-8524. [CrossRef]

399. Filipcik, P.; Zilka, N.; Bugos, O.; Kucerak, J.; Koson, P.; Novak, P.; Novak, M. First transgenic rat model developing progressive cortical neurofibrillary tangles. Neurobiol. Aging 2012, 33, 1448-1456. [CrossRef]

400. Tennstaedt, A.; Popsel, S.; Truebestein, L.; Hauske, P.; Brockmann, A.; Schmidt, N.; Irle, I.; Sacca, B.; Niemeyer, C.M.; Brandt, R.; et al. Human high temperature requirement serine protease A1 (HTRA1) degrades tau protein aggregates. J. Biol. Chem. 2012, 287, 20931-20941. [CrossRef]

401. Glading, A.; Bodnar, R.; Reynolds, I.; Shiraha, H.; Satish, L.; Potter, D.; Blair, H.; Wells, A. Epidermal growth factor activates $\mathrm{m}$-calpain (calpain II), at least in part, by extracellular signal-regulated kinase-mediated phosphorylation. Mol. Cell. Biol. 2004, 24, 2499-2512. [CrossRef]

402. Yang, L.S.; Ksiezak-Reding, H. Calpain-induced proteolysis of normal human tau and tau associated with paired helical filaments. Eur. J. Biochem. 1995, 233, 9-17. [CrossRef]

403. Baudry, M.; Bi, X. Calpain-1 and Calpain-2: The Yin and Yang of Synaptic Plasticity and Neurodegeneration. Trends Neurosci 2016, 39, 235-245. [CrossRef] [PubMed]

404. Kurbatskaya, K.; Phillips, E.C.; Croft, C.L.; Dentoni, G.; Hughes, M.M.; Wade, M.A.; Al-Sarraj, S.; Troakes, C.; O’Neill, M.J.; PerezNievas, B.G.; et al. Upregulation of calpain activity precedes tau phosphorylation and loss of synaptic proteins in Alzheimer's disease brain. Acta Neuropathol. Commun. 2016, 4, 34. [CrossRef] [PubMed]

405. Park, S.Y.; Ferreira, A. The generation of a $17 \mathrm{kDa}$ neurotoxic fragment: An alternative mechanism by which tau mediates beta-amyloid-induced neurodegeneration. J. Neurosci. 2005, 25, 5365-5375. [CrossRef] [PubMed]

406. Garg, S.; Timm, T.; Mandelkow, E.M.; Mandelkow, E.; Wang, Y. Cleavage of Tau by calpain in Alzheimer's disease: The quest for the toxic $17 \mathrm{kD}$ fragment. Neurobiol. Aging 2011, 32, 1-14. [CrossRef] [PubMed]

407. Matsumoto, S.E.; Motoi, Y.; Ishiguro, K.; Tabira, T.; Kametani, F.; Hasegawa, M.; Hattori, N. The twenty-four KDa C-terminal tau fragment increases with aging in tauopathy mice: Implications of prion-like properties. Hum. Mol. Genet. 2015, 24, $6403-6416$. [CrossRef] 
408. Cicognola, C.; Satir, T.M.; Brinkmalm, G.; Matecko-Burmann, I.; Agholme, L.; Bergstrom, P.; Becker, B.; Zetterberg, H.; Blennow, K.; Hoglund, K. Tauopathy-Associated Tau Fragment Ending at Amino Acid 224 Is Generated by Calpain-2 Cleavage. J. Alzheimers Dis. 2020, 74, 1143-1156. [CrossRef]

409. Cicognola, C.; Brinkmalm, G.; Wahlgren, J.; Portelius, E.; Gobom, J.; Cullen, N.C.; Hansson, O.; Parnetti, L.; Constantinescu, R.; Wildsmith, K.; et al. Novel tau fragments in cerebrospinal fluid: Relation to tangle pathology and cognitive decline in Alzheimer's disease. Acta Neuropathol. 2019, 137, 279-296. [CrossRef]

410. Zhang, Z.; Song, M.; Liu, X.; Kang, S.S.; Kwon, I.S.; Duong, D.M.; Seyfried, N.T.; Hu, W.T.; Liu, Z.; Wang, J.Z.; et al. Cleavage of tau by asparagine endopeptidase mediates the neurofibrillary pathology in Alzheimer's disease. Nat. Med. 2014, 20, 1254-1262. [CrossRef]

411. Wang, Z.-H.; Liu, P.; Liu, X.; Manfredsson, F.P.; Sandoval, I.M.; Yu, S.P.; Wang, J.-Z.; Ye, K. Delta-secretase phosphorylation by SRPK2 enhances its enzymatic activity, provoking pathogenesis in Alzheimer's disease. Mol. Cell 2017, 67, 812-825.e5. [CrossRef] [PubMed]

412. Wang, P.; Joberty, G.; Buist, A.; Vanoosthuyse, A.; Stancu, I.C.; Vasconcelos, B.; Pierrot, N.; Faelth-Savitski, M.; Kienlen-Campard, P.; Octave, J.N.; et al. Tau interactome mapping based identification of Otub1 as Tau deubiquitinase involved in accumulation of pathological Tau forms in vitro and in vivo. Acta Neuropathol. 2017, 133, 731-749. [CrossRef]

413. Dall, E.; Brandstetter, H. Structure and function of legumain in health and disease. Biochimie 2016, 122, 126-150. [CrossRef]

414. Basurto-Islas, G.; Grundke-Iqbal, I.; Tung, Y.C.; Liu, F.; Iqbal, K. Activation of asparaginyl endopeptidase leads to Tau hyperphosphorylation in Alzheimer disease. J. Biol. Chem. 2013, 288, 17495-17507. [CrossRef]

415. Harrigan, J.A.; Jacq, X.; Martin, N.M.; Jackson, S.P. Deubiquitylating enzymes and drug discovery: Emerging opportunities. Nat. Rev. Drug Discov. 2018, 17, 57-78. [CrossRef]

416. Kontaxi, C.; Piccardo, P.; Gill, A.C. Lysine-Directed Post-translational Modifications of Tau Protein in Alzheimer's Disease and Related Tauopathies. Front. Mol. Biosci. 2017, 4, 56. [CrossRef]

417. Letronne, F.; Laumet, G.; Ayral, A.M.; Chapuis, J.; Demiautte, F.; Laga, M.; Vandenberghe, M.E.; Malmanche, N.; Leroux, F.; Eysert, F.; et al. ADAM30 Downregulates APP-Linked Defects Through Cathepsin D Activation in Alzheimer's Disease. EBioMedicine 2016, 9, 278-292. [CrossRef] [PubMed]

418. Khurana, V.; Elson-Schwab, I.; Fulga, T.A.; Sharp, K.A.; Loewen, C.A.; Mulkearns, E.; Tyynelä, J.; Scherzer, C.R.; Feany, M.B. Lysosomal dysfunction promotes cleavage and neurotoxicity of tau in vivo. PLoS Genet. 2010, 6, e1001026. [CrossRef] [PubMed]

419. Egberts, F.; Heinrich, M.; Jensen, J.M.; Winoto-Morbach, S.; Pfeiffer, S.; Wickel, M.; Schunck, M.; Steude, J.; Saftig, P.; Proksch, E.; et al. Cathepsin D is involved in the regulation of transglutaminase 1 and epidermal differentiation. J. Cell Sci. 2004, 117 Pt 11, 2295-2307. [CrossRef]

420. Banay-Schwartz, M.; Bracco, F.; DeGuzman, T.; Lajtha, A. Developmental changes in the breakdown of brain tubulin by cerebral cathepsin D. Neurochem. Res. 1983, 8, 51-61. [CrossRef] [PubMed]

421. Banay-Schwartz, M.; Dahl, D.; Hui, K.S.; Lajtha, A. The breakdown of the individual neurofilament proteins by cathepsin D. Neurochem. Res. 1987, 12, 361-367. [CrossRef]

422. Woessner, J.F., Jr.; Shamberger, R.J., Jr. Purification and properties of cathepsin D from bovine uterus. J. Biol. Chem. 1971, 246, 1951-1960. [CrossRef]

423. Wolf, M.; Clark-Lewis, I.; Buri, C.; Langen, H.; Lis, M.; Mazzucchelli, L. Cathepsin D specifically cleaves the chemokines macrophage inflammatory protein-1 alpha, macrophage inflammatory protein-1 beta, and SLC that are expressed in human breast cancer. Am. J. Pathol. 2003, 162, 1183-1190. [CrossRef]

424. Hiraiwa, M.; Martin, B.M.; Kishimoto, Y.; Conner, G.E.; Tsuji, S.; O’Brien, J.S. Lysosomal proteolysis of prosaposin, the precursor of saposins (sphingolipid activator proteins): Its mechanism and inhibition by ganglioside. Arch. Biochem. Biophys. 1997, 341, 17-24. [CrossRef] [PubMed]

425. Kenessey, A.; Nacharaju, P.; Ko, L.W.; Yen, S.H. Degradation of tau by lysosomal enzyme cathepsin D: Implication for Alzheimer neurofibrillary degeneration. J. Neurochem. 1997, 69, 2026-2038. [CrossRef] [PubMed]

426. Benuck, M.; Marks, N.; Hashim, G.A. Metabolic instability of myelin proteins. Breakdown of basic protein induced by brain cathepsin D. Eur. J. Biochem. 1975, 52, 615-621. [CrossRef]

427. Sadik, G.; Kaji, H.; Takeda, K.; Yamagata, F.; Kameoka, Y.; Hashimoto, K.; Miyanaga, K.; Shinoda, T. In vitro processing of amyloid precursor protein by cathepsin D. Int. J. Biochem. Cell Biol. 1999, 31, 1327-1337. [CrossRef]

428. Heinrich, M.; Neumeyer, J.; Jakob, M.; Hallas, C.; Tchikov, V.; Winoto-Morbach, S.; Wickel, M.; Schneider-Brachert, W.; Trauzold, A.; Hethke, A.; et al. Cathepsin D links TNF-induced acid sphingomyelinase to Bid-mediated caspase- 9 and -3 activation. Cell Death Differ 2004, 11, 550-563. [CrossRef]

429. Papassotiropoulos, A.; Bagli, M.; Kurz, A.; Kornhuber, J.; Forstl, H.; Maier, W.; Pauls, J.; Lautenschlager, N.; Heun, R. A genetic variation of cathepsin D is a major risk factor for Alzheimer's disease. Ann. Neurol. 2000, 47, 399-403. [CrossRef]

430. Poepsel, S.; Sprengel, A.; Sacca, B.; Kaschani, F.; Kaiser, M.; Gatsogiannis, C.; Raunser, S.; Clausen, T.; Ehrmann, M. Determinants of amyloid fibril degradation by the PDZ protease HTRA1. Nat. Chem. Biol. 2015, 11, 862-869. [CrossRef] [PubMed]

431. Arai, T.; Guo, J.P.; McGeer, P.L. Proteolysis of non-phosphorylated and phosphorylated tau by thrombin. J. Biol. Chem. 2005, 280, 5145-5153. [CrossRef] [PubMed]

432. Marshall, R.S.; Vierstra, R.D. Dynamic regulation of the $26 \mathrm{~S}$ proteasome: From synthesis to degradation. Front. Mol. Biosci. 2019, 6, 40. [CrossRef] [PubMed] 
433. Zhang, J.Y.; Liu, S.J.; Li, H.L.; Wang, J.Z. Microtubule-associated protein tau is a substrate of ATP/Mg(2+)-dependent proteasome protease system. J. Neural. Transm. 2005, 112, 547-555. [CrossRef]

434. Kanayama, H.O.; Tamura, T.; Ugai, S.; Kagawa, S.; Tanahashi, N.; Yoshimura, T.; Tanaka, K.; Ichihara, A. Demonstration that a human $26 \mathrm{~S}$ proteolytic complex consists of a proteasome and multiple associated protein components and hydrolyzes ATP and ubiquitin-ligated proteins by closely linked mechanisms. Eur. J. Biochem. 1992, 206, 567-578. [CrossRef]

435. Voges, D.; Zwickl, P.; Baumeister, W. The $26 \mathrm{~S}$ proteasome: A molecular machine designed for controlled proteolysis. Annu. Rev. Biochem. 1999, 68, 1015-1068. [CrossRef]

436. Bard, J.A.M.; Goodall, E.A.; Greene, E.R.; Jonsson, E.; Dong, K.C.; Martin, A. Structure and Function of the 26S Proteasome. Annu. Rev. Biochem. 2018, 87,697-724. [CrossRef]

437. Borodovsky, A.; Kessler, B.M.; Casagrande, R.; Overkleeft, H.S.; Wilkinson, K.D.; Ploegh, H.L. A novel active site-directed probe specific for deubiquitylating enzymes reveals proteasome association of USP14. EMBO J. 2001, 20, 5187-5196. [CrossRef] [PubMed]

438. Lee, B.-H.; Lu, Y.; Prado, M.A.; Shi, Y.; Tian, G.; Sun, S.; Elsasser, S.; Gygi, S.P.; King, R.W.; Finley, D. USP14 deubiquitinates proteasome-bound substrates that are ubiquitinated at multiple sites. Nature 2016, 532, 398-401. [CrossRef] [PubMed]

439. Keck, S.; Nitsch, R.; Grune, T.; Ullrich, O. Proteasome inhibition by paired helical filament-tau in brains of patients with Alzheimer's disease. J. Neurochem. 2003, 85, 115-122. [CrossRef] [PubMed]

440. Myeku, N.; Clelland, C.L.; Emrani, S.; Kukushkin, N.V.; Yu, W.H.; Goldberg, A.L.; Duff, K.E. Tau-driven 26S proteasome impairment and cognitive dysfunction can be prevented early in disease by activating cAMP-PKA signaling. Nat. Med. 2016, 22, 46-53. [CrossRef] [PubMed]

441. Thibaudeau, T.A.; Anderson, R.T.; Smith, D.M. A common mechanism of proteasome impairment by neurodegenerative disease-associated oligomers. Nat. Commun. 2018, 9, 1-14. [CrossRef]

442. Sengupta, S.; Horowitz, P.M.; Karsten, S.L.; Jackson, G.R.; Geschwind, D.H.; Fu, Y.; Berry, R.W.; Binder, L.I. Degradation of tau protein by puromycin-sensitive aminopeptidase in vitro. Biochemistry 2006, 45, 15111-15119. [CrossRef]

443. Karsten, S.L.; Sang, T.K.; Gehman, L.T.; Chatterjee, S.; Liu, J.; Lawless, G.M.; Sengupta, S.; Berry, R.W.; Pomakian, J.; Oh, H.S.; et al. A genomic screen for modifiers of tauopathy identifies puromycin-sensitive aminopeptidase as an inhibitor of tau-induced neurodegeneration. Neuron 2006, 51, 549-560. [CrossRef] [PubMed]

444. Yang, G.; Zhou, R.; Zhou, Q.; Guo, X.; Yan, C.; Ke, M.; Lei, J.; Shi, Y. Structural basis of Notch recognition by human gammasecretase. Nature 2019, 565, 192-197. [CrossRef]

445. Zhou, R.; Yang, G.; Guo, X.; Zhou, Q.; Lei, J.; Shi, Y. Recognition of the amyloid precursor protein by human gamma-secretase Science 2019, 363, eaaw0930. [CrossRef] [PubMed]

446. Zhang, S.; Cai, F.; Wu, Y.; Bozorgmehr, T.; Wang, Z.; Zhang, S.; Huang, D.; Guo, J.; Shen, L.; Rankin, C.; et al. A presenilin-1 mutation causes Alzheimer disease without affecting Notch signaling. Mol. Psychiatry 2020, 25, 603-613. [CrossRef] [PubMed]

447. Russo, C.; Schettini, G.; Saido, T.C.; Hulette, C.; Lippa, C.; Lannfelt, L.; Ghetti, B.; Gambetti, P.; Tabaton, M.; Teller, J.K. Presenilin-1 mutations in Alzheimer's disease. Nature 2000, 405, 531-532. [CrossRef] [PubMed]

448. Takashima, A.; Murayama, M.; Murayama, O.; Kohno, T.; Honda, T.; Yasutake, K.; Nihonmatsu, N.; Mercken, M.; Yamaguchi, H.; Sugihara, S.; et al. Presenilin 1 associates with glycogen synthase kinase-3beta and its substrate tau. Proc. Natl. Acad. Sci. USA 1998, 95, 9637-9641. [CrossRef] [PubMed]

449. Kelleher, R.J., 3rd; Shen, J. Presenilin-1 mutations and Alzheimer's disease. Proc. Natl. Acad. Sci. USA 2017, 114, 629-631. [CrossRef] [PubMed]

450. Gordon-Weeks, P.R.; Fournier, A.E. Neuronal cytoskeleton in synaptic plasticity and regeneration. J. Neurochem. 2014, 129, 206-212. [CrossRef] [PubMed]

451. Goldstein, A.Y.; Wang, X.; Schwarz, T.L. Axonal transport and the delivery of pre-synaptic components. Curr. Opin. Neurobiol. 2008, 18, 495-503. [CrossRef]

452. Witte, H.; Bradke, F. The role of the cytoskeleton during neuronal polarization. Curr. Opin. Neurobiol. 2008, 18, 479-487. [CrossRef]

453. Alonso, A.d.C.; Zaidi, T.; Novak, M.; Barra, H.S.; Grundke-Iqbal, I.; Iqbal, K. Interaction of tau isoforms with Alzheimer's disease abnormally hyperphosphorylated tau and in VitroPhosphorylation into the disease-like protein. J. Biol. Chem. 2001, 276, 37967-37973. [CrossRef] [PubMed]

454. Paonessa, F.; Evans, L.D.; Solanki, R.; Larrieu, D.; Wray, S.; Hardy, J.; Jackson, S.P.; Livesey, F.J. Microtubules deform the nuclear membrane and disrupt nucleocytoplasmic transport in tau-mediated frontotemporal dementia. Cell Rep. 2019, 26, 582-593.e5. [CrossRef] [PubMed]

455. Seiberlich, V.; Goldbaum, O.; Zhukareva, V.; Richter-Landsberg, C. The small molecule inhibitor PR-619 of deubiquitinating enzymes affects the microtubule network and causes protein aggregate formation in neural cells: Implications for neurodegenerative diseases. Biochim. Biophys. Acta Mol. Cell Res. 2012, 1823, 2057-2068. [CrossRef]

456. Souter, S.; Lee, G. Microtubule-associated protein tau in human prostate cancer cells: Isoforms, phosphorylation, and interactions. J. Cell. Biochem. 2009, 108, 555-564. [CrossRef]

457. Lai, R.Y.; Harrington, C.R.; Wischik, C.M. Absence of a role for phosphorylation in the tau pathology of Alzheimer's disease. Biomolecules 2016, 6, 19. [CrossRef] 
458. Alonso, A.d.C.; Grundke-Iqbal, I.; Barra, H.S.; Iqbal, K. Abnormal phosphorylation of tau and the mechanism of Alzheimer neurofibrillary degeneration: Sequestration of microtubule-associated proteins 1 and 2 and the disassembly of microtubules by the abnormal tau. Proc. Natl. Acad. Sci. USA 1997, 94, 298-303. [CrossRef]

459. Harada, A.; Teng, J.; Takei, Y.; Oguchi, K.; Hirokawa, N. MAP2 is required for dendrite elongation, PKA anchoring in dendrites, and proper PKA signal transduction. J. Cell Biol. 2002, 158, 541-549. [CrossRef]

460. Kim, Y.; Jang, Y.N.; Kim, J.Y.; Kim, N.; Noh, S.; Kim, H.; Queenan, B.N.; Bellmore, R.; Mun, J.Y.; Park, H. Microtubule-associated protein 2 mediates induction of long-term potentiation in hippocampal neurons. FASEB J. 2020, 34, 6965-6983. [CrossRef] [PubMed]

461. Gumy, L.F.; Katrukha, E.A.; Grigoriev, I.; Jaarsma, D.; Kapitein, L.C.; Akhmanova, A.; Hoogenraad, C.C. MAP2 Defines a Pre-axonal Filtering Zone to Regulate KIF1- versus KIF5-Dependent Cargo Transport in Sensory Neurons. Neuron 2017, 94, 347-362.e7. [CrossRef] [PubMed]

462. Brouhard, G.J.; Rice, L.M. Microtubule dynamics: An interplay of biochemistry and mechanics. Nat. Rev. Mol. Cell Biol. 2018, 19, 451-463. [CrossRef] [PubMed]

463. Weisenberg, R.C.; Deery, W.J.; Dickinson, P.J. Tubulin-nucleotide interactions during the polymerization and depolymerization of microtubules. Biochemistry 1976, 15, 4248-4254. [CrossRef]

464. Panda, D.; Goode, B.L.; Feinstein, S.C.; Wilson, L. Kinetic stabilization of microtubule dynamics at steady state by tau and microtubule-binding domains of tau. Biochemistry 1995, 34, 11117-11127. [CrossRef] [PubMed]

465. Drechsel, D.N.; Hyman, A.; Cobb, M.H.; Kirschner, M. Modulation of the dynamic instability of tubulin assembly by the microtubule-associated protein tau. Mol. Biol. Cell 1992, 3, 1141-1154. [CrossRef]

466. Hayashi, I.; Wilde, A.; Mal, T.K.; Ikura, M. Structural basis for the activation of microtubule assembly by the EB1 and p150Glued complex. Mol. Cell 2005, 19, 449-460. [CrossRef]

467. Go, C.D.; Knight, J.D.; Rajasekharan, A.; Rathod, B.; Hesketh, G.G.; Abe, K.T.; Youn, J.-Y.; Samavarchi-Tehrani, P.; Zhang, H.; Zhu, L.Y. A proximity-dependent biotinylation map of a human cell: An interactive web resource. bioRxiv 2021. [CrossRef]

468. Askham, J.M.; Vaughan, K.T.; Goodson, H.V.; Morrison, E.E. Evidence that an interaction between EB1 and p150Glued is required for the formation and maintenance of a radial microtubule array anchored at the centrosome. Mol. Biol. Cell 2002, 13, 3627-3645 [CrossRef]

469. Yang, C.; Wu, J.; De Heus, C.; Grigoriev, I.; Liv, N.; Yao, Y.; Smal, I.; Meijering, E.; Klumperman, J.; Qi, R.Z. EB1 and EB3 regulate microtubule minus end organization and Golgi morphology. J. Cell Biol. 2017, 216, 3179-3198. [CrossRef] [PubMed]

470. Ramirez-Rios, S.; Denarier, E.; Prezel, E.; Vinit, A.; Stoppin-Mellet, V.; Devred, F.; Barbier, P.; Peyrot, V.; Sayas, C.L.; Avila, J. Tau antagonizes end-binding protein tracking at microtubule ends through a phosphorylation-dependent mechanism. Mol. Biol. Cell 2016, 27, 2924-2934. [CrossRef] [PubMed]

471. Sayas, C.L.; Medina, M.; Cuadros, R.; Ollá, I.; García, E.; Pérez, M.; Ferrer, I.; Hernández, F.; Avila, J. Role of tau N-terminal motif in the secretion of human tau by End Binding proteins. PLOS ONE 2019, 14, e0210864. [CrossRef]

472. Malki, I.; Cantrelle, F.X.; Sottejeau, Y.; Lippens, G.; Lambert, J.C.; Landrieu, I. Regulation of the interaction between the neuronal BIN 1 isoform 1 and Tau proteins-role of the SH 3 domain. FEBS J. 2017, 284, 3218-3229. [CrossRef]

473. Chapuis, J.; Hansmannel, F.; Gistelinck, M.; Mounier, A.; Van Cauwenberghe, C.; Kolen, K.; Geller, F.; Sottejeau, Y.; Harold, D.; Dourlen, P. Increased expression of BIN1 mediates Alzheimer genetic risk by modulating tau pathology. Mol. Psychiatry 2013, 18, 1225-1234. [CrossRef]

474. Wu, T.; Shi, Z.; Baumgart, T. Mutations in BIN1 associated with centronuclear myopathy disrupt membrane remodeling by affecting protein density and oligomerization. PLoS ONE 2014, 9, e93060. [CrossRef]

475. Wechsler-Reya, R.; Sakamuro, D.; Zhang, J.; Duhadaway, J.; Prendergast, G.C. Structural analysis of the human BIN1 gene. Evidence for tissue-specific transcriptional regulation and alternate RNA splicing. J. Biol. Chem. 1997, 272, 31453-31458. [CrossRef]

476. Seshadri, S.; Fitzpatrick, A.L.; Ikram, M.A.; DeStefano, A.L.; Gudnason, V.; Boada, M.; Bis, J.C.; Smith, A.V.; Carassquillo, M.M.; Lambert, J.C.; et al. Genome-wide analysis of genetic loci associated with Alzheimer disease. JAMA 2010, 303, $1832-1840$. [CrossRef] [PubMed]

477. Kingwell, K. Alzheimer disease: BIN1 variant increases risk of Alzheimer disease through tau. Nat. Rev. Neurol. 2013, 9, 184. [CrossRef] [PubMed]

478. Dharmalingam, E.; Haeckel, A.; Pinyol, R.; Schwintzer, L.; Koch, D.; Kessels, M.M.; Qualmann, B. F-BAR proteins of the syndapin family shape the plasma membrane and are crucial for neuromorphogenesis. J. Neurosci. 2009, 29, 13315-13327. [CrossRef]

479. Wang, Q.; Navarro, M.V.; Peng, G.; Molinelli, E.; Goh, S.L.; Judson, B.L.; Rajashankar, K.R.; Sondermann, H. Molecular mechanism of membrane constriction and tubulation mediated by the F-BAR protein Pacsin/Syndapin. Proc. Natl. Acad. Sci. USA 2009, 106, 12700-12705. [CrossRef]

480. Kessels, M.M.; Qualmann, B. Syndapins integrate N-WASP in receptor-mediated endocytosis. EMBO J. 2002, $21,6083-6094$. [CrossRef]

481. Plomann, M.; Lange, R.; Vopper, G.; Cremer, H.; Heinlein, U.A.; Scheff, S.; Baldwin, S.A.; Leitges, M.; Cramer, M.; Paulsson, M.; et al. PACSIN, a brain protein that is upregulated upon differentiation into neuronal cells. Eur. J. Biochem. 1998, 256, 201-211. [CrossRef] 
482. Pérez-Otaño, I.; Luján, R.; Tavalin, S.J.; Plomann, M.; Modregger, J.; Liu, X.-B.; Jones, E.G.; Heinemann, S.F.; Lo, D.C.; Ehlers, M.D. Endocytosis and synaptic removal of NR3A-containing NMDA receptors by PACSIN1/syndapin1. Nat. Neurosci. 2006, 9, 611-621. [CrossRef]

483. Carmignoto, G.; Vicini, S. Activity-dependent decrease in NMDA receptor responses during development of the visual cortex. Science 1992, 258, 1007-1011. [CrossRef] [PubMed]

484. Hestrin, S. Developmental regulation of NMDA receptor-mediated synaptic currents at a central synapse. Nature 1992, 357, 686-689. [CrossRef] [PubMed]

485. Sheng, M.; Cummings, J.; Roldan, L.A.; Jan, Y.N.; Jan, L.Y. Changing subunit composition of heteromeric NMDA receptors during development of rat cortex. Nature 1994, 368, 144-147. [CrossRef] [PubMed]

486. Yamagishi, A.; Masuda, M.; Ohki, T.; Onishi, H.; Mochizuki, N. A novel actin bundling/filopodium-forming domain conserved in insulin receptor tyrosine kinase substrate p53 and missing in metastasis protein. J. Biol. Chem. 2004, 279, 14929-14936. [CrossRef]

487. Scita, G.; Confalonieri, S.; Lappalainen, P.; Suetsugu, S. IRSp53: Crossing the road of membrane and actin dynamics in the formation of membrane protrusions. Trends Cell Biol. 2008, 18, 52-60. [CrossRef] [PubMed]

488. Kang, J.; Park, H.; Kim, E. IRSp53/BAIAP2 in dendritic spine development, NMDA receptor regulation, and psychiatric disorders. Neuropharmacology 2016, 100, 27-39. [CrossRef]

489. Disanza, A.; Mantoani, S.; Hertzog, M.; Gerboth, S.; Frittoli, E.; Steffen, A.; Berhoerster, K.; Kreienkamp, H.-J.; Milanesi, F.; Di Fiore, P.P. Regulation of cell shape by Cdc42 is mediated by the synergic actin-bundling activity of the Eps8-IRSp53 complex. Nat. Cell Biol. 2006, 8, 1337-1347. [CrossRef]

490. Okamura-Oho, Y.; Miyashita, T.; Yamada, M. Distinctive tissue distribution and phosphorylation of IRSp53 isoforms. Biochem. Biophys. Res. Commun. 2001, 289, 957-960. [CrossRef]

491. Fujiwara, T.; Mammoto, A.; Kim, Y.; Takai, Y. Rho small G-protein-dependent binding of mDia to an Src homology 3 domaincontaining IRSp53/BAIAP2. Biochem. Biophys. Res. Commun. 2000, 271, 626-629. [CrossRef]

492. Choi, J.; Ko, J.; Racz, B.; Burette, A.; Lee, J.-R.; Kim, S.; Na, M.; Lee, H.W.; Kim, K.; Weinberg, R.J. Regulation of dendritic spine morphogenesis by insulin receptor substrate 53, a downstream effector of Rac1 and Cdc42 small GTPases. J. Neurosci. 2005, 25, 869-879. [CrossRef]

493. Fromer, M.; Pocklington, A.J.; Kavanagh, D.H.; Williams, H.J.; Dwyer, S.; Gormley, P.; Georgieva, L.; Rees, E.; Palta, P.; Ruderfer, D.M. De novo mutations in schizophrenia implicate synaptic networks. Nature 2014, 506, 179-184. [CrossRef] [PubMed]

494. Purcell, S.M.; Moran, J.L.; Fromer, M.; Ruderfer, D.; Solovieff, N.; Roussos, P.; O'dushlaine, C.; Chambert, K.; Bergen, S.E.; Kähler, A. A polygenic burden of rare disruptive mutations in schizophrenia. Nature 2014, 506, 185-190. [CrossRef] [PubMed]

495. Levy, D.; Ronemus, M.; Yamrom, B.; Lee, Y.-h.; Leotta, A.; Kendall, J.; Marks, S.; Lakshmi, B.; Pai, D.; Ye, K. Rare de novo and transmitted copy-number variation in autistic spectrum disorders. Neuron 2011, 70, 886-897. [CrossRef]

496. Toma, C.; Hervás, A.; Balmaña, N.; Vilella, E.; Aguilera, F.; Cuscó, I.; del Campo, M.; Caballero, R.; De Diego-Otero, Y.; Ribasés, M. Association study of six candidate genes asymmetrically expressed in the two cerebral hemispheres suggests the involvement of BAIAP2 in autism. J. Psychiatr. Res. 2011, 45, 280-282. [CrossRef]

497. Liu, L.; Sun, L.; Li, Z.-H.; Li, H.-M.; Wei, L.-P.; Wang, Y.-F.; Qian, Q.-J. BAIAP2 exhibits association to childhood ADHD especially predominantly inattentive subtype in Chinese Han subjects. Behav. Brain Funct. 2013, 9, 1-9. [CrossRef]

498. Herrmann, L.; Wiegmann, C.; Arsalan-Werner, A.; Hilbrich, I.; Jager, C.; Flach, K.; Suttkus, A.; Lachmann, I.; Arendt, T.; Holzer, M. Hook proteins: Association with Alzheimer pathology and regulatory role of hook3 in amyloid beta generation. PLoS ONE 2015, 10, e0119423. [CrossRef]

499. Goitre, L.; Trapani, E.; Trabalzini, L.; Retta, S.F. The Ras superfamily of small GTPases: The unlocked secrets. Ras Signal. 2014, $1120,1-18$.

500. Carazo-Salas, R.E.; Guarguaglini, G.; Gruss, O.J.; Segref, A.; Karsenti, E.; Mattaj, I.W. Generation of GTP-bound Ran by RCC1 is required for chromatin-induced mitotic spindle formation. Nature 1999, 400, 178-181. [CrossRef]

501. Bao, X.; Liu, H.; Liu, X.; Ruan, K.; Zhang, Y.; Zhang, Z.; Hu, Q.; Liu, Y.; Akram, S.; Zhang, J. Mitosis-specific acetylation tunes Ran effector binding for chromosome segregation. J. Mol. Cell Biol. 2018, 10, 18-32. [CrossRef]

502. Melchior, F.; Paschal, B.; Evans, J.; Gerace, L. Inhibition of nuclear protein import by nonhydrolyzable analogues of GTP and identification of the small GTPase Ran/TC4 as an essential transport factor. J. Cell Biol. 1993, 123, 1649-1659. [CrossRef] [PubMed]

503. Görlich, D.; Pante, N.; Kutay, U.; Aebi, U.; Bischoff, F. Identification of different roles for RanGDP and RanGTP in nuclear protein import. EMBO J. 1996, 15, 5584-5594. [CrossRef]

504. Rudack, T.; Jenrich, S.; Brucker, S.; Vetter, I.R.; Gerwert, K.; Kötting, C. Catalysis of GTP hydrolysis by small GTPases at atomic detail by integration of X-ray crystallography, experimental, and theoretical IR spectroscopy. J. Biol. Chem. 2015, 290, 24079-24090. [CrossRef]

505. Fleming, L.M.; Weisgraber, K.H.; Strittmatter, W.J.; Troncoso, J.C.; Johnson, G.V. Differential binding of apolipoprotein E isoforms to tau and other cytoskeletal proteins. Exp. Neurol. 1996, 138, 252-260. [CrossRef]

506. Yu, Y.; Kuang, Y.L.; Lei, D.; Zhai, X.; Zhang, M.; Krauss, R.M.; Ren, G. Polyhedral 3D structure of human plasma very low density lipoproteins by individual particle cryo-electron tomography1. J. Lipid Res. 2016, 57, 1879-1888. [CrossRef]

507. Dawson, P.A.; Rudel, L.L. Intestinal cholesterol absorption. Curr Opin Lipidol 1999, 10, 315-320. [CrossRef]

508. Otvos, J.D. Measurement of lipoprotein subclass profiles by nuclear magnetic resonance spectroscopy. Clin. Lab. 2002, 48, 171-180. 
509. Rall, S.C., Jr.; Weisgraber, K.H.; Mahley, R.W. Human apolipoprotein E. The complete amino acid sequence. J. Biol. Chem. 1982, 257, 4171-4178. [CrossRef]

510. Heinsinger, N.M.; Gachechiladze, M.A.; Rebeck, G.W. Apolipoprotein E Genotype Affects Size of ApoE Complexes in Cerebrospinal Fluid. J. Neuropathol. Exp. Neurol. 2016, 75, 918-924. [CrossRef]

511. Roses, A.D.; Saunders, A.M. APOE is a major susceptibility gene for Alzheimer's disease. Curr. Opin. Biotechnol. $1994,5,663-667$. [CrossRef]

512. Strittmatter, W.J.; Saunders, A.M.; Goedert, M.; Weisgraber, K.H.; Dong, L.M.; Jakes, R.; Huang, D.Y.; Pericak-Vance, M.; Schmechel, D.; Roses, A.D. Isoform-specific interactions of apolipoprotein E with microtubule-associated protein tau: Implications for Alzheimer disease. Proc. Natl. Acad. Sci. USA 1994, 91, 11183-11186. [CrossRef]

513. Bullido, M.J.; Aldudo, J.; Frank, A.; Coria, F.; Avila, J.; Valdivieso, F. A polymorphism in the tau gene associated with risk for Alzheimer's disease. Neurosci. Lett. 2000, 278, 49-52. [CrossRef]

514. Yu, L.; Boyle, P.A.; Leurgans, S.; Schneider, J.A.; Bennett, D.A. Disentangling the effects of age and APOE on neuropathology and late life cognitive decline. Neurobiol. Aging 2014, 35, 819-826. [CrossRef] [PubMed]

515. Dhaenens, C.-M.; Van Brussel, E.; Schraen-Maschke, S.; Pasquier, F.; Delacourte, A.; Sablonnière, B. Association study of three polymorphisms of kinesin light-chain 1 gene with Alzheimer's disease. Neurosci. Lett. 2004, 368, 290-292. [CrossRef] [PubMed]

516. Rahman, A.; Friedman, D.S.; Goldstein, L.S. Two kinesin light chain genes in mice: Identification and characterization of the encoded proteins. J. Biol. Chem. 1998, 273, 15395-15403. [CrossRef]

517. Konecna, A.; Frischknecht, R.; Kinter, J.; Ludwig, A.; Steuble, M.; Meskenaite, V.; Indermühle, M.; Engel, M.; Cen, C.; Mateos, J.-M. Calsyntenin-1 docks vesicular cargo to kinesin-1. Mol. Biol. Cell 2006, 17, 3651-3663. [CrossRef] [PubMed]

518. Araki, Y.; Kawano, T.; Taru, H.; Saito, Y.; Wada, S.; Miyamoto, K.; Kobayashi, H.; Ishikawa, H.O.; Ohsugi, Y.; Yamamoto, T. The novel cargo Alcadein induces vesicle association of kinesin-1 motor components and activates axonal transport. EMBO J. 2007, 26, 1475-1486. [CrossRef] [PubMed]

519. Vagnoni, A.; Perkinton, M.S.; Gray, E.H.; Francis, P.T.; Noble, W.; Miller, C.C. Calsyntenin-1 mediates axonal transport of the amyloid precursor protein and regulates A $\beta$ production. Hum. Mol. Genet. 2012, 21, 2845-2854. [CrossRef]

520. Vagnoni, A.; Rodriguez, L.; Manser, C.; De Vos, K.J.; Miller, C.C. Phosphorylation of kinesin light chain 1 at serine 460 modulates binding and trafficking of calsyntenin-1. J. Cell Sci. 2011, 124, 1032-1042. [CrossRef]

521. Mórotz, G.M.; Glennon, E.B.; Greig, J.; Lau, D.H.; Bhembre, N.; Mattedi, F.; Muschalik, N.; Noble, W.; Vagnoni, A.; Miller, C.C. Kinesin light chain-1 serine-460 phosphorylation is altered in Alzheimer's disease and regulates axonal transport and processing of the amyloid precursor protein. Acta Neuropathol. Commun. 2019, 7, 1-13. [CrossRef]

522. Morel, M.; Héraud, C.; Nicaise, C.; Suain, V.; Brion, J.-P. Levels of kinesin light chain and dynein intermediate chain are reduced in the frontal cortex in Alzheimer's disease: Implications for axoplasmic transport. Acta Neuropathol. 2012, 123, 71-84. [CrossRef]

523. Falzone, T.L.; Gunawardena, S.; McCleary, D.; Reis, G.F.; Goldstein, L.S. Kinesin-1 transport reductions enhance human tau hyperphosphorylation, aggregation and neurodegeneration in animal models of tauopathies. Hum. Mol. Genet. 2010, 19, 4399-4408. [CrossRef] [PubMed]

524. Schroer, T.A. Dynactin. Annu. Rev. Cell Dev. Biol. 2004, 20, 759-779. [CrossRef] [PubMed]

525. Ayloo, S.; Lazarus, J.E.; Dodda, A.; Tokito, M.; Ostap, E.M.; Holzbaur, E.L. Dynactin functions as both a dynamic tether and brake during dynein-driven motility. Nat. Commun. 2014, 5, 1-11. [CrossRef] [PubMed]

526. Lill, R.; Nargang, F.E.; Neupert, W. Biogenesis of mitochondrial proteins. Curr. Opin. Cell Biol. 1996, 8, 505-512. [CrossRef]

527. Chai, Y.L.; Xing, H.; Chong, J.R.; Francis, P.T.; Ballard, C.G.; Chen, C.P.; Lai, M.K. Mitochondrial translocase of the outer membrane alterations may underlie dysfunctional oxidative phosphorylation in Alzheimer's disease. J. Alzheimer's Dis. 2018, 61, 793-801. [CrossRef]

528. Neupert, W.; Herrmann, J.M. Translocation of proteins into mitochondria. Annu. Rev. Biochem. 2007, 76, 723-749. [CrossRef]

529. Petersen, C.A.H.; Alikhani, N.; Behbahani, H.; Wiehager, B.; Pavlov, P.F.; Alafuzoff, I.; Leinonen, V.; Ito, A.; Winblad, B.; Glaser, E. The amyloid $\beta$-peptide is imported into mitochondria via the TOM import machinery and localized to mitochondrial cristae. Proc. Natl. Acad. Sci. USA 2008, 105, 13145-13150. [CrossRef]

530. Gawaz, M.; Douglas, M.; Klingenberg, M. Structure-function studies of adenine nucleotide transport in mitochondria. II. Biochemical analysis of distinct AAC1 and AAC2 proteins in yeast. J. Biol. Chem. 1990, 265, 14202-14208. [CrossRef]

531. Krüger, J.; Hinttala, R.; Majamaa, K.; Remes, A.M. Mitochondrial DNA haplogroups in early-onset Alzheimer's disease and frontotemporal lobar degeneration. Mol. Neurodegener. 2010, 5, 1-6. [CrossRef]

532. Copeland, W.C. Inherited mitochondrial diseases of DNA replication. Annu. Rev. Med. 2008, 59, 131-146. [CrossRef]

533. Sasaki, K.; Shimura, H.; Itaya, M.; Tanaka, R.; Mori, H.; Mizuno, Y.; Kosik, K.S.; Tanaka, S.; Hattori, N. Excitatory amino acid transporter 2 associates with phosphorylated tau and is localized in neurofibrillary tangles of tauopathic brains. FEBS Lett. 2009, 583, 2194-2200. [CrossRef]

534. Benussi, L.; Ghidoni, R.; Paterlini, A.; Nicosia, F.; Alberici, A.C.; Signorini, S.; Barbiero, L.; Binetti, G. Interaction between tau and alpha-synuclein proteins is impaired in the presence of P301L tau mutation. Exp. Cell Res. 2005, 308, 78-84. [CrossRef]

535. Cheng, F.; Vivacqua, G.; Yu, S. The role of alpha-synuclein in neurotransmission and synaptic plasticity. J. Chem. Neuroanat. 2011, 42, 242-248. [CrossRef] 
536. Pranke, I.M.; Morello, V.; Bigay, J.; Gibson, K.; Verbavatz, J.-M.; Antonny, B.; Jackson, C.L. $\alpha$-Synuclein and ALPS motifs are membrane curvature sensors whose contrasting chemistry mediates selective vesicle binding. J. Cell Biol. 2011, 194, 89-103. [CrossRef]

537. Jin, H.; Kanthasamy, A.; Ghosh, A.; Yang, Y.; Anantharam, V.; Kanthasamy, A.G. $\alpha$-Synuclein negatively regulates protein kinase $\mathrm{C} \delta$ expression to suppress apoptosis in dopaminergic neurons by reducing p300 histone acetyltransferase activity. J. Neurosci. 2011, 31, 2035-2051. [CrossRef]

538. Clayton, D.F.; George, J.M. Synucleins in synaptic plasticity and neurodegenerative disorders. J. Neurosci. Res. 1999, 58, 120-129. [CrossRef]

539. Burré, J.; Sharma, M.; Tsetsenis, T.; Buchman, V.; Etherton, M.R.; Südhof, T.C. $\alpha$-Synuclein promotes SNARE-complex assembly in vivo and in vitro. Science 2010, 329, 1663-1667. [CrossRef] [PubMed]

540. Hamilton, R.L. Lewy bodies in Alzheimer's disease: A neuropathological review of 145 cases using $\alpha$-synuclein immunohistochemistry. Brain Pathol. 2000, 10, 378-384. [CrossRef] [PubMed]

541. Arai, Y.; Yamazaki, M.; Mori, O.; Muramatsu, H.; Asano, G.; Katayama, Y. $\alpha$-Synuclein-positive structures in cases with sporadic Alzheimer's disease: Morphology and its relationship to tau aggregation. Brain Res. 2001, 888, 287-296. [CrossRef]

542. Giasson, B.I.; Forman, M.S.; Higuchi, M.; Golbe, L.I.; Graves, C.L.; Kotzbauer, P.T.; Trojanowski, J.Q.; Lee, V.M.-Y. Initiation and synergistic fibrillization of tau and alpha-synuclein. Science 2003, 300, 636-640. [CrossRef]

543. Oikawa, T.; Nonaka, T.; Terada, M.; Tamaoka, A.; Hisanaga, S.-i.; Hasegawa, M. $\alpha$-Synuclein fibrils exhibit gain of toxic function, promoting tau aggregation and inhibiting microtubule assembly. J. Biol. Chem. 2016, 291, 15046-15056. [CrossRef] [PubMed]

544. Duka, T.; Duka, V.; Joyce, J.N.; Sidhu, A. $\alpha$-Synuclein contributes to GSK-3 $\beta$-catalyzed Tau phosphorylation in Parkinson's disease models. FASEB J. 2009, 23, 2820-2830. [CrossRef] [PubMed]

545. Doetsch, F.; Caille, I.; Lim, D.A.; Garcia-Verdugo, J.M.; Alvarez-Buylla, A. Subventricular zone astrocytes are neural stem cells in the adult mammalian brain. Cell 1999, 97, 703-716. [CrossRef]

546. Seward, M.E.; Swanson, E.; Norambuena, A.; Reimann, A.; Cochran, J.N.; Li, R.; Roberson, E.D.; Bloom, G.S. Amyloid- $\beta$ signals through tau to drive ectopic neuronal cell cycle re-entry in Alzheimer's disease. J. Cell Sci. 2013, 126, 1278-1286. [CrossRef]

547. Frost, B.; Hemberg, M.; Lewis, J.; Feany, M.B. Tau promotes neurodegeneration through global chromatin relaxation. Nat. Neurosci. 2014, 17, 357-366. [CrossRef] [PubMed]

548. Hernández-Ortega, K.; Garcia-Esparcia, P.; Gil, L.; Lucas, J.J.; Ferrer, I. Altered machinery of protein synthesis in Alzheimer's: From the nucleolus to the ribosome. Brain Pathol. 2016, 26, 593-605. [CrossRef]

549. Barbato, C.; Corbi, N.; Canu, N.; Fanciulli, M.; Serafino, A.; Ciotti, M.; Libri, V.; Bruno, T.; Amadoro, G.; De Angelis, R.; et al $\mathrm{Rb}$ binding protein Che-1 interacts with Tau in cerebellar granule neurons. Modulation during neuronal apoptosis. Mol. Cell Neurosci 2003, 24, 1038-1050. [CrossRef] [PubMed]

550. Ueberham, U.; Rohn, S.; Ueberham, E.; Wodischeck, S.; Hilbrich, I.; Holzer, M.; Bruckner, M.K.; Gruschka, H.; Arendt, T. Pin1 promotes degradation of Smad proteins and their interaction with phosphorylated tau in Alzheimer's disease. Neuropathol. Appl. Neurobiol. 2014, 40, 815-832. [CrossRef]

551. Bruno, T.; De Angelis, R.; De Nicola, F.; Barbato, C.; Di Padova, M.; Corbi, N.; Libri, V.; Benassi, B.; Mattei, E.; Chersi, A.; et al. Che-1 affects cell growth by interfering with the recruitment of HDAC1 by Rb. Cancer Cell 2002, 2, 387-399. [CrossRef]

552. Wrighton, K.H.; Lin, X.; Feng, X.H. Phospho-control of TGF-beta superfamily signaling. Cell Res. 2009, 19, 8-20. [CrossRef]

553. Zheng, J.Y.; Sun, J.; Ji, C.M.; Shen, L.; Chen, Z.J.; Xie, P.; Sun, Y.Z.; Yu, R.T. Selective deletion of apolipoprotein E in astrocytes ameliorates the spatial learning and memory deficits in Alzheimer's disease (APP/PS1) mice by inhibiting TGF-beta/Smad2/STAT3 signaling. Neurobiol. Aging 2017, 54, 112-132. [CrossRef] [PubMed]

554. Fan, Q.; He, W.; Gayen, M.; Benoit, M.R.; Luo, X.; Hu, X.; Yan, R. Activated CX3CL1/Smad2 Signals Prevent Neuronal Loss and Alzheimer's Tau Pathology-Mediated Cognitive Dysfunction. J. Neurosci. 2020, 40, 1133-1144. [CrossRef] [PubMed]

555. Baig, S.; van Helmond, Z.; Love, S. Tau hyperphosphorylation affects Smad 2/3 translocation. Neuroscience 2009, 163, 561-570. [CrossRef] [PubMed]

556. Anderson, P.; Kedersha, N. Stress granules: The Tao of RNA triage. Trends Biochem. Sci. 2008, 33, 141-150. [CrossRef]

557. Liu-Yesucevitz, L.; Bassell, G.J.; Gitler, A.D.; Hart, A.C.; Klann, E.; Richter, J.D.; Warren, S.T.; Wolozin, B. Local RNA translation at the synapse and in disease. J. Neurosci. 2011, 31, 16086-16093. [CrossRef]

558. Bai, B.; Hales, C.M.; Chen, P.C.; Gozal, Y.; Dammer, E.B.; Fritz, J.J.; Wang, X.; Xia, Q.; Duong, D.M.; Street, C.; et al. U1 small nuclear ribonucleoprotein complex and RNA splicing alterations in Alzheimer's disease. Proc. Natl. Acad. Sci. USA 2013, 110, 16562-16567. [CrossRef]

559. Berson, A.; Barbash, S.; Shaltiel, G.; Goll, Y.; Hanin, G.; Greenberg, D.S.; Ketzef, M.; Becker, A.J.; Friedman, A.; Soreq, H. Cholinergic-associated loss of hnRNP-A/B in Alzheimer's disease impairs cortical splicing and cognitive function in mice. EMBO Mol. Med. 2012, 4, 730-742. [CrossRef]

560. Bishof, I.; Dammer, E.B.; Duong, D.M.; Kundinger, S.R.; Gearing, M.; Lah, J.J.; Levey, A.I.; Seyfried, N.T. RNA-binding proteins with basic-acidic dipeptide (BAD) domains self-assemble and aggregate in Alzheimer's disease. J. Biol. Chem. 2018, 293, 11047-11066. [CrossRef]

561. Vanderweyde, T.; Apicco, D.J.; Youmans-Kidder, K.; Ash, P.E.A.; Cook, C.; Lummertz da Rocha, E.; Jansen-West, K.; Frame, A.A.; Citro, A.; Leszyk, J.D.; et al. Interaction of tau with the RNA-Binding Protein TIA1 Regulates tau Pathophysiology and Toxicity. Cell Rep. 2016, 15, 1455-1466. [CrossRef] 
562. Pomeranz Krummel, D.A.; Oubridge, C.; Leung, A.K.; Li, J.; Nagai, K. Crystal structure of human spliceosomal U1 snRNP at 5.5 A resolution. Nature 2009, 458, 475-480. [CrossRef]

563. Bai, B.; Chen, P.C.; Hales, C.M.; Wu, Z.; Pagala, V.; High, A.A.; Levey, A.I.; Lah, J.J.; Peng, J. Integrated approaches for analyzing U1-70K cleavage in Alzheimer's disease. J. Proteome Res. 2014, 13, 4526-4534. [CrossRef] [PubMed]

564. Diner, I.; Hales, C.M.; Bishof, I.; Rabenold, L.; Duong, D.M.; Yi, H.; Laur, O.; Gearing, M.; Troncoso, J.; Thambisetty, M.; et al Aggregation properties of the small nuclear ribonucleoprotein U1-70K in Alzheimer disease. J. Biol. Chem. 2014, 289, 35296-35313. [CrossRef] [PubMed]

565. Raj, T.; Li, Y.I.; Wong, G.; Humphrey, J.; Wang, M.; Ramdhani, S.; Wang, Y.C.; Ng, B.; Gupta, I.; Haroutunian, V.; et al. Integrative transcriptome analyses of the aging brain implicate altered splicing in Alzheimer's disease susceptibility. Nat. Genet. 2018, 50, 1584-1592. [CrossRef] [PubMed]

566. Del Gatto-Konczak, F.; Bourgeois, C.F.; Le Guiner, C.; Kister, L.; Gesnel, M.-C.; Stévenin, J.; Breathnach, R. The RNA-binding protein TIA-1 is a novel mammalian splicing regulator acting through intron sequences adjacent to a $5^{\prime}$ splice site. Mol. Cell. Biol. 2000, 20, 6287-6299. [CrossRef] [PubMed]

567. Gilks, N.; Kedersha, N.; Ayodele, M.; Shen, L.; Stoecklin, G.; Dember, L.M.; Anderson, P. Stress granule assembly is mediated by prion-like aggregation of TIA-1. Mol. Biol. Cell 2004, 15, 5383-5398. [CrossRef]

568. Vanderweyde, T.; Yu, H.; Varnum, M.; Liu-Yesucevitz, L.; Citro, A.; Ikezu, T.; Duff, K.; Wolozin, B. Contrasting pathology of the stress granule proteins TIA-1 and G3BP in tauopathies. J. Neurosci. 2012, 32, 8270-8283. [CrossRef] [PubMed]

569. Jiang, L.; Ash, P.E.A.; Maziuk, B.F.; Ballance, H.I.; Boudeau, S.; Abdullatif, A.A.; Orlando, M.; Petrucelli, L.; Ikezu, T.; Wolozin, B. TIA1 regulates the generation and response to toxic tau oligomers. Acta Neuropathol. 2019, 137, 259-277. [CrossRef]

570. Apicco, D.J.; Ash, P.E.A.; Maziuk, B.; LeBlang, C.; Medalla, M.; Al Abdullatif, A.; Ferragud, A.; Botelho, E.; Ballance, H.I.; Dhawan, U.; et al. Reducing the RNA binding protein TIA1 protects against tau-mediated neurodegeneration in vivo. Nat. Neurosci. 2018, 21, 72-80. [CrossRef]

571. McKerracher, L.; Chamoux, M.; Arregui, C.O. Role of laminin and integrin interactions in growth cone guidance. Mol. Neurobiol. 1996, 12, 95-116. [CrossRef]

572. Teng, F.Y.; Tang, B.L. Axonal regeneration in adult CNS neurons-signaling molecules and pathways. J. Neurochem. 2006, 96, 1501-1508. [CrossRef]

573. McKenna, N.J.; O'Malley, B.W. Combinatorial control of gene expression by nuclear receptors and coregulators. Cell 2002, 108, 465-474. [CrossRef]

574. Ochsner, S.A.; Abraham, D.; Martin, K.; Ding, W.; McOwiti, A.; Kankanamge, W.; Wang, Z.; Andreano, K.; Hamilton, R.A.; Chen, Y.; et al. The Signaling Pathways Project, an integrated 'omics knowledgebase for mammalian cellular signaling pathways. Sci. Data 2019, 6, 252. [CrossRef] [PubMed]

575. Mielke, K.; Herdegen, T. JNK and p38 stresskinases-Degenerative effectors of signal-transduction-cascades in the nervous system. Prog. Neurobiol. 2000, 61, 45-60. [CrossRef]

576. Berridge, M.J. Calcium hypothesis of Alzheimer's disease. Pflug. Arch. 2010, 459, 441-449. [CrossRef]

577. Cau, Y.; Valensin, D.; Mori, M.; Draghi, S.; Botta, M. Structure, function, involvement in diseases and targeting of 14-3-3 proteins: An update. Curr. Med. Chem. 2018, 25, 5-21. [CrossRef] [PubMed]

578. Cornell, B.; Toyo-Oka, K. 14-3-3 proteins in brain development: Neurogenesis, neuronal migration and neuromorphogenesis. Front. Mol. Neurosci. 2017, 10, 318. [CrossRef]

579. Foote, M.; Zhou, Y. 14-3-3 proteins in neurological disorders. Int. J. Biochem. Mol. Biol. 2012, 3, 152.

580. Agarwal-Mawal, A.; Qureshi, H.Y.; Cafferty, P.W.; Yuan, Z.; Han, D.; Lin, R.; Paudel, H.K. 14-3-3 connects glycogen synthase kinase-3 beta to tau within a brain microtubule-associated tau phosphorylation complex. J. Biol. Chem. 2003, 278, 12722-12728. [CrossRef] [PubMed]

581. Sadik, G.; Tanaka, T.; Kato, K.; Yamamori, H.; Nessa, B.N.; Morihara, T.; Takeda, M. Phosphorylation of tau at Ser214 mediates its interaction with 14-3-3 protein: Implications for the mechanism of tau aggregation. J. Neurochem. 2009, 108, 33-43. [CrossRef]

582. Rosenquist, M. 14-3-3 proteins in apoptosis. Braz. J. Med. Biol. Res. 2003, 36, 403-408. [CrossRef]

583. Jang, S.W.; Liu, X.; Fu, H.; Rees, H.; Yepes, M.; Levey, A.; Ye, K. Interaction of Akt-phosphorylated SRPK2 with 14-3-3 mediates cell cycle and cell death in neurons. J. Biol. Chem. 2009, 284, 24512-24525. [CrossRef] [PubMed]

584. Chen, Y.; Chen, X.; Yao, Z.; Shi, Y.; Xiong, J.; Zhou, J.; Su, Z.; Huang, Y. 14-3-3/Tau interaction and Tau amyloidogenesis. J. Mol. Neurosci. 2019, 68, 620-630. [CrossRef]

585. McShea, A.; Zelasko, D.A.; Gerst, J.L.; Smith, M.A. Signal transduction abnormalities in Alzheimer's disease: Evidence of a pathogenic stimuli. Brain Res. 1999, 815, 237-242. [CrossRef]

586. Venezia, V.; Russo, C.; Repetto, E.; Salis, S.; Dolcini, V.; Genova, F.; Nizzari, M.; Mueller, U.; Schettini, G. Apoptotic cell death influences the signaling activity of the amyloid precursor protein through ShcA and Grb2 adaptor proteins in neuroblastoma SH-SY5Y cells. J. Neurochem. 2004, 90, 1359-1370. [CrossRef]

587. Roder, H.M.; Eden, P.A.; Ingram, V.M. Brain protein kinase PK40erk converts TAU into a PHF-like form as found in Alzheimer's disease. Biochem. Biophys. Res. Commun. 1993, 193, 639-647. [CrossRef]

588. Uhlén, M.; Fagerberg, L.; Hallström, B.M.; Lindskog, C.; Oksvold, P.; Mardinoglu, A.; Sivertsson, Å.; Kampf, C.; Sjöstedt, E.; Asplund, A. Tissue-based map of the human proteome. Science 2015, 347, 1260419. [CrossRef] 
589. O'Brien, J.S.; Carson, G.S.; Seo, H.-C.; Hiraiwa, M.; Kishimoto, Y. Identification of prosaposin as a neurotrophic factor. Proc. Natl. Acad. Sci. USA 1994, 91, 9593-9596. [CrossRef] [PubMed]

590. Coleman, J.L.; Ngo, T.; Schmidt, J.; Mrad, N.; Liew, C.K.; Jones, N.M.; Graham, R.M.; Smith, N.J. Metalloprotease cleavage of the $\mathrm{N}$ terminus of the orphan $\mathrm{G}$ protein-coupled receptor GPR37L1 reduces its constitutive activity. Sci. Signal. 2016, 9, ra36. [CrossRef]

591. Vaz-Silva, J.; Gomes, P.; Jin, Q.; Zhu, M.; Zhuravleva, V.; Quintremil, S.; Meira, T.; Silva, J.; Dioli, C.; Soares-Cunha, C.; et al. Endolysosomal degradation of Tau and its role in glucocorticoid-driven hippocampal malfunction. EMBO J. 2018, 37 , e99084. [CrossRef] [PubMed]

592. Raiborg, C.; Stenmark, H. The ESCRT machinery in endosomal sorting of ubiquitylated membrane proteins. Nature 2009, 458, 445-452. [CrossRef] [PubMed]

593. Sheehan, P.; Zhu, M.; Beskow, A.; Vollmer, C.; Waites, C.L. Activity-Dependent Degradation of Synaptic Vesicle Proteins Requires Rab35 and the ESCRT Pathway. J. Neurosci. 2016, 36, 8668-8686. [CrossRef] [PubMed]

594. Nixon, R.A.; Yang, D.-S. Autophagy failure in Alzheimer's disease-Locating the primary defect. Neurobiol. Dis. $2011,43,38-45$. [CrossRef]

595. Green, K.N.; Billings, L.M.; Roozendaal, B.; McGaugh, J.L.; LaFerla, F.M. Glucocorticoids increase amyloid- $\beta$ and tau pathology in a mouse model of Alzheimer's disease. J. Neurosci. 2006, 26, 9047-9056. [CrossRef]

596. Gireud-Goss, M.; Reyes, S.; Tewari, R.; Patrizz, A.; Howe, M.D.; Kofler, J.; Waxham, M.N.; McCullough, L.D.; Bean, A.J. The ubiquitin ligase UBE4B regulates amyloid precursor protein ubiquitination, endosomal trafficking, and amyloid $\beta 42$ generation and secretion. Mol. Cell. Neurosci. 2020, 108, 103542. [CrossRef]

597. Ittner, L.M.; Ke, Y.D.; Gotz, J. Phosphorylated Tau interacts with c-Jun N-terminal kinase-interacting protein 1 (JIP1) in Alzheimer disease. J. Biol. Chem. 2009, 284, 20909-20916. [CrossRef]

598. Ozdemir, A.Y.; Rom, I.; Kovalevich, J.; Yen, W.; Adiga, R.; Dave, R.S.; Langford, D. PINCH in the cellular stress response to tau-hyperphosphorylation. PLoS ONE 2013, 8, e58232. [CrossRef]

599. Li, S.; Bordoy, R.; Stanchi, F.; Moser, M.; Braun, A.; Kudlacek, O.; Wewer, U.M.; Yurchenco, P.D.; Fassler, R. PINCH1 regulates cell-matrix and cell-cell adhesions, cell polarity and cell survival during the peri-implantation stage. J. Cell Sci. 2005, 118 Pt 13, 2913-2921. [CrossRef]

600. Rearden, A.; Hurford, R.; Luu, N.; Kieu, E.; Sandoval, M.; Perez-Liz, G.; Del Valle, L.; Powell, H.; Langford, T.D. Novel expression of PINCH in the central nervous system and its potential as a biomarker for human immunodeficiency virus-associated neurodegeneration. J. Neurosci. Res. 2008, 86, 2535-2542. [CrossRef]

601. Jang, H.J.; Yang, Y.R.; Kim, J.K.; Choi, J.H.; Seo, Y.K.; Lee, Y.H.; Lee, J.E.; Ryu, S.H.; Suh, P.G. Phospholipase C-gamma1 involved in brain disorders. Adv. Biol. Regu.l 2013, 53, 51-62. [CrossRef] [PubMed]

602. Kang, D.-S.; Kim, I.S.; Baik, J.-H.; Kim, D.; Cocco, L.; Suh, P.-G. The function of PLC $\gamma 1$ in developing mouse mDA system. Adv. Biol. Regul. 2020, 75, 100654. [CrossRef] [PubMed]

603. Hayashi, H.; Campenot, R.B.; Vance, D.E.; Vance, J.E. Protection of neurons from apoptosis by apolipoprotein E-containing lipoproteins does not require lipoprotein uptake and involves activation of phospholipase Cgamma1 and inhibition of calcineurin. J. Biol. Chem. 2009, 284, 29605-29613. [CrossRef] [PubMed]

604. Shimohama, S.; Matsushima, H.; Fujimoto, S.; Takenawa, T.; Taniguchi, T.; Kameyama, M.; Kimura, J. Differential involvement of phospholipase C isozymes in Alzheimer's disease. Gerontology 1995, 41 (Suppl. 1), 13-19. [CrossRef]

605. Hampel, H.; Ewers, M.; Bürger, K.; Annas, P.; Mörtberg, A.; Bogstedt, A.; Frölich, L.; Schröder, J.; Schönknecht, P.; Riepe, M.W. Lithium trial in Alzheimer's disease: A randomized, single-blind, placebo-controlled, multicenter 10-week study. J. Clin. Psychiatry 2009, 70, 922-931. [CrossRef]

606. Pagan, F.; Hebron, M.; Valadez, E.H.; Torres-Yaghi, Y.; Huang, X.; Mills, R.R.; Wilmarth, B.M.; Howard, H.; Dunn, C.; Carlson, A. Nilotinib effects in Parkinson's disease and dementia with Lewy bodies. J. Parkinson's Dis. 2016, 6, 503-517. [CrossRef]

607. Nygaard, H.B.; Wagner, A.F.; Bowen, G.S.; Good, S.P.; MacAvoy, M.G.; Strittmatter, K.A.; Kaufman, A.C.; Rosenberg, B.J.; Sekine-Konno, T.; Varma, P. A phase Ib multiple ascending dose study of the safety, tolerability, and central nervous system availability of AZD0530 (saracatinib) in Alzheimer's disease. Alzheimer's Res. Ther. 2015, 7, 1-11. [CrossRef] [PubMed]

608. Van Dyck, C.H.; Nygaard, H.B.; Chen, K.; Donohue, M.C.; Raman, R.; Rissman, R.A.; Brewer, J.B.; Koeppe, R.A.; Chow, T.W.; Rafii, M.S. Effect of AZD0530 on cerebral metabolic decline in Alzheimer disease: A randomized clinical trial. JAMA Neurol. 2019, 76, 1219-1229. [CrossRef] [PubMed]

609. Del Ser, T.; Steinwachs, K.C.; Gertz, H.J.; Andres, M.V.; Gomez-Carrillo, B.; Medina, M.; Vericat, J.A.; Redondo, P.; Fleet, D.; Leon, T. Treatment of Alzheimer's disease with the GSK-3 inhibitor tideglusib: A pilot study. J. Alzheimer's Dis. 2013, 33, $205-215$. [CrossRef]

610. Lovestone, S.; Boada, M.; Dubois, B.; Hüll, M.; Rinne, J.O.; Huppertz, H.-J.; Calero, M.; Andres, M.V.; Gómez-Carrillo, B.; Leon, T. A phase II trial of tideglusib in Alzheimer's disease. J. Alzheimer's Dis. 2015, 45, 75-88. [CrossRef] [PubMed]

611. Tolosa, E.; Litvan, I.; Höglinger, G.U.; Burn, D.; Lees, A.; Andrés, M.V.; Gómez-Carrillo, B.; León, T.; Del Ser, T.; Investigators, T. A phase 2 trial of the GSK-3 inhibitor tideglusib in progressive supranuclear palsy. Mov. Disord. 2014, 29, 470-478. [CrossRef] [PubMed] 
612. Höglinger, G.U.; Huppertz, H.J.; Wagenpfeil, S.; Andrés, M.V.; Belloch, V.; León, T.; Del Ser, T.; Investigators, T.M.; Gmez, J.; Tijero, B. Tideglusib reduces progression of brain atrophy in progressive supranuclear palsy in a randomized trial. Mov. Disord. 2014, 29, 479-487. [CrossRef] [PubMed]

613. Tariot, P.N.; Schneider, L.S.; Cummings, J.; Thomas, R.G.; Raman, R.; Jakimovich, L.J.; Loy, R.; Bartocci, B.; Fleisher, A.; Ismail, M.S. Chronic divalproex sodium to attenuate agitation and clinical progression of Alzheimer disease. Arch. Gen. Psychiatry 2011, 68, 853-861. [CrossRef]

614. Leclair-Visonneau, L.; Rouaud, T.; Debilly, B.; Durif, F.; Houeto, J.-L.; Kreisler, A.; Defebvre, L.; Lamy, E.; Volteau, C.; Nguyen, J.-M. Randomized placebo-controlled trial of sodium valproate in progressive supranuclear palsy. Clin. Neurol. Neurosurg. 2016, 146, 35-39. [CrossRef]

615. Fleisher, A.; Truran, D.; Mai, J.; Langbaum, J.; Aisen, P.; Cummings, J.; Jack, C.; Weiner, M.; Thomas, R.; Schneider, L. Chronic divalproex sodium use and brain atrophy in Alzheimer disease. Neurology 2011, 77, 1263-1271. [CrossRef]

616. Huisa, B.N.; Thomas, R.G.; Jin, S.; Oltersdorf, T.; Taylor, C.; Feldman, H.H. Memantine and acetylcholinesterase inhibitor use in Alzheimer's disease clinical trials: Potential for confounding by indication. J. Alzheimer's Dis. 2019, 67, 707-713. [CrossRef]

617. Malpas, C.B.; Vivash, L.; Genc, S.; Saling, M.M.; Desmond, P.; Steward, C.; Hicks, R.J.; Callahan, J.; Brodtmann, A.; Collins, S. A phase IIa randomized control trial of VEL015 (Sodium Selenate) in mild-moderate Alzheimer's disease. J. Alzheimer's Dis. 2016, 54, 223-232. [CrossRef]

618. VandeVrede, L.; Dale, M.L.; Fields, S.; Frank, M.; Hare, E.; Heuer, H.W.; Keith, K.; Koestler, M.; Ljubenkov, P.A.; McDermott, D. Open-Label Phase 1 Futility Studies of Salsalate and Young Plasma in Progressive Supranuclear Palsy. Mov. Disord. Clin. Pract. 2020, 7, 440-447. [CrossRef]

619. Peng, Y.; Hu, Y.; Xu, S.; Li, P.; Li, J.; Lu, L.; Yang, H.; Feng, N.; Wang, L.; Wang, X. L-3-n-butylphthalide reduces tau phosphorylation and improves cognitive deficits in A $\beta$ PP/PS1-Alzheimer's transgenic mice. J. Alzheimer's Dis. 2012, 29, 379-391. [CrossRef]

620. Rohn, T.T.; Kokoulina, P.; Eaton, C.R.; Poon, W.W. Caspase activation in transgenic mice with Alzheimer-like pathology: Results from a pilot study utilizing the caspase inhibitor, Q-VD-OPh. Int. J. Clin. Exp. Med. 2009, 2, 300.

621. Flores, J.; Noël, A.; Foveau, B.; Beauchet, O.; LeBlanc, A.C. Pre-symptomatic Caspase-1 inhibitor delays cognitive decline in a mouse model of Alzheimer disease and aging. Nat. Commun. 2020, 11, 1-14. [CrossRef]

622. Flores, J.; Noël, A.; Foveau, B.; Lynham, J.; Lecrux, C.; LeBlanc, A.C. Caspase-1 inhibition alleviates cognitive impairment and neuropathology in an Alzheimer's disease mouse model. Nat. Commun. 2018, 9, 1-14. [CrossRef]

623. Selenica, M.-L.; Benner, L.; Housley, S.B.; Manchec, B.; Lee, D.C.; Nash, K.R.; Kalin, J.; Bergman, J.A.; Kozikowski, A.; Gordon, M.N. Histone deacetylase 6 inhibition improves memory and reduces total tau levels in a mouse model of tau deposition. Alzheimer's Res. Ther. 2014, 6, 1-12. [CrossRef] [PubMed]

624. Fan, S.-J.; Huang, F.-I.; Liou, J.-P.; Yang, C.-R. The novel histone de acetylase 6 inhibitor, MPT0G211, ameliorates tau phosphorylation and cognitive deficits in an Alzheimer's disease model. Cell Death Dis. 2018, 9, 1-14. [CrossRef] [PubMed]

625. Lee, H.-Y.; Fan, S.-J.; Huang, F.-I.; Chao, H.-Y.; Hsu, K.-C.; Lin, T.E.; Yeh, T.-K.; Lai, M.-J.; Li, Y.-H.; Huang, H.-L. 5-Aroylindoles act as selective histone deacetylase 6 inhibitors ameliorating Alzheimer's disease phenotypes. J. Med. Chem. 2018, 61, 7087-7102. [CrossRef] [PubMed]

626. Onishi, T.; Maeda, R.; Terada, M.; Sato, S.; Fujii, T.; Ito, M.; Hashikami, K.; Kawamoto, T.; Tanaka, M. A novel orally active HDAC6 inhibitor T-518 shows a therapeutic potential for Alzheimer's disease and tauopathy in mice. Sci. Rep. 2021, 11, 1-11. [CrossRef]

627. Dickey, C.A.; Kamal, A.; Lundgren, K.; Klosak, N.; Bailey, R.M.; Dunmore, J.; Ash, P.; Shoraka, S.; Zlatkovic, J.; Eckman, C.B. The high-affinity HSP90-CHIP complex recognizes and selectively degrades phosphorylated tau client proteins. J. Clin. Investig. 2007, 117, 648-658. [CrossRef] [PubMed]

628. Miyata, Y.; Li, X.; Lee, H.-F.; Jinwal, U.K.; Srinivasan, S.R.; Seguin, S.P.; Young, Z.T.; Brodsky, J.L.; Dickey, C.A.; Sun, D. Synthesis and initial evaluation of YM-08, a blood-brain barrier permeable derivative of the heat shock protein 70 (Hsp70) inhibitor MKT-077, which reduces tau levels. ACS Chem. Neurosci. 2013, 4, 930-939. [CrossRef] [PubMed]

629. Abisambra, J.; Jinwal, U.K.; Miyata, Y.; Rogers, J.; Blair, L.; Li, X.; Seguin, S.P.; Wang, L.; Jin, Y.; Bacon, J. Allosteric heat shock protein 70 inhibitors rapidly rescue synaptic plasticity deficits by reducing aberrant tau. Biol. Psychiatry 2013, 74, 367-374 [CrossRef]

630. Hardy, J.A.; Higgins, G.A. Alzheimer's disease: The amyloid cascade hypothesis. Science 1992, 256, 184-186. [CrossRef]

631. Selkoe, D.J.; Hardy, J. The amyloid hypothesis of Alzheimer's disease at 25 years. EMBO Mol. Med. 2016, 8, 595-608. [CrossRef]

632. van der Kant, R.; Langness, V.F.; Herrera, C.M.; Williams, D.A.; Fong, L.K.; Leestemaker, Y.; Steenvoorden, E.; Rynearson, K.D.; Brouwers, J.F.; Helms, J.B. Cholesterol metabolism is a druggable axis that independently regulates tau and amyloid- $\beta$ in iPSC-derived Alzheimer's disease neurons. Cell Stem Cell 2019, 24, 363-375.e9. [CrossRef]

633. Young, J.E.; Fong, L.K.; Frankowski, H.; Petsko, G.A.; Small, S.A.; Goldstein, L.S. Stabilizing the retromer complex in a human stem cell model of Alzheimer's disease reduces TAU phosphorylation independently of amyloid precursor protein. Stem Cell Rep. 2018, 10, 1046-1058. [CrossRef] [PubMed]

634. Bhaskar, K.; Konerth, M.; Kokiko-Cochran, O.N.; Cardona, A.; Ransohoff, R.M.; Lamb, B.T. Regulation of tau pathology by the microglial fractalkine receptor. Neuron 2010, 68, 19-31. [CrossRef] [PubMed]

635. Johnson, K.A.; Schultz, A.; Betensky, R.A.; Becker, J.A.; Sepulcre, J.; Rentz, D.; Mormino, E.; Chhatwal, J.; Amariglio, R.; Papp, K. Tau positron emission tomographic imaging in aging and early A lzheimer disease. Ann. Neurol. 2016, 79, 110-119. [CrossRef] [PubMed] 
636. Schöll, M.; Lockhart, S.N.; Schonhaut, D.R.; O’Neil, J.P.; Janabi, M.; Ossenkoppele, R.; Baker, S.L.; Vogel, J.W.; Faria, J.; Schwimmer, H.D. PET imaging of tau deposition in the aging human brain. Neuron 2016, 89, 971-982. [CrossRef]

637. Grothe, M.J.; Barthel, H.; Sepulcre, J.; Dyrba, M.; Sabri, O.; Teipel, S.J. Alzheimer's Disease Neuroimaging Initiative. In vivo staging of regional amyloid deposition. Neurology 2017, 89, 2031-2038. [CrossRef]

638. Jansen, W.J.; Ossenkoppele, R.; Knol, D.L.; Tijms, B.M.; Scheltens, P.; Verhey, F.R.; Visser, P.J.; Aalten, P.; Aarsland, D.; Alcolea, D Prevalence of cerebral amyloid pathology in persons without dementia: A meta-analysis. JAMA 2015, 313, 1924-1938. [CrossRef]

639. Gonzalez, M.W.; Kann, M.G. Chapter 4: Protein interactions and disease. PLoS Comput. Biol. 2012, 8, e1002819. [CrossRef]

640. Morris, M.; Maeda, S.; Vossel, K.; Mucke, L. The many faces of tau. Neuron 2011, 70, 410-426. [CrossRef] 